Subscriber access provided by Caltech Library

\title{
Article
}

\section{Unified Enantioselective, Convergent Synthetic Approach Toward the Furanobutenolide-Derived Polycyclic Norcembranoid Diterpenes: Synthesis of a Series of Ineleganoloids by Oxidation State Manipulation of the Carbocyclic Core}

Robert A. Craig, Russell C Smith, Jennifer L. Roizen, Amanda C Jones, Scott C Virgil, and Brian M. Stoltz J. Org. Chem., Just Accepted Manuscript • DOI: 10.1021/acs.joc.9b00635 • Publication Date (Web): 08 May 2019

Downloaded from http://pubs.acs.org on May 8, 2019

\section{Just Accepted}

"Just Accepted" manuscripts have been peer-reviewed and accepted for publication. They are posted online prior to technical editing, formatting for publication and author proofing. The American Chemical Society provides "Just Accepted" as a service to the research community to expedite the dissemination of scientific material as soon as possible after acceptance. "Just Accepted" manuscripts appear in full in PDF format accompanied by an HTML abstract. "Just Accepted" manuscripts have been fully peer reviewed, but should not be considered the official version of record. They are citable by the Digital Object Identifier (DOI®). "Just Accepted" is an optional service offered to authors. Therefore, the "Just Accepted" Web site may not include all articles that will be published in the journal. After a manuscript is technically edited and formatted, it will be removed from the "Just Accepted" Web site and published as an ASAP article. Note that technical editing may introduce minor changes to the manuscript text and/or graphics which could affect content, and all legal disclaimers and ethical guidelines that apply to the journal pertain. ACS cannot be held responsible for errors or consequences arising from the use of information contained in these "Just Accepted" manuscripts. 


\section{INTRODUCTION}

Natural products have proven invaluable for the development of pharmaceuticals, providing inspiration and serving as lead compounds for the treatment of ailments from cancer ${ }^{1}$ to bacterial infection ${ }^{1 \mathrm{c}, \mathrm{d}, 2}$ and neurological diseases. ${ }^{1 \mathrm{a}, \mathrm{c}, 3}$ Additionally, through target-directed synthesis, natural products continue to inspire the development of novel reaction manifolds and the extension of chemical space. ${ }^{4}$ The furanobutenolide-derived norcembranoid diterpenes are a class of biologically active natural products that have been sparsely explored and offer tremendous potential for both pharmaceutical and methodological development. ${ }^{5}$ Among the members of this natural product family, ineleganolide (1) stands out due to the intricate functionalization of the compact and highly oxygenated structure paired with known antileukemic properties (Figure 1). ${ }^{5 f, 6}$ Since the initial isolation and assignment of the structure in 1999 from the namesake soft coral Sinularia inelegans ${ }^{6 j}$ ineleganolide (1) has been isolated from a number of other species belonging to the same genus ${ }^{6 a-i}$ along with the isomeric natural products horiolide (2) ${ }^{7}$ and kavaranolide (3). ${ }^{6 \mathrm{c}}$

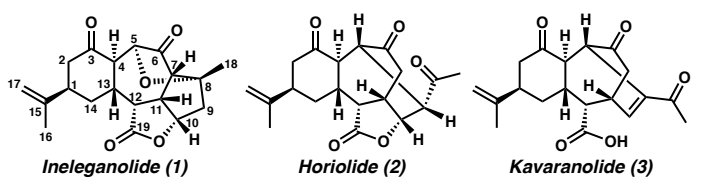

Figure 1. Ineleganolide (1) and Isomeric [6,7]-Polycyclic Furanobutenolide-Derived Norcembranoid Diterpenes.

Ineleganolide (1) poses a number of formidable synthetic challenges, ${ }^{8,9}$ highlighted by nine stereogenic centers distribut- ed across $[6,7,5]$-carbocyclic scaffold that is constrained within a highly cupped configuration by a bridging dihydrofuranone. Previously, we developed an enantioselective and diastereoselective approach toward the synthesis of the furanobutenolide-derived polycyclic norditerpenoids, resulting in synthetic access to the enantioenriched [6,7,5,5]-tetracyclic core of ent-ineleganolide (ent-1) and representing the first completion of the carbocyclic scaffold of any member of the polycyclic furanobutenolide-derived norcembranoid natural product family (Scheme 1). ${ }^{10,11}$ Completion of entineleganolide (ent-1) from ent-epi-isoineleganolide B (6), envisioned through olefin isomerization and ultimately intramolecular oxa-Michael addition from vinylogous diketone 7 , proved untenable. ${ }^{12}$ Nevertheless, with synthetic access to the [6,7,5,5]-tetracyclic core of ent-ineleganolide (ent-1) established, we sought to develop an alternative late-stage strategy that would enable access to the natural product itself. Presented herein are our efforts toward this end and, although ultimately proven unable to provide ineleganolide, have lead to a number of additional ineleganoloids that have been prepared through intriguing and unusual chemistry. 
Scheme 1. Enantioselective Formation of the $[6,7,5,5]-$ Tetracyclic Core of ent-Ineleganolide (ent-1)
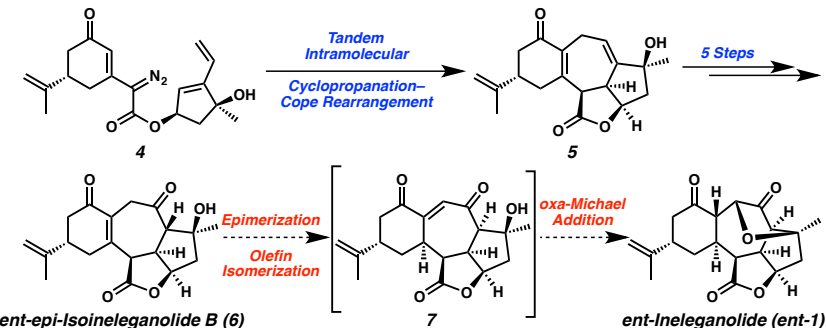

\section{RESULTS AND DISCUSSION}

Alternative access to ent-ineleganolide (ent-1) was envisioned through two distinct strategies. Firstly, from synthetic intermediate diene 5, ent-ineleganolide (ent-1) could be synthesized using a sequential reduction-oxidation strategy (Scheme 2A). Conjugate reduction of the enone moiety within diene 5 would provide $2 \mathrm{H}$-ent-ineleganolide (8) after oxidation of the remaining cycloheptenyl olefin. Completion of entineleganolide (ent-1) from $2 H$-ent-ineleganolide (8) would only require the formation of the final $\mathrm{C}-\mathrm{O}$ bond and the bridging dihydrofuranone ring. This oxidative annulation could be accomplished either directly by oxidation of a $\mathrm{C}-\mathrm{H}$ bond at the apical methylene or stepwise by an oxidative desaturation and ultimately an intramolecular oxa-Michael addition.

Contrastingly, ent-ineleganolide (ent-1) might be synthesized from ketopyran 9 by an antipodal approach (Scheme 2B). In this approach, ketopyran 9 would undergo oxidation of the central cycloheptanone to install a transannular vinylogous diketone and furnish dihydropyranone 10. Subsequently, a chemoselective reduction of the $\alpha$-alkoxyketone $\mathrm{C}-\mathrm{O}$ bond within dihydropyranone $\mathbf{1 0}$ in the presence of the unsaturated system would lead to spontaneous formation of the dihydrofuranone ring by intramolecular oxa-Michael addition and leave only a deoxygenation or a sequential dehydrationreduction to complete the natural product (ent-1).

Scheme 2. Alternative Synthetic Strategies for the Completion of ent-Ineleganolide (ent-1)
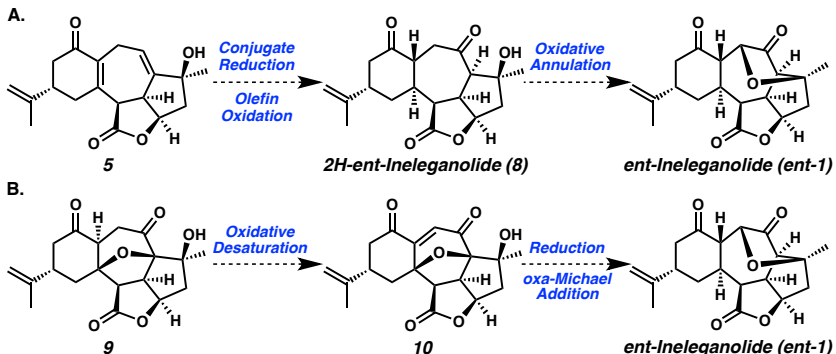

Late-stage synthetic efforts toward ent-ineleganolide (ent1) began with the sequential reduction-oxidation strategy from tetracyclic diene 5. Retrosynthetically, access to entineleganolide (ent-1) was envisioned from vinylogous diketone 7, furnishing the natural product following an intramolecular oxa-Michael addition (Scheme 3). Rather than accessing vinylogous diketone 7 by olefin isomerization from ent-isoineleganolide B (6, see Scheme 1), enedione 7 would be synthesized by the oxidation of saturated 1,4-diketone 8. Alternatively, ent-ineleganolide (ent-1) could be formed directly from $2 H$-ent-ineleganolide (8) through intramolecular oxida- tive annulation by $\mathrm{C}-\mathrm{H}$ functionalization. $2 \mathrm{H}$-entIneleganolide (8) would be prepared from epoxide 11 by a syn-facial 1,2-hydride shift. Saturated ketone 11 would be synthesized by the sequential conjugate reduction and hydroxyl-directed epoxidation from diene $\mathbf{5}$.

Scheme 3. Retrosynthetic Analysis of ent-Ineleganolide (ent-1) Employing Late-Stage Oxidation

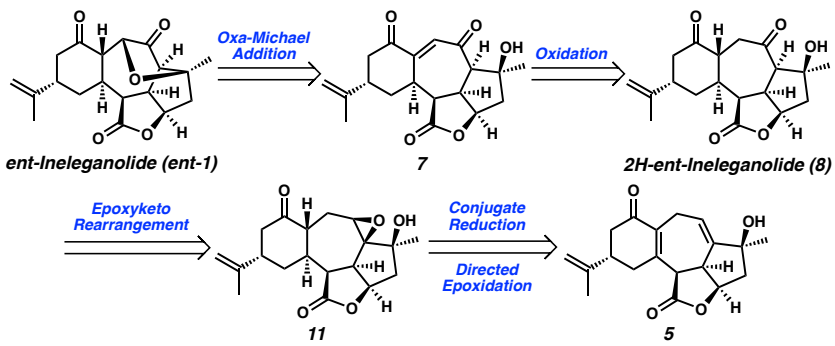

The conjugate reduction of the tetrasubstituted enone moiety within tetracyclic diene $\mathbf{5}$ proved nontrivial. All attempts to reduce the conjugated system by the nucleophilic addition of hydride failed, likely due to the steric environment surrounding the fully-substituted $\beta$-position. Alternatively, we were pleased to discover the use of samarium diiodide $\left(\mathrm{SmI}_{2}\right)$ was a suitable reductant to enable the formation of saturated ketone 12 as a single diastereomer (Scheme 4). The use of water as an additive in an optimal ratio proved crucial for this transformation. The absence of an additive or the addition of $\mathrm{MeOH}, t-\mathrm{BuOH}, \mathrm{LiCl}$, or fewer equivalents of $\mathrm{H}_{2} \mathrm{O}$ prevented the complete consumption of starting material. Contrastingly, the addition of HMPA or the use of additional equivalents of $\mathrm{H}_{2} \mathrm{O}$ resulted in diminished yield of tetracycle $\mathbf{1 2}$ through erosion of diastereoselectivity paired with over-reduction of the desired ketone product (12).

\section{Scheme 4. Conjugate Reduction of Diene 5}
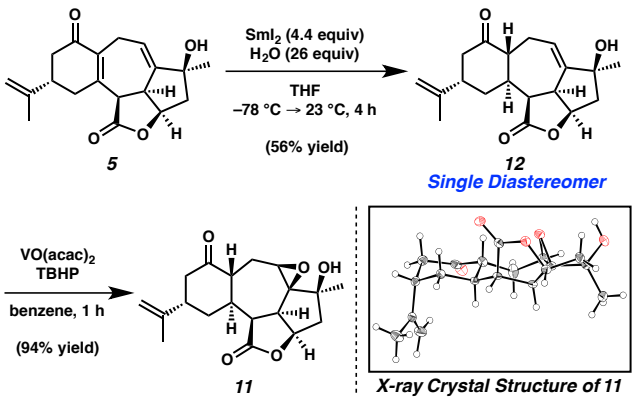

The hydroxyl-directed epoxidation of cycloheptene 12 was then accomplished under vanadium-catalyzed conditions to provide epoxide 11 in 94\% yield. Epoxide 11 proved to be a crystalline white solid, enabling the unambiguous determination of relative configuration by single-crystal X-ray diffraction. This crystal structure confirmed not only the assignment of the epoxide, being correctly directed to the $\beta$-face of the molecule, but also the configuration of the trans-fusion at the [6,7]-ring junction, matching that found in ent-ineleganolide (ent-1, see Scheme 3).

Similar to our experiences with a related epoxide, ${ }^{11}$ advancement of epoxide 11 to $2 \mathrm{H}$-ent-ineleganolide (8) through an epoxide rearrangement proved unfruitful under a variety of Lewis acidic conditions (Scheme 5). Thus, alternative access to $2 H$-ent-ineleganolide (8) was sought employing the method used successfully applied to the oxidized analogs, beginning 
from ent-isoineleganolide A (13, Scheme 6A). ${ }^{11,12}$ Nucleophilic opening of epoxide $\mathbf{1 3}$ was accomplished in the presence of stoichiometric magnesium(II) bromide in a mixed solvent system at $70{ }^{\circ} \mathrm{C}$, providing bromide $\mathbf{1 4}$ in quantitative yield after concomitant transannular oxa-Michael addition. Subsequent installation of a ketone at $\mathrm{C}(6)$ was achieved under optimized Kornblum oxidation conditions to furnish ketopyran 9 in $96 \%$ yield. ${ }^{13}$ The efficiency of this transformation was ascribed to the ability of the transannular ethereal oxygen to stabilize the intermediate carbocation. ${ }^{10,11}$

Scheme 5. Unsuccessful Epoxide Rearrangement of Epoxide 11

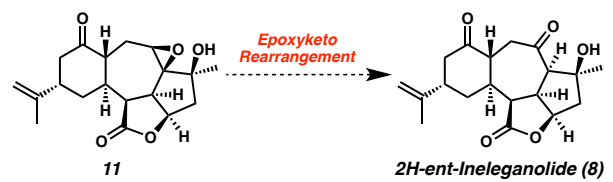

Scheme 6. Kornblum Oxidation for Formation of 1,4Diketone Moiety

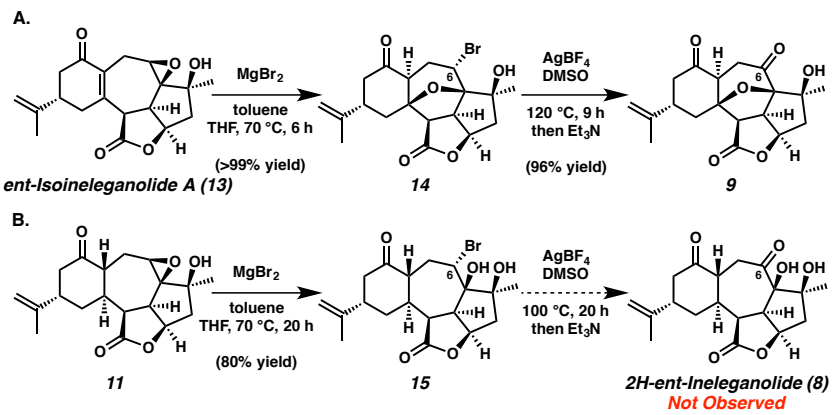

Application of this synthetic sequence to the reduced system began from epoxide 11, which was first opened with magnesium(II) bromide to provide bromohydrin 15 in $80 \%$ yield after an extended reaction time (Scheme 6B). Unfortunately, Kornblum oxidation conditions failed to install the desired ketone at $\mathrm{C}(6)$. The only products observed from the attempted oxidation of bromide 15 were dehydration products after prolonged exposure to elevated temperature under the reaction conditions. This result reinforces the hypothesis that the transannular ether in secondary bromide $\mathbf{1 4}$ is critical for the efficacy of the Kornblum oxidation.

In place of a Kornblum oxidation strategy to access $2 \mathrm{H}$ ent-ineleganolide (8), we began to pursue a reductive epoxide opening strategy employing $\mathrm{Cp}_{2} \mathrm{TiCl}$, which is generated in situ from $\mathrm{CpTiCl}_{2}$ and a suitable reductant. ${ }^{14}$ Initial exploration of this reductive epoxide opening proved immediately successful (Scheme 7). The use of $\mathrm{H}_{2} \mathrm{O}$ as an additive results in the formation of the $\mathrm{Cp}_{2} \mathrm{TiCl}$ aquo complex and thereby provides a sacrificial hydrogen atom donor. ${ }^{14 a, 15}$ Subsequent oxidation under optimized conditions using Dess-Martin periodinane (DMP) in 1,2-dichloroethane at elevated temperature provided $2 \mathrm{H}$-ent-ineleganolide (8) in 33\% yield over two steps with the translactonized ketone $\mathbf{1 6}$ isolated in identical yield. The structures of both $2 H$-ent-ineleganolide $(\mathbf{8})$ and lactone $\mathbf{1 6}$ were unambiguously determined by single crystal X-ray diffraction, confirming the desired relative configuration at $\mathrm{C}(7)$.
Scheme 7. Sequential Reductive Epoxide Opening and Carbinol Oxidation

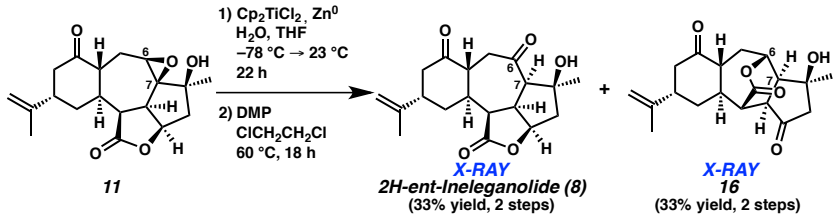

In order to explore the conformational constraints of $2 \mathrm{H}$ ent-ineleganolide (8), knowing the propensity of tetracyclic intermediates to adopt conformations distinct from that of ineleganolide, ${ }^{6 j, 11 a}$ we explored the in vacuo ground state energies (DFT/B3LYP/6-311+G**) of four different conformational isomers: $\mathbf{8}^{\mathbf{a x}}$ and $\mathbf{8}^{\text {equ }}$ and $\mathbf{8} \mathbf{A}^{\text {ax }}$ and $\mathbf{8} \mathbf{A}^{\text {equ }}$ (Figure 2). ${ }^{16}$ The two conformations in which the cyclohexanone ring adopts a chair conformation, placing the isopropenyl substituent in the axial position $\left(\mathbf{8}^{\mathbf{a x}}\right.$ and $\left.\mathbf{8} \mathbf{A}^{\mathbf{a x}}\right)$ are calculated to be energetically equivalent in the ground state, within the error of the calculation method $( \pm 0.23 \mathrm{kcal} / \mathrm{mol})$, and have the lowest ground state energies of the calculated isomers, mirroring the preferred conformation of ent-ineleganolide $\left(\right.$ ent $\left.^{\mathbf{a x}}{ }^{\text {ax }}\right)$ as determined on initial isolation by single crystal X-ray diffraction. ${ }^{6 j}$ The difference in energy between $\mathbf{8}^{\mathbf{a x}}$ and $\mathbf{8 A}^{\mathbf{a x}}$ and the corresponding equatorial conformations, $\mathbf{8}^{\text {equ }}$ and $\mathbf{8 A}^{\text {equ }}$, respectively, was calculated to be no more than $1.0 \mathrm{kcal} / \mathrm{mol}$. Complimentarily, the X-ray crystal structure of the isolated $2 H$-ent-ineleganlolide shows $\mathbf{8}^{\mathbf{a x}}$ is the preferred conformation. We were optimistic, however, that given the small ground state energy differences among these conformational isomers, we could induce an equilibrium between the isolated $\mathbf{8}^{\mathbf{a x}}$ and one of the conformational isomers $\mathbf{8} \mathbf{A}^{\mathbf{a x}}$ or $\mathbf{8} \mathbf{A}^{\text {equ }}$ en route the completion of the asymmetric total synthesis of entineleganolide (ent-1).
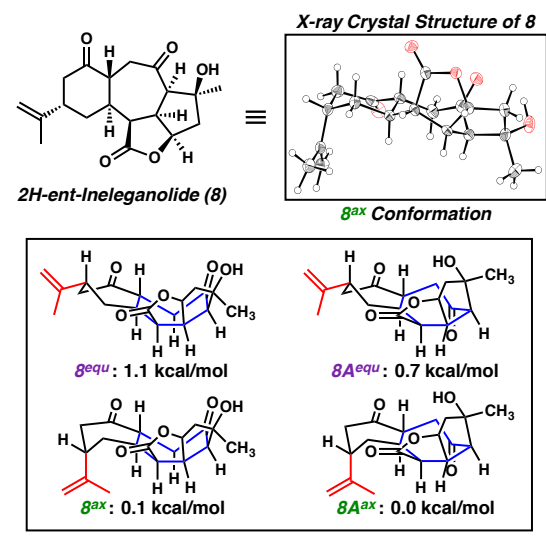

Figure 2. Computational Evaluation of Conformational Isomers of $2 \mathrm{H}$-ent-Ineleganolide (8).

Toward this end, completion of the total synthesis would require the oxidation of $2 \mathrm{H}$-ent-ineleganolide $(\mathbf{8})$ in order to install the final requisite $\mathrm{C}-\mathrm{O}$ bond and construct the characteristic bridging dihydrofuranone found within entineleganolide (ent-1). We envisioned accomplishing this transformation directly by $\mathrm{C}-\mathrm{H}$ functionalization at $\mathrm{C}(5)$ (Scheme 8). We focused on the application of $\mathrm{C}-\mathrm{H}$ functionalization methods that were known to accomplish the direct intramolecular formation a $\mathrm{C}-\mathrm{O}$ bond from a free hydroxyl group. We tested methods based on the Suárez oxidation including the standard reaction conditions $\left(\mathrm{PhI}(\mathrm{OAc})_{2}, \mathrm{I}_{2}, \mathrm{~h} v\right)$ and a series of modified Suarez oxidation conditions, which 
used mixed cyclohexane and dichloromethane solvent systems and exclude light. ${ }^{17}$ Additionally, we attempted the oxidation of C(5) using lead(IV) acetate and light ${ }^{18}$ as well as with functionalized hypervalent iodine reagents such as $\mathrm{PhI}(\mathrm{OH})(\mathrm{OTs}) .{ }^{19}$ Unfortunately, all reaction conditions explored failed to provide any product that was successfully oxidized at $\mathrm{C}(5)$.

Scheme 8. Attempted C(5) Oxidation by C-H Functionalization

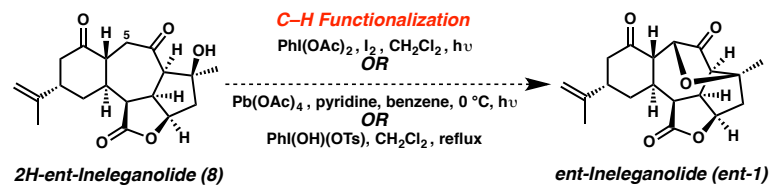

We also explored the potential to access ent-ineleganolide (ent-1) through the oxidation of $2 \mathrm{H}$-ent-ineleganolide (8), proceeding through vinylogous diketone 7 , which we hypothesized would undergo a spontaneous intramolecular oxaMichael addition to furnish ent-ineleganolide (ent-1, Scheme 9). Oxidative desaturation could be accomplished through either selective kinetic deprotonation relative to the cycloheptanone carbonyl at C(5) or by "thermodynamic" enolization relative to the cycloheptanone carbonyl at $\mathrm{C}(4)$. Complicated by potential enolization at $\mathrm{C}(2)$ and $\mathrm{C}(7)$, all attempts to accomplish this transformation by direct oxidation using palladium(II) salts (e.g., $\left.\mathrm{Pd}(\mathrm{OAc})_{2}, \mathrm{Pd}(\mathrm{TFA})_{2}\right),{ }^{20}$ hypervalent iodine reagents (e.g., IBX), ${ }^{21}$ or various selenides (e.g., $(\mathrm{PhSeO})_{2} \mathrm{O}$, $\mathrm{PhSeCl}$ then $\mathrm{H}_{2} \mathrm{O}_{2}$ ) failed to yield any trace of intermediate 7 or ent-ineleganolide (ent-1), typically resulting in selective functionalization at $\mathrm{C}(2) .{ }^{22}$ Similar nonproductive reactivity was observed when attempting the $C(4)-C(5)$ oxidation by a Saegusa-Ito oxidation. ${ }^{23}$ In order to avoid the undesired functionalization of the cyclohexanone ring, the selective reduction of the $\mathrm{C}(3)$ carbonyl was explored. While the selective reduction of the $\mathrm{C}(3)$ ketone in the presence of the $\mathrm{C}(6)$ carbonyl of $2 \mathrm{H}$-ent-ineleganolide (8) could not be achieved, we sought to reduce the $\mathrm{C}(3)$ ketone at an earlier stage.

Scheme 9. Representative Reaction Conditions for Attempted C(4)-C(5) Oxidative Desaturation

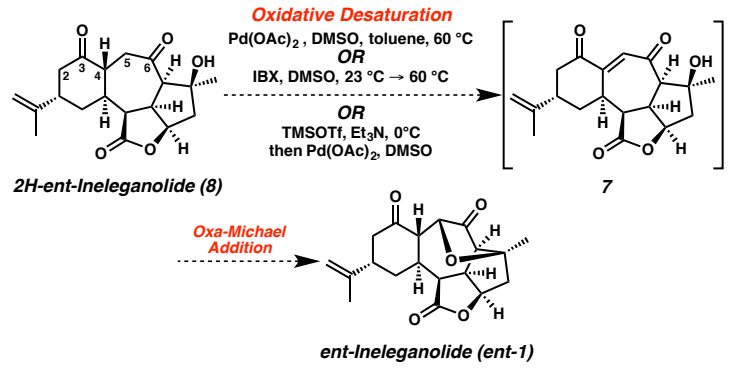

Stereoselective reduction of ketone $\mathbf{1 2}$ at C(3) was accomplished using L-selectride at low temperature (Scheme 10). ${ }^{24}$ Subsequent silylation of the intermediate secondary alcohol provided tetracycle $\mathbf{1 7}$ in $\mathbf{7 9} \%$ yield over two steps. Epoxidation could then be smoothly accomplished to furnish epoxyalcohol 18 in $80 \%$ yield. Reductive epoxide opening of pentacycle 18 under optimized conditions using in situ generated titanium(III) resulted in concomitant translactonization, affording alcohol 19 in $66 \%$ yield as the sole product. Unable to manipulate lactone $\mathbf{1 9}$ further toward ineleganolide we again revised our retrosynthetic strategy.
Scheme 10. Advancement of Tetracycle 12 by Diastereoselective C(3) Reduction
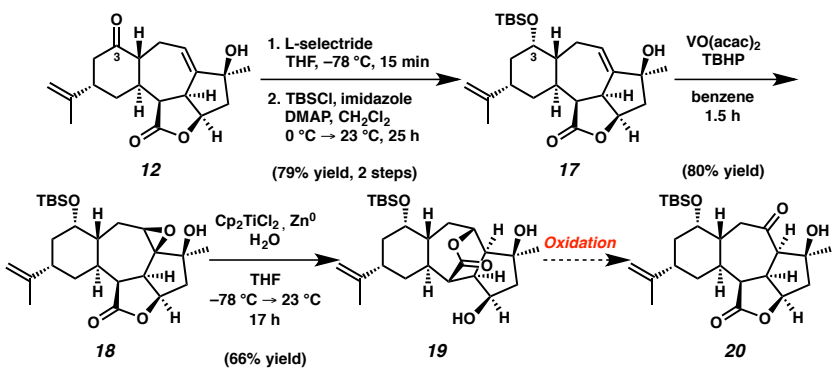

Armed with knowledge that selective late-stage functionalization of the tetracyclic core is complicated by the presence of the ketone functionality at $\mathrm{C}(3)$, access to ent-ineleganolide (ent-1) was envisioned after oxidation of secondary alcohol 21 and ultimate intramolecular oxa-Michael addition (Scheme 11). Access to enone 21 was anticipated by the isomerization of olefin 22 into conjugation with the isolated ketone at $\mathrm{C}(6)$ followed by deprotection of the masked secondary $\mathrm{C}(3)$ hydroxyl group. Ketone $\mathbf{2 2}$ would be synthesized after the stereoselective epoxide rearrangement or sequential reductive epoxide opening-oxidation from epoxide 23, which would be accessible from ent-isoineleganolide A (13) after selective 1,2reduction of the conjugated system and subsequent protection.

Scheme 11. Retrosynthetic Analysis of ent-Ineleganolide (ent-1) Employing a Reduction at C(3)

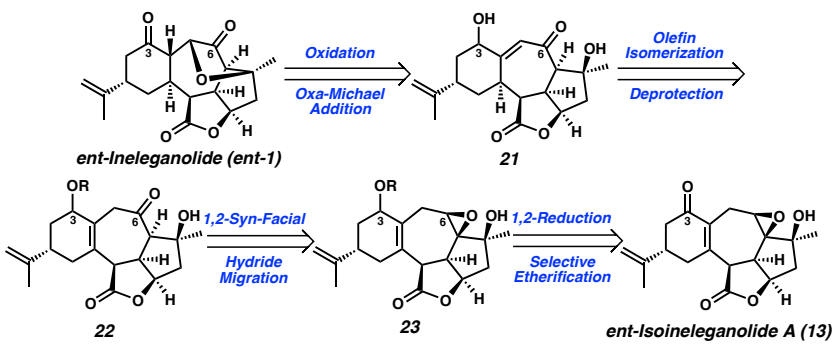

Exploration of the revised synthetic route began with the development of conditions that could accomplish the chemoselective 1,2-reduction of cyclohexenone 13 (Scheme 12). Gratifyingly, this transformation could be accomplished chemoselectively and diastereoselectively using sodium borohydride in a mixed $\mathrm{CH}_{2} \mathrm{Cl}_{2}$ and $\mathrm{MeOH}$ solvent system at low temperature to provide allylic alcohol $\mathbf{2 4}$ in quantitative yield as a single diastereomer. ${ }^{25}$ With alcohol 24 in hand, the potential to accomplish an epoxide rearrangement on this reduced system was evaluated. To thoroughly evaluate this desired reactivity, selective protection of the hydroxyl groups on substrate $\mathbf{2 4}$ was accomplished, allowing for the isolation of monoprotected allylic alcohol 25 and bis-silyl ether 26. Unfortunately, as with all other epoxides containing the [6,7,5,5]-core related to ent-ineleganolide (ent-1), diol 27, allylic alcohol 28, and bis-silyl ether 29 all failed to undergo the desired 1,2hydride shift (Scheme 13). 
Scheme 12. Chemoselective Reduction of entIsoineleganolide A (13)
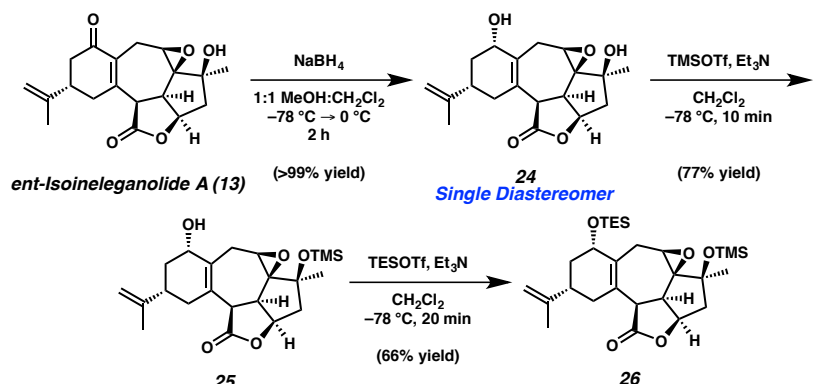

Scheme 13. Attempted Epoxide Rearrangement

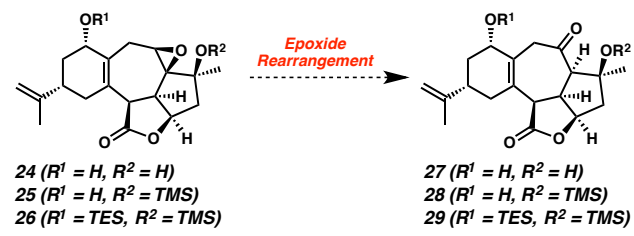

During this investigation, we sought to assess the reactivity of an analog of diol $\mathbf{2 4}$ that was functionalized with a silyl ether at solely the allylic secondary alcohol. Under standard imidazole-mediated silylation conditions employing a bulky silyl chloride, synthesis of silyl ether $\mathbf{3 0}$ was achieved in $26 \%$ yield (Scheme 14). Surprisingly allylic silyl ether $\mathbf{3 0}$ was the minor product. The remaining portion of diol $\mathbf{2 4}$ had been converted to $\alpha, \beta$-unsaturated lactone $\mathbf{3 1}$ as the major product. Under optimized conditions, conjugated lactone 31 was produced in $74 \%$ yield. $^{26}$

Scheme 14. Silyl Ether Formation with Unexpected Olefin Isomerization

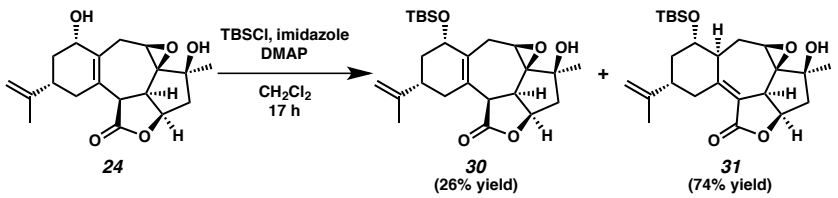

Intrigued by $\alpha, \beta$-unsaturated lactone 31, the configurational stability of the isomerized olefin was explored. Deprotection of silyl ether $\mathbf{3 1}$ using TBAF provided secondary alcohol 32 in quantitative yield (Scheme 15). Unfortunately, oxidation of secondary alcohol 32 with DMP was accompanied by concomitant olefin migration back into conjugation at the $[6,7]$ ring fusion providing ent-isoineleganolide A (13) in 66\% yield. No trace of the desired $\alpha, \beta$-unsaturated lactone (33) was detected. Although this oxidative route proved unfruitful, simply returning the original enone starting material (13) after 4 synthetic transformations, the investigation of the utility of silyl ether isomers $\mathbf{3 0}$ and $\mathbf{3 1}$ in synthetic efforts toward entineleganolide (ent-1) continued.
Scheme 15. Assessment of Configurational Stability of Unsaturated Lactone Moiety

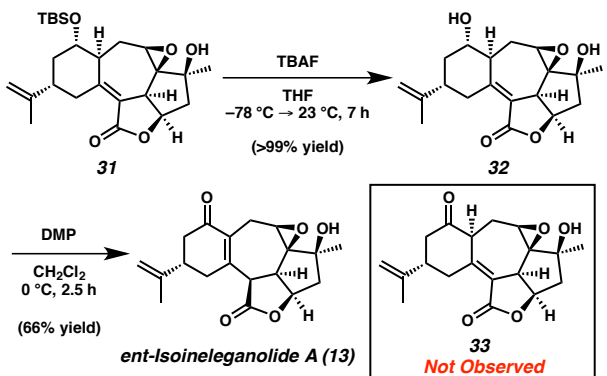

In order to advance toward ent-ineleganolide (ent-1), the epoxide moiety within diol $\mathbf{2 4}$, allylic ether $\mathbf{3 0}$, or unsaturated lactone 31 would need to be converted into the requisite $C(6)$ ketone. Unfortunately diol 24, the precursor to silyl ether isomers 30 and 31, proved to be an unsuitable substrate for titanium(III)-mediated reductive epoxide opening (Scheme 16). ${ }^{27}$ Contrastingly, silyl ethers $\mathbf{3 0}$ and $\mathbf{3 1}$ proved to be competent substrates for this transformation (Schemes 17). ${ }^{28}$ Epoxide opening of allylic silyl ether $\mathbf{3 0}$ provided translactonized alcohol $\mathbf{3 6}$ as the sole product in $60 \%$ yield (Scheme 17A). Subsequent oxidation failed to induce the desired retrotranslactontization, furnishing ketone $\mathbf{3 7}$ as the only isolable product without any trace of desired cycloheptanone 38. Transannular lactone $\mathbf{3 7}$ was not immediately useful for continued advancement toward ent-ineleganolide (ent-1).

Scheme 16. Attempted Reductive Opening of Epoxide 24

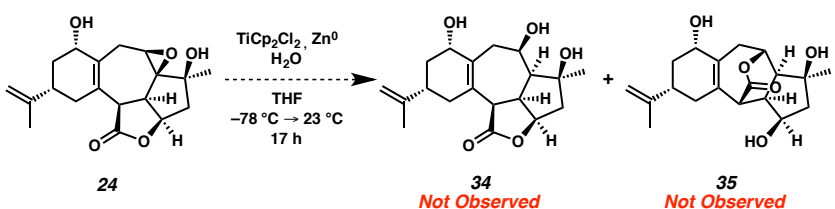

Scheme 17. Reductive Epoxide Opening of Isomeric Silyl Ethers 30 and 31
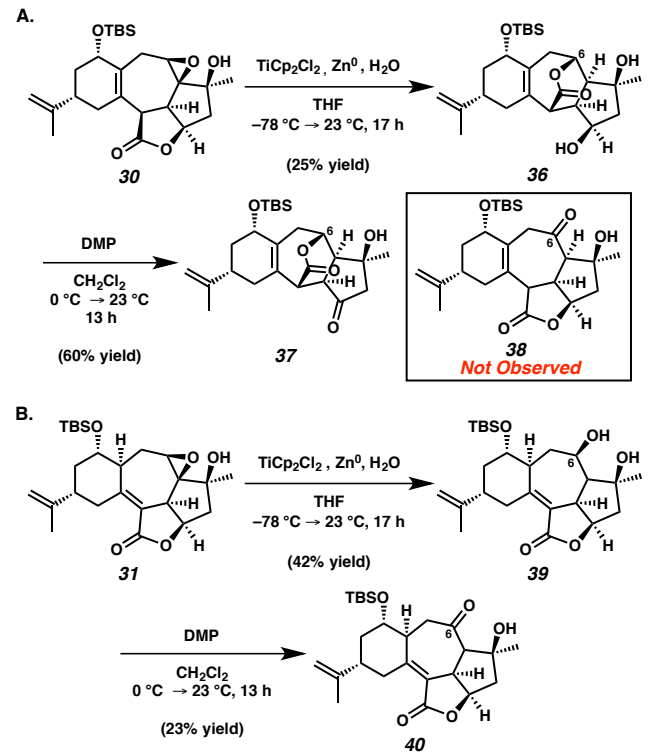

Alternatively, exposure of $\alpha, \beta$-unsaturated lactone 31 to identical titanium(III)-mediated reductive conditions accomplished the desired epoxide opening while avoiding any translactonization, affording 1,3-diol 39 in $42 \%$ yield (Scheme 
17B). ${ }^{28}$ Interestingly, under these reducing and Lewis acidic conditions, the reduction of the $\alpha, \beta$-unsaturated lactone moiety was not detected. Advancing diol 39 by oxidation of the secondary alcohol with DMP smoothly provided ketone $\mathbf{4 0}$ in $23 \%$ yield as the sole product.

With ketone 40 in hand, we sought to accomplish the installation of the unsaturation required between $\mathrm{C}(4)$ and $\mathrm{C}(5)$ for the vinylogous diketone system and ultimate oxa-Michael addition to build the desired dihydrofuranone. Using triethylsilyl triflate (TESOTf) and $\mathrm{Et}_{3} \mathrm{~N}$, desired enol ether 41 could be constructed, albeit with undesired concomitant hydration of the $\alpha, \beta$-unsaturated lactone (Scheme 18). Unfortunately, we were unable to advance further toward entineleganolide (ent-1) at this stage as the oxidation of this enol ether 41 could not be accomplished. ${ }^{29}$

Scheme 18. Silyl Enol Ether Formation from Ketone 40

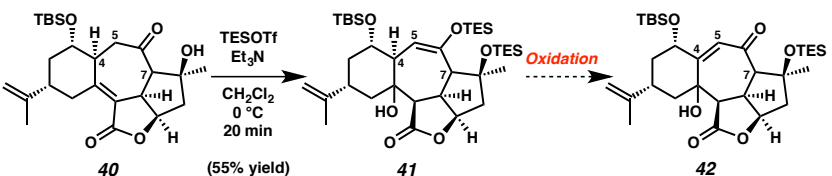

To test if the steric bulk of silyl enol ether $\mathbf{4 1}$ was preventing oxidation, silylation of tetracycle $\mathbf{4 0}$ was explored in a stepwise fashion. Tertiary alcohol $\mathbf{4 0}$ was first protected as trimethylsilyl (TMS) ether 43 (Scheme 19). Surprisingly, when ketone $\mathbf{4 3}$ was subjected to silyl enol ether formation conditions, although the starting material was fully consumed, no trace of either desired enol ether $\mathbf{4 4}$ or its hydrated analog were detected in the product mixture. ${ }^{22}$

\section{Scheme 19. Attempted Formation of TMS Enol Ether 44}

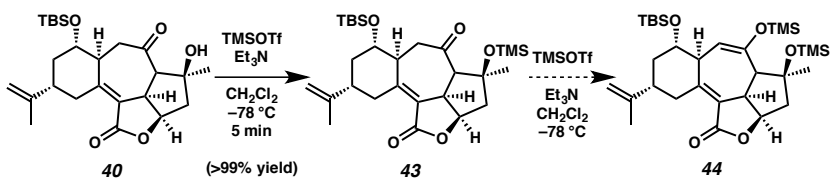

Unfortunately, alternative advancement of ketone $\mathbf{4 0}$ or its diol precursor (39) by selective conjugate reduction of the unsaturated lactone could not be accomplished. Although the $\alpha, \beta$-unsaturated lactone moiety within these compounds had enabled the installation of the C(6) ketone (i.e., 39), the inability to advance further toward ent-ineleganolide (ent-1) forced another reevaluation of the synthetic strategy.

As such, development of an alternative pathway to avoid the problematic translactonization regularly observed using the titanium(III)-mediated epoxide openings began (cf. Schemes 7, 10, and 17). To prevent this undesired isomerization, the potential to mask the lactone as a lactol by reducing earlier synthetic intermediates was investigated. Beginning with either diene tetracycle 5 (Scheme 20A) or epoxide 13 (Scheme 20B), a completely diastereoselective double reduction could be accomplished in the presence of excess diisobutylaluminum hydride (DIBAL) at low temperature to afford either allylic alcohol 45 or epoxyalcohol 46, respectively. The relative stereochemistry of reduction products 45 and 46 was not rigorously assigned. Although the selective reduction of the lactol was desired, reduction of the isolated ketone was the requisite precursor, as evidenced by the isolation of allylic alcohol 47 as the sole two-electron reduction product detectable (Scheme 20C). Since a late-stage oxidation would be required in this route to regenerate the lactone moiety, the advancement of the observed reduced lactols $\mathbf{4 5}$ and $\mathbf{4 6}$ could still be employed to advance toward ent-ineleganolide (ent-1) in short sequence.
Scheme 20. Lactol Formation
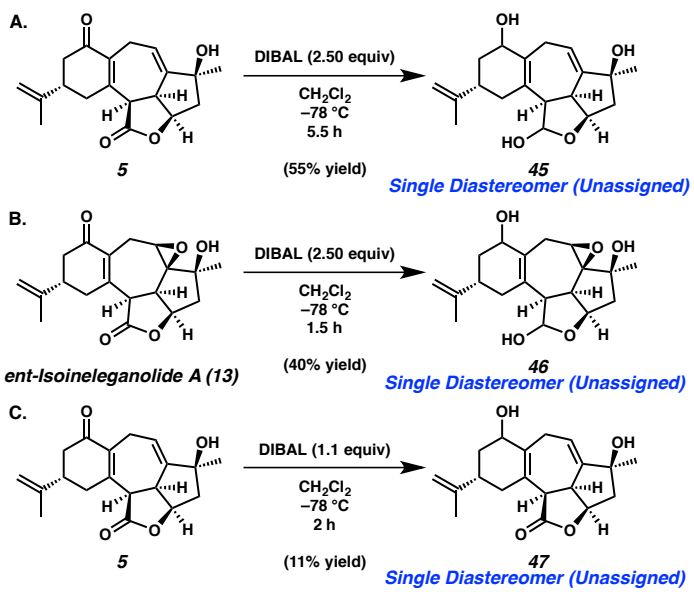

Exploiting the higher yielding reduction of diene 5 compared to epoxide 13, we chose to advance employing lactol 45. Bis-silylation of secondary alcohol $\mathbf{4 5}$ using tertbutyldimethylsilyl chloride (TBSCl) under standard conditions provided lactol ether 48 in $89 \%$ yield (Scheme 21). Epoxidation of allyl alcohol $\mathbf{4 8}$ was then efficiently accomplished in $90 \%$ yield to furnish epoxide 49 . Titanium(III)-mediated epoxide opening accomplished the regioselective epoxide opening, smoothly furnishing a single product. The product observed had undergone an intramolecular transketalization, furnishing acetal $\mathbf{5 0}$ in $89 \%$ yield. ${ }^{28}$ Yet again, an intermediate was produced that was not useful for the progression toward ent-ineleganolide (ent-1) as opening of the acetal under acidic or oxidative conditions could not be achieved. Oxidative reactions using $\mathrm{SO}_{3} \bullet$ pyridine in DMSO, DMP in wet $\mathrm{CH}_{2} \mathrm{Cl}_{2}$, other hypervalent iodine oxidants in wet solvents, and chromium oxidants all proved ineffective, routinely quantitatively returning the starting material after reaction times up to 7 days at elevated temperatures.

Scheme 21. Advancement of Lactol 45

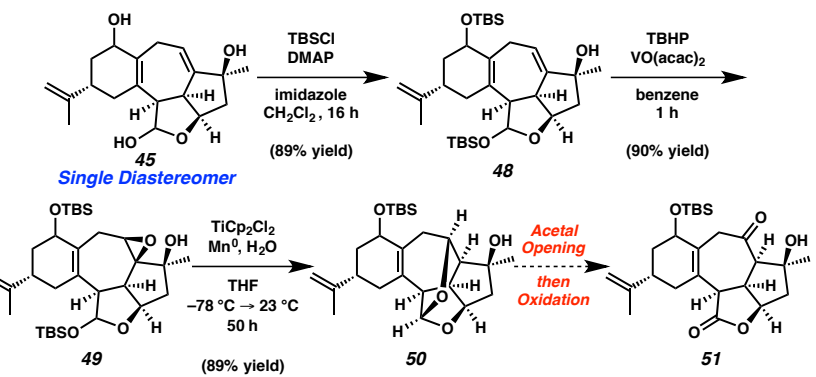

Unable to advance acetal $\mathbf{5 0}$ further, we had again encountered an unsuccessful synthetic strategy pairing early-stage reduction with late-stage oxidation. Thus, we turned to the antipodal retrosynthetic strategy employing an early-stage oxidation, requiring a late-stage reduction to complete entineleganolide (ent-1, cf. Scheme 2B).

Alternative completion of the asymmetric total synthesis of ent-ineleganolide (ent-1) was envisioned after dehydration of ketofuran $\mathbf{5 2}$ paired with ultimate conjugate reduction (Scheme 22). Synthesis of dihydrofuranone $\mathbf{5 2}$ would be accomplished by an intramolecular oxa-Michael addition from vinylogous diketone 53. Access to enedione 53 was envisioned through the selective reductive opening of dihydropy- 
ranone 54. Access to dihydropyranone 54 would be achieved after the oxidation of saturated 1,4-diketone 9.

Scheme 22. Retrosynthetic Analysis of ent-Ineleganolide (ent-1) Employing Late-Stage Reduction

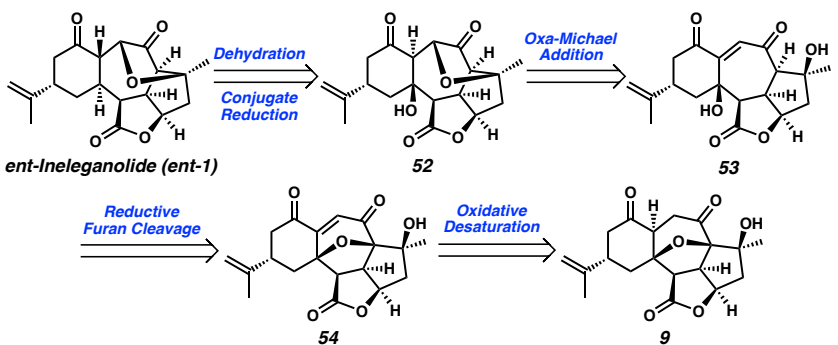

Evaluation of this synthetic route began with the previously synthesized intermediate ketopyran 9 (Scheme 23). ${ }^{10,11}$ Formation of the thermodynamic TMS enol ether at C(3) enabled the subsequent Saegusa-Ito oxidation, smoothly furnishing vinylogous diketone $\mathbf{5 5}$ in $56 \%$ yield as the major product. Unfortunately, even under optimized conditions, the production of polyunsaturated diketone $\mathbf{5 6}$ could not be avoided, which was isolated in $44 \%$ yield. ${ }^{30}$

\section{Scheme 23. Oxidation of 1,4-Diketone 9}

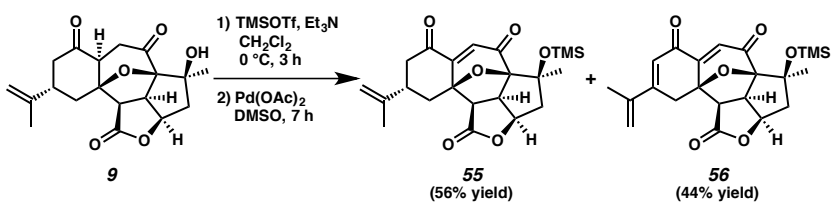

With vinylogous diketone $\mathbf{5 5}$ in hand, the investigating reductive $\alpha$-alkoxyketone cleavage procedures commenced. These studies focused on the use of $\mathrm{SmI}_{2}$ considering that this reagent is known to accomplish related transformations ${ }^{31}$ and has been used previously for the $\alpha$-alkoxyketone cleavage of saturated 1,4-diketone 9. ${ }^{10,11}$ The use of $\mathrm{SmI}_{2}$ in the absence of an additive or with $\mathrm{H}_{2} \mathrm{O}, \mathrm{LiCl}, \mathrm{LiBr}, \mathrm{HMPA}$, or $t$-BuOH all failed to provide any trace of enedione 53 (Scheme 24). Rather, all conditions selectively reduced the conjugated system. For example, exposure of enedione $\mathbf{5 5}$ to $\mathrm{SmI}_{2}$ at low temperature followed sequentially by TBAF-mediated tertiary silyl ether cleavage produced saturated diketone 9 in $75 \%$ yield.

Scheme 24. Reduction of Vinylogous Diketone 55

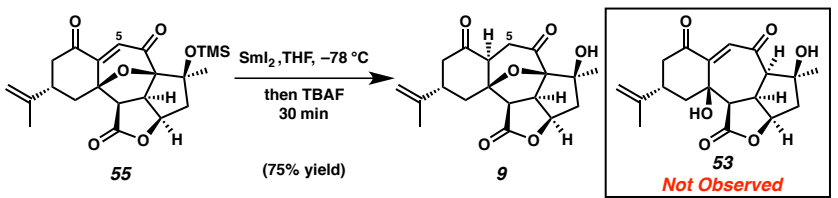

Unable to advance further toward ent-ineleganolide (ent-1) using dihydropyranone $\mathbf{5 5}$, but inspired by access to dihydropyranone 55 as the first intermediate with oxidation of $\mathrm{C}(5)$, we regressed further in the synthetic route to find other substrates that could be oxidized in a productive fashion. We were pleased to find that ent-isoineleganolide A (13) could be selectively enolized at the $\gamma$-position of the conjugated system when DMAP was used as the base (Scheme 25). Formation of both dienol ether 57 (Scheme 25A) and dienol acetate 58 (Scheme 25B) could be achieved using TESCl and acetic anhydride, respectively. Although TES dienol ether 57 could be isolated and purified on small scale, attempts to increase the scale of its production routinely resulted in hydrolysis during purification and reformation of starting material 13. Although the formation of the analogous triisopropylsilyl (TIPS) dienol ether could not be accomplished under similar conditions, the TBS analog could be formed using TBSCl in place of TESCl, furnishing a significantly more stable product that was used for further synthetic studies.

\section{Scheme 25. Dienol Ether Formation}

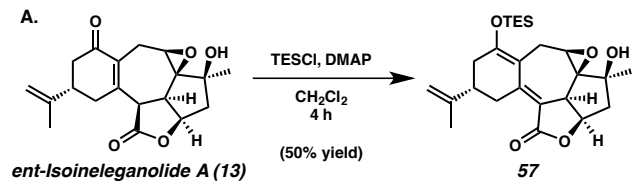

B.

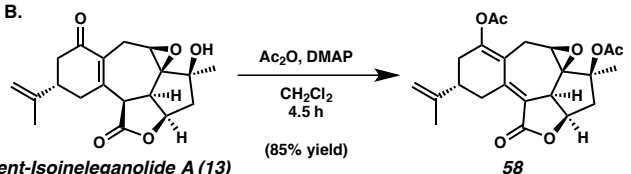

In order to advance the dienol ether substrates toward entineleganolide (ent-1), exploration of the employment of the previously utilized titanium(III)-mediated reductive epoxide opening conditions was explored. ent-Isoineleganolide A (13) was first converted into the TBS dienol ether $\mathbf{5 9}$ and was subsequently exposed to titanium(III)-mediated reductive conditions (Scheme 26). Not only did hydrolysis of dienol ether 59 occur under the reaction conditions, but solely the recovery of starting material $\mathbf{1 3}$ was observed without the detection of desired product 60 or hydrolysis product 61 .

\section{Scheme 26. Attempted Reductive Epoxide Opening of} Dienol Ether 59

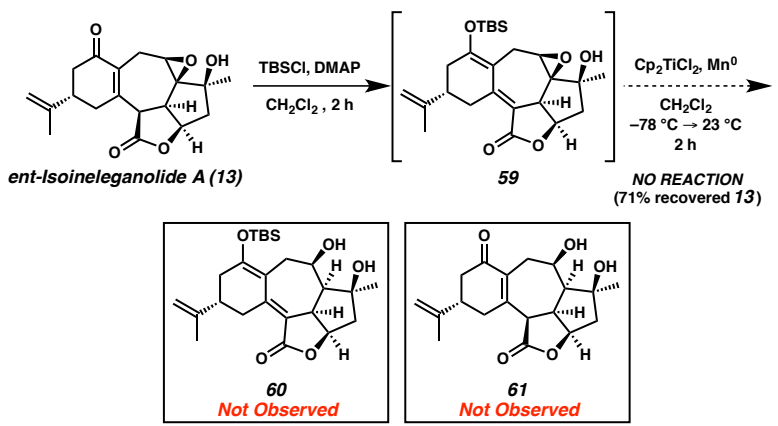

Comparably, dienol acetate $\mathbf{5 8}$ proved an incompetent substrate for reductive epoxide opening under the same conditions (Scheme 27). Rather than producing desired product 62, quantitative return of the staring material (58) was observed.

Scheme 27. Attempted Reductive Epoxide Opening of Dienol Ether 58

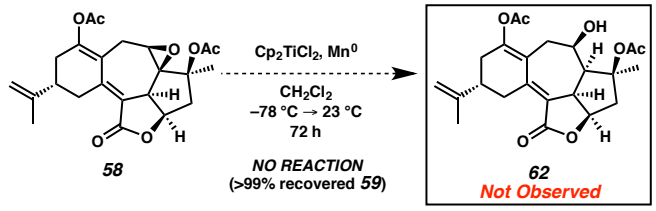

Leaving the epoxide opening for a later stage, the oxidative advancement of these dienol ether intermediates (57 and 58) was explored. In an attempt to functionalize entisoineleganolide A (13) at C(4), we first formed the TBS dienol ether (Scheme 28). Exposure of this intermediate to NBS in dichloromethane at room temperature afforded solely $\alpha$-bromolactone 63 rather than $\alpha$-bromoketone $64 .^{32}$ We did not believe $\gamma$-bromide $\mathbf{6 3}$ was useful for progression toward 
ent-ineleganolide (ent-1), thus alternative oxidative procedures were explored.

\section{Scheme 28. Construction of $\alpha$-Bromolactone 63}

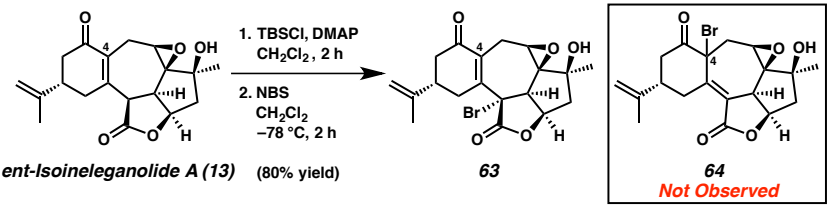

During that investigation, we were gratified to find $\mathrm{C}(4)$ $\mathrm{C}(5)$ oxidation of ent-isoineleganolide A (13) could indeed be accomplished (Scheme 29). Beginning again with the formation of the TBS dienol ether from epoxide 13, oxidation using stoichiometric palladium(II) acetate in DMSO provided ent-dehydroisoineleganolide (65) in $60 \%$ yield. Unfortunately, this transformation was plagued by routinely low yields on increased scale, but afforded enough material to continue synthetic explorations.

Scheme 29. Oxidation of ent-Isoineleganolide A (13) to Cycloheptadiene 65

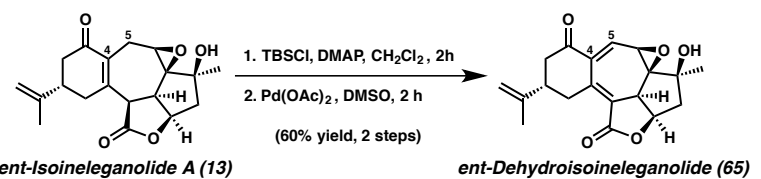

ent-Dehydroisoineleganolide (65) was characterized by unique spectroscopic features, including an unexpected ${ }^{13} \mathrm{C}$ NMR spectrum. For example, consider ent-isoineleganolide A (13) and the ${ }^{13} \mathrm{C}$ NMR shifts of C6 and $\mathrm{C} 7$ at $54.5 \mathrm{ppm}$ and 70.2 ppm, respectively (Figure 3 ). These shifts were characteristic with the remaining epoxytetracycles synthesized throughout this study (e.g., 11, 18, 24-26, 30-31, 57-58, 63). In contrast, while the carbon shift of the secondary epoxide carbon C6 of ent-dehydroisoineleganolide (65) is within the expected range at $52.1 \mathrm{ppm}$, the tertiary epoxide carbon $\mathrm{C} 7$ is found at $94.9 \mathrm{ppm}$. We hoped that the spectral data associated with ent-dehydroisoineleganolide (65) was indicative of a reactivity profile that could be exploited.

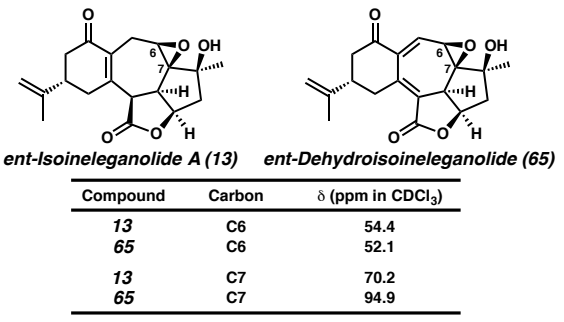

Figure 3. Comparison of ${ }^{13} \mathrm{C}$ NMR Shifts of Enone 13 and Diene 65.

Any further advancement toward ent-ineleganolide (ent-1) would now require the opening of the epoxide moiety. Unfortunately, ent-dehydroisoineleganolide (65) was extremely reactive under titanium(III)-mediated reductive epoxide opening conditions, largely decomposing upon initiation of the reaction and routinely furnishing a complex mixture of products. Additionally, all attempts to accomplish a Lewis acid-mediated 1,2-hyride shift and generation of the vinylogous diketone (67) were unfruitful. In fact, the only productive reactivity observed during this screen was the production of cyclohepta- trienone 66 from ent-dehydroisoineleganolide (65) in 75\% yield in the presence of $\mathrm{Yb}(\mathrm{OTf})_{3}$ (Scheme 30).

Scheme 30. Formation of ent-Didehydroisoineleganolide (66)

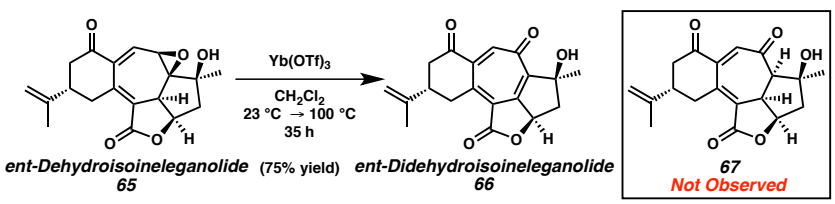

\section{CONCLUSIONS}

We have disclosed a research program dedicated to developing synthetic access to the core structures of the polycyclic furanobutenolide-derived norcembranoid diterpene natural products. Enantioselective construction of the tetracyclic core of ineleganolide (1) employed a palladium-catalyzed asymmetric allylic alkylation for the formation of a fully substituted chiral tertiary ether center (blue, Scheme 31 ). This stereocenter was then used to relay chiral information to all remaining stereocenters within the [7,5,5]-tricyclic portion of the ineleganolide core (red) through a diastereoselective reduction followed by a key cyclopropanation-Cope rearrangement cascade. $^{10,11,33}$

Scheme 31. Asymmetric Allylic Alkylation Stereoselectively Determines All Remaining Chiral Information

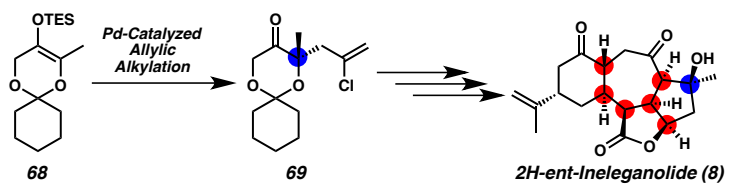

Although the synthesis of neither ineleganolide (1) nor any member of the polycyclic furanobutenolide-derived norcembranoid diterpene natural product family has yet been accomplished, this synthetic program has facilitated the construction of the core of any member for the first time and the first synthetic isomers and analogs of ineleganolide (1). These natural product-like ineleganoloids advanced the understanding of the conformational restraints influencing chemistry of the highly compact norcembranoid diterpene scaffold and have led to the identification of biologically active ineleganolide analogs (Figure 4). ${ }^{10,11}$ Currently, the biological activity this class of synthetic, natural product-like compounds is in the process of being evaluated in collaboration with Eli Lilly ${ }^{34}$ and the City of Hope. ${ }^{35}$

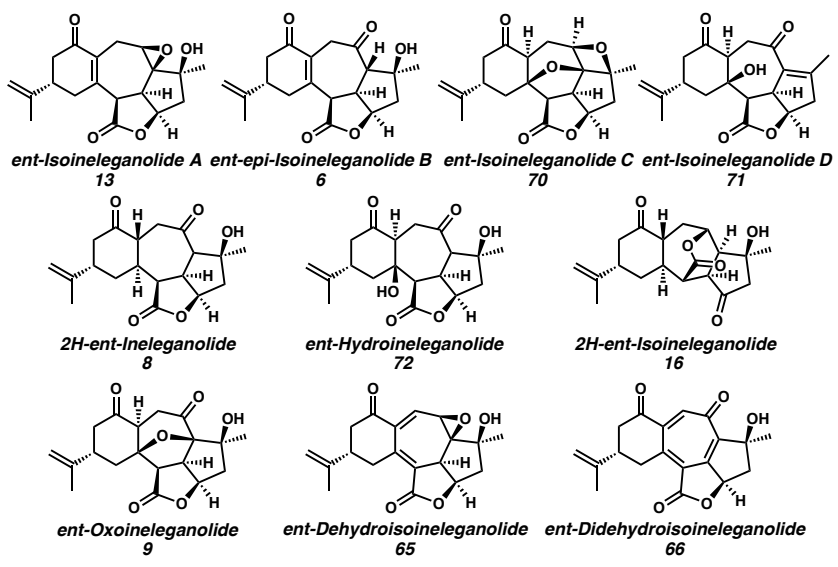


Figure 4. The Synthetic Natural Product-Like Ineleganoloids.

Throughout the course of this research program, we have thoroughly explored the limits of chemical transformation on complex, constrained fused cycloheptane polycycles. The understanding of this chemistry will not only benefit continued efforts toward the completion of the first asymmetric total synthesis of ineleganolide (1), but also will be broadly applicable to other total synthetic and semi-synthetic efforts toward the polycyclic furanobutenolide-derived norcembranoids as well as other terpenoid and alkaloid natural products. Perhaps then, the greater value in total synthesis is truly derived from the journey taken rather than that simply found at the finish line.

\section{ASSOCIATED CONTENT}

\section{Experimental Section}

General Methods. Unless stated otherwise, reactions were performed at ambient temperature $\left(23^{\circ} \mathrm{C}\right)$ in flame-dried or oven-dried glassware under an argon or nitrogen atmosphere using dry, deoxygenated solvents (distilled or passed over a column of activated alumina), ${ }^{36}$ being stirred with a Teflon ${ }^{\circledR}$-coated magnetic stirring bar. Commercially available reagents were used as received unless otherwise noted. $\mathrm{Et}_{3} \mathrm{~N}$ was distilled from calcium hydride immediately prior to use. $\mathrm{MeOH}$ was distilled from magnesium methoxide immediately prior to use. Reagent grade acetone was obtained from Sigma-Aldrich and used as received. Purified water was obtained using a Barnstead NANOpure Infinity UV/UF system. Diene $5,{ }^{10}$ ent-Isoineleganolide A (13), ${ }^{10}$ ent-oxoineleganolide (9), ${ }^{10}$ were prepared by known methods. Reactions requiring external heat were modulated to the specified temperatures using an IKAmag temperature controller. Thin-layer chromatography (TLC) was performed using E. Merck silica gel $60 \mathrm{~F} 254$ precoated plates $(250 \mathrm{~nm})$ and visualized by UV fluorescence quenching, potassium permanganate, or $p$-anisaldehyde staining. Silicycle SiliaFlash P60 Academic Silica gel (particle size 40-63 nm) was used for flash chromatography. ${ }^{1} \mathrm{H}$ and ${ }^{13} \mathrm{C}$ NMR spectra were recorded on a Varian Inova 600 (600 MHz and $151 \mathrm{MHz}$, respectively), Varian Inova 500 (500 MHz and $126 \mathrm{MHz}$, respectively), Bruker AV III HD spectrometer equipped with a Prodigy liquid nitrogen temperature cryoprobe $(400 \mathrm{MHz}$ and $101 \mathrm{MHz}$, respectively), or a Varian Mercury 300 spectrometer ( $300 \mathrm{MHz}$ and $76 \mathrm{MHz}$, respectively) and are reported in terms of chemical shift relative to residual $\mathrm{CHCl}_{3}$ (in $\mathrm{CDCl}_{3}, \delta 7.26$ and $\delta 77.16$, respectively) or $\mathrm{C}_{6} \mathrm{D}_{5} \mathrm{H}$ (in $\mathrm{C}_{6} \mathrm{D}_{6}, \delta 7.16$ and $\delta 128.06$, respectively). Data for ${ }^{1} \mathrm{H}$ NMR spectra are reported as follows: chemical shift ( $\delta \mathrm{ppm})($ multiplicity, coupling constant (Hz), integration). Infrared (IR) spectra were recorded on a Perkin Elmer Paragon 1000 Spectrometer and are reported in frequency of absorption $\left(\mathrm{cm}^{-1}\right)$. High resolution mass spectra (HRMS) were acquired using an Agilent 6200 Series TOF mass spectrometer with an Agilent G1978A Multimode source in atmospheric pressure chemical ionization (APCI) or mixed (MultiMode: ESI-APCI) ionization mode or were obtained from the Caltech Mass Spectral Facility using either a JEOL JMS-600H High Resolution Mass Spectrometer in fast atom bombardment $(\mathrm{FAB}+)$ or electron ionization $(\mathrm{EI}+)$ mode or an LCT Premier XE TOF mass spectrometer equipped with an electrospray ionization source (ES+). Optical rotations were measured on a Jasco P-2000 polarimeter using a $100 \mathrm{~mm}$ path length cell at $589 \mathrm{~nm}$.

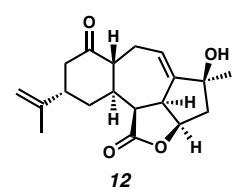

$\left(2 \mathrm{a} R, 2 \mathrm{a}^{1} S, 4 S, 6 \mathrm{a} R, 9 S, 10 \mathrm{a} S, 10 \mathrm{~b} S\right)-4-h y d r o x y-4-m e t h y l-9-$ (prop-1-en-2-yl)-2a ${ }^{1}, 3,4,6,6 a, 8,9,10,10 a, 10 b-d e c a h y d r o-1 H$ benzo[6,7]azuleno[1,8-bc]furan-1,7(2aH)-dione (12).

Preparation of a $0.07 \mathrm{M}$ Stock Solution $\mathrm{SmI}_{2}$

Into each of two Schlenk tubes was added freshly filed samarium metal ( $150 \mathrm{mg}, 1.00 \mathrm{mmol}, 6.25$ equiv). The reaction vessel was then thoroughly flame-dried, backfilled with argon, and allowed to cool to ambient temperature (ca. $23{ }^{\circ} \mathrm{C}$ ). To each reaction vessel was added THF $(10.0 \mathrm{~mL})$ that had previously been sparged with argon for 60 minutes and cooled to $0{ }^{\circ} \mathrm{C}$ (ice $/ \mathrm{H}_{2} \mathrm{O}$ bath) with stirring. Diiodoethane $(200 \mathrm{mg}, 0.71 \mathrm{mmol}, 4.44$ equiv) was then added to each Schlenk tube in separate $100 \mathrm{mg}$ portions 30 minutes apart. After the addition of the second portion, the Schlenk tubes were removed from the cooling bath, allowed to warm to ambient temperature (ca. $23{ }^{\circ} \mathrm{C}$ ), and the pale yellow solution was stirred overnight (ca. $14 \mathrm{~h}$ ) causing the reaction to become deep blue, indicating formation of $\mathrm{SmI}_{2}$.

Reduction of Diene 5

Each Schlenk tube was cooled to $-78{ }^{\circ} \mathrm{C}$ ( $i-\mathrm{PrOH} /$ dry ice bath $)$ followed by the addition of $\mathrm{H}_{2} \mathrm{O}(75 \mu \mathrm{L}, 4.16 \mathrm{mmol}, 26.0$ equiv). After stirring for 5 minutes, the addition of diene 5 (50 mg, 0.16 mmol, 1.00 equiv) as solution in thoroughly sparged THF (1.60 $\mathrm{mL}$ ) was accomplished quickly dropwise over 4 minutes. After 2 $\mathrm{h}$, the reaction vessel was warmed to $0{ }^{\circ} \mathrm{C}$ (ice $/ \mathrm{H}_{2} \mathrm{O}$ bath). After an additional $2 \mathrm{~h}$, the Schlenk tube was removed from the cooling bath and allowed to warm. After 20 minutes, before warming all the way to ambient temperature (ca. $23{ }^{\circ} \mathrm{C}$ ), the consumption of starting material was complete as determined by TLC (1:4 EtOAc: $\mathrm{CH}_{2} \mathrm{Cl}_{2}$ eluent). The dark blue reaction mixture was quenched by the addition of hexanes $(10.0 \mathrm{~mL})$ and $\mathrm{H}_{2} \mathrm{O}(0.10$ $\mathrm{mL})$. After stirring for 5 minutes, both reaction mixtures were combined, filtered through a pad of silica gel $(50 \%$ acetone in hexanes eluent), and concentrated in vacuo. The crude tan solid was purified by silica gel column chromatography $(20 \%$ acetone in hexanes eluent) to afford allylic alcohol $12(56 \mathrm{mg}, 56 \%$ yield) as an amorphous white solid: $\mathrm{R}_{f}=0.21$ (1:4 Acetone:Hexanes eluent); ${ }^{1} \mathrm{H}$ NMR $\left(\mathrm{CDCl}_{3}, 500 \mathrm{MHz}\right) \delta 6.32-6.24$ $(\mathrm{m}, 1 \mathrm{H}), 4.93-4.86(\mathrm{~m}, 1 \mathrm{H}), 4.74-4.70(\mathrm{~m}, 1 \mathrm{H}), 4.63(\mathrm{dt}, J=1.8$, $0.9 \mathrm{~Hz}, 1 \mathrm{H}), 3.37(\mathrm{dq}, J=6.0,2.9 \mathrm{~Hz}, 1 \mathrm{H}), 3.12(\mathrm{ddd}, J=15.9$, 9.7, $1.7 \mathrm{~Hz}, 1 \mathrm{H}), 2.99-2.89(\mathrm{~m}, 2 \mathrm{H}), 2.84(\mathrm{dq}, J=7.8,4.4 \mathrm{~Hz}$, $1 \mathrm{H}), 2.68$ (ddd, $J=15.1,3.2,2.3 \mathrm{~Hz}, 1 \mathrm{H}), 2.62$ (ddd, $J=15.2$, 6.0, $0.9 \mathrm{~Hz}, 1 \mathrm{H}), 2.40-2.29(\mathrm{~m}, 2 \mathrm{H}), 2.19$ (tt, $J=11.4,3.8 \mathrm{~Hz}$, $1 \mathrm{H}), 2.08(\mathrm{dd}, J=15.7,4.3 \mathrm{~Hz}, 1 \mathrm{H}), 2.02(\mathrm{~s}, 1 \mathrm{H}), 1.83(\mathrm{dtd}, J=$ $14.1,3.8,2.0 \mathrm{~Hz}, 1 \mathrm{H}), 1.74$ (dt, $J=1.5,0.7 \mathrm{~Hz}, 3 \mathrm{H}), 1.73-1.65$ $(\mathrm{m}, 1 \mathrm{H}), 1.35(\mathrm{~s}, 3 \mathrm{H}) ;{ }^{13} \mathrm{C}\left\{{ }^{1} \mathrm{H}\right\}$ NMR $\left(\mathrm{CDCl}_{3}, 126 \mathrm{MHz}\right) \delta$ 210.3, 174.8, 149.9, 146.2, 128.2, 113.0, 83.1, 79.4, 49.7, 49.4, 48.4, 45.8, 44.5, 40.0, 39.8, 32.4, 30.0, 26.9, 22.5; IR (Neat Film, $\mathrm{NaCl}) 3479,2965,1760,1699,1444,1372,1224,1138,992$, $900,754 \mathrm{~cm}^{-1}$; HRMS (FAB+) $\mathrm{m} / z$ calc'd for $\mathrm{C}_{19} \mathrm{H}_{25} \mathrm{O}_{4}[\mathrm{M}-\mathrm{H}]^{-}$: 315.1596, found 315.1600; $[\alpha]_{\mathrm{D}}^{25.0}-17.7^{\circ}\left(c 0.400, \mathrm{CHCl}_{3}\right)$.

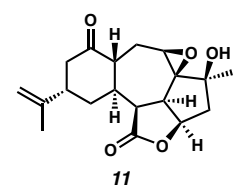

$\left(2 S, 2 \mathrm{a} S, 2 \mathrm{a}^{1} R, 3 \mathrm{a} R, 4 \mathrm{a} R, 7 S, 8 \mathrm{a} S, 8 \mathrm{~b} S, 10 \mathrm{a} R\right)-2-h y d r o x y-2-$ methyl-7-(prop-1-en-2yl)decahydrobenzo $[6,7]$ oxireno $\left[2^{\prime}, 3^{\prime}: 3 a, 4\right]$ azuleno $[1,8$ - 
bc]furan-5,9(2H,3aH)-dione (11). To a pale yellow stirred solution of allylic alcohol $12(50 \mathrm{mg}, 0.16 \mathrm{mmol}, 1.00$ equiv $)$ in a vial open to air in benzene $(5.3 \mathrm{~mL})$ was added $\mathrm{VO}(\mathrm{acac})_{2}(0.5$ $\mathrm{mg}, 0.0016 \mathrm{mmol}, 0.01$ equiv). After 5 minutes, to this dark green solution was added $t$-butyl hydroperoxide (TBHP, $36 \mathrm{~mL}$, $0.018 \mathrm{mmol}, 1.10$ equiv) as a $5 \mathrm{M}$ solution in decane dropwise causing the reaction to immediately became deep ruby red. After $1 \mathrm{~h}$, the reaction had lost all red color and become pale yellow and the consumption of starting material was complete as determined by TLC (1:4 Acetone:Hexanes eluent). The reaction was concentrated in vacuo and the crude tan solid was purified by silica gel column chromatography $(25 \%$ acetone in hexanes eluent) to afford epoxide 11 (47 mg, 94\% yield) as a white crystalline solid. Colorless, translucent X-ray quality crystals were obtained by slow diffusion of $1 \%$ benzene in heptane into a solution of epoxide 11 in EtOAc, mp: $183-185{ }^{\circ} \mathrm{C}: \mathrm{R}_{f}=0.15(1: 4$ Acetone:Hexanes eluent); ${ }^{1} \mathrm{H}$ NMR $\left(\mathrm{CDCl}_{3}, 600 \mathrm{MHz}\right) \delta 4.87$ (s, $1 \mathrm{H}), 4.79-4.73(\mathrm{~m}, 1 \mathrm{H}), 4.63-4.57(\mathrm{~m}, 1 \mathrm{H}), 3.34(\mathrm{~d}, J=7.1 \mathrm{~Hz}$, $1 \mathrm{H}), 3.24$ (ddd, $J=15.9,7.2,1.8 \mathrm{~Hz}, 1 \mathrm{H}), 3.05$ (dd, $J=6.0,4.4$ $\mathrm{Hz}, 1 \mathrm{H}), 2.97$ (ddd, $J=13.5,11.8,4.5 \mathrm{~Hz}, 1 \mathrm{H}), 2.84$ (dd, $J=6.5$, $3.4 \mathrm{~Hz}, 1 \mathrm{H}), 2.76(\mathrm{dd}, J=6.0,3.5 \mathrm{~Hz}, 1 \mathrm{H}), 2.67(\mathrm{~m}, 2 \mathrm{H}), 2.63$ $(\mathrm{dd}, J=15.3,6.0 \mathrm{~Hz}, 1 \mathrm{H}), 2.48$ (bs, $1 \mathrm{H}), 2.38(\mathrm{dd}, J=15.8,6.7$ $\mathrm{Hz}, 1 \mathrm{H}), 2.18(\mathrm{~d}, J=15.8 \mathrm{~Hz}, 1 \mathrm{H}), 1.89-1.74(\mathrm{~m}, 2 \mathrm{H}), 1.74(\mathrm{~s}$, $3 \mathrm{H}), 1.53(\mathrm{dd}, J=15.8,10.8 \mathrm{~Hz}, 1 \mathrm{H}), 1.31(\mathrm{~s}, 3 \mathrm{H}) ;{ }^{13} \mathrm{C}\left\{{ }^{1} \mathrm{H}\right\}$ NMR $\left(\mathrm{CDCl}_{3}, 126 \mathrm{MHz}\right) \delta 210.3,173.8,146.2,113.0,79.2$, 75.3, 71.4, 54.4, 46.8, 46.2, 45.3, 44.3, 44.2, 39.7, 38.0, 31.8, 26.3, 25.6, 22.4; IR (Neat Film, $\mathrm{NaCl}$ ) 3518, 2963, 2931, 1766, 1703, 1442, 1370, 1259, 1131, 985, 893, $758 \mathrm{~cm}^{-1}$; HRMS $(\mathrm{FAB}+) \mathrm{m} / \mathrm{z}$ calc'd for $\mathrm{C}_{19} \mathrm{H}_{25} \mathrm{O}_{5}[\mathrm{M}+\mathrm{H}]^{+}:$333.1702, found $333.1716 ;[\alpha]_{\mathrm{D}}{ }^{25.0}+13.2^{\circ}\left(c 0.200, \mathrm{CHCl}_{3}\right)$.

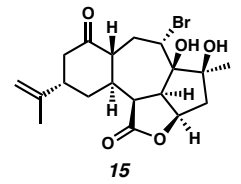

$\left(2 \mathrm{a} R, 2 \mathrm{a}^{1} R, 4 S, 4 \mathrm{a} R, 5 S, 6 \mathrm{a} R, 9 S, 10 \mathrm{a} S, 10 \mathrm{~b} S\right)-5$-bromo-4,4adihydroxy-4-methyl-9-(prop-1-en-2-yl)dodecahydro-1 $H$ benzo[6,7] azuleno[1,8-bc]furan-1,7(2aH)-dione (15). To a stirred colorless solution of epoxide $11(8 \mathrm{mg}, 0.024 \mathrm{mmol}, 1.00$ equiv) in a mixture of toluene $(1.6 \mathrm{~mL})$ and THF $(0.4 \mathrm{~mL})$ in a nitrogen-filled glovebox was added $\mathrm{MgBr}_{2}(22 \mathrm{mg}, 0.12 \mathrm{mmol}$, 5.00 equiv) in a single portion. The reaction mixture was then sealed and heated to $70{ }^{\circ} \mathrm{C}$. After $15 \mathrm{~h}$, the consumption of starting material was complete as determined by TLC (3:7 Acetone:Hexanes eluent). The golden yellow solution was removed from the glovebox. The reaction mixture was concentrated in vacuo and the crude tan solid was purified by silica gel column chromatography ( $20 \%$ acetone in hexanes eluent) to afford bromide 15 ( $8 \mathrm{mg}, 80 \%$ yield) as an amorphous white solid: $\mathrm{R}_{f}=$ 0.38 (3:7 Acetone:Hexanes eluent); ${ }^{1} \mathrm{H}$ NMR $\left(\mathrm{CDCl}_{3}, 600 \mathrm{MHz}\right)$ $\delta 4.96$ (ddd, $J=9.6,4.1,2.9 \mathrm{~Hz}, 1 \mathrm{H}), 4.89$ (dd, $J=2.2,1.1 \mathrm{~Hz}$, $1 \mathrm{H}), 4.80-4.74(\mathrm{~m}, 1 \mathrm{H}), 4.65(\mathrm{dt}, J=1.7,0.8 \mathrm{~Hz}, 1 \mathrm{H}), 3.17(\mathrm{~d}, J$ $=2.6 \mathrm{~Hz}, 1 \mathrm{H}), 2.88-2.70(\mathrm{~m}, 6 \mathrm{H}), 2.51(\mathrm{ddd}, J=14.6,6.5,1.0$ $\mathrm{Hz}, 1 \mathrm{H}), 2.39-2.31(\mathrm{~m}, 2 \mathrm{H}), 2.26(\mathrm{dd}, J=12.0,10.8 \mathrm{~Hz}, 1 \mathrm{H})$, $2.20(\mathrm{~d}, J=9.6 \mathrm{~Hz}, 1 \mathrm{H}), 2.15-2.09(\mathrm{~m}, 2 \mathrm{H}), 1.98(\mathrm{~s}, 3 \mathrm{H}), 1.88$ (tt, $J=12.5,3.1 \mathrm{~Hz}, 1 \mathrm{H}), 1.75(\mathrm{dt}, J=1.4,0.7 \mathrm{~Hz}, 3 \mathrm{H}), 1.61(\mathrm{dd}$, $J=11.4,4.4 \mathrm{~Hz}, 1 \mathrm{H}) ;{ }^{13} \mathrm{C}\left\{{ }^{1} \mathrm{H}\right\} \mathrm{NMR}\left(\mathrm{CDCl}_{3}, 126 \mathrm{MHz}\right) \delta$ 209.0, 176.1, 146.1, 113.3, 98.1, 72.5, 69.5, 68.4, 51.0, 49.9, 46.9, 46.8, 44.2, 43.2, 40.4, 33.7, 33.0, 26.1, 22.6; IR (Neat Film, $\mathrm{NaCl}) 3437,2926,1766,1708,1444,1262,1109,1014,799 \mathrm{~cm}^{-}$ ${ }^{1}$; HRMS (FAB+) $\mathrm{m} / \mathrm{z}$ calc'd for $\mathrm{C}_{19} \mathrm{H}_{26} \mathrm{O}_{5}{ }^{79} \mathrm{Br}[\mathrm{M}+\mathrm{H}]^{+}$: 413.0964, found 413.0965; $[\alpha]_{\mathrm{D}}^{25.0}-8.1^{\circ}\left(c 0.150, \mathrm{CHCl}_{3}\right)$.
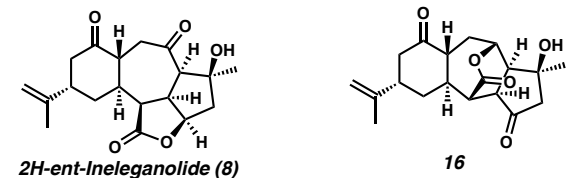

$\left(2 \mathrm{a} R, 2 \mathrm{a}^{1} R, 4 S, 4 \mathrm{a} R, 6 \mathrm{a} R, 9 S, 10 \mathrm{a} S, 10 \mathrm{~b} S\right)$-4-hydroxy-4-methyl9-(prop-1-en-2-yl)dodecahydro-1 $H$-benzo[6,7] azuleno[1,8bc]furan-1,5,7-trione (2H-ent-Ineleganolide, 8) and $(1 S, 3 \mathrm{a} R, 4 S, 4 \mathrm{a} S, 6 S, 8 \mathrm{a} R, 10 R, 10 \mathrm{a} S)-1-h y d r o x y-1-m e t h y l-6-$ (prop-1-en-2-yl)dodecahydro-10,4-

(epoxymethano)benzo[f]azulene-3,8,12-trione (16).

Preparation of 0.50 M Solution of Titanocene Monochloride ( $\left.\mathrm{Cp}_{2} \mathrm{TiCl}\right)$

Into a thoroughly flame-dried Schlenk tube under an overpressure of argon was charged with zinc $(0)$ dust $(647 \mathrm{mg}, 9.90$ mmol, 3.00 equiv) and titanocene dichloride $\left(\mathrm{Cp}_{2} \mathrm{TiCl}_{2}, 822 \mathrm{mg}\right.$, $3.30 \mathrm{mmol}, 1.00$ equiv). The flask was then evacuated and back filled with argon ( $3 \times 5$ minute cycles). To the reaction vessel was then added THF $(6.6 \mathrm{~mL})$ that had previously been sparged with argon for 60 minutes and stirring commenced. After $1.5 \mathrm{~h}$, the bright red reaction mixture had become dark green and stirring was halted. After 30 minutes, the supernatant was used as a $0.50 \mathrm{M}$ stock solution of $\mathrm{Cp}_{2} \mathrm{TiCl}$.

Reductive Opening of Epoxide 11

A stirred solution of epoxide 11 (26 mg, $0.078 \mathrm{mmol}, 1.00$ equiv) in THF $(2.5 \mathrm{~mL})$ was sparged with argon for $1 \mathrm{~h}$, resulting in a reaction volume of $1.5 \mathrm{~mL}$. The homogeneous, off-white reaction mixture was then cooled to $-78{ }^{\circ} \mathrm{C}(i-\mathrm{PrOH} / \mathrm{dry}$ ice bath) followed by the addition of $\mathrm{H}_{2} \mathrm{O}(108 \mu \mathrm{L}, 6.00 \mathrm{mmol}, 76.9$ equiv). After stirring for 5 minutes, $\mathrm{Cp}_{2} \mathrm{TiCl}(1.50 \mathrm{mmol}, 0.50 \mathrm{M}$ in THF, 19.2 equiv) was added dropwise over 8 minutes. After 2 $\mathrm{h}$, the reaction vessel was warmed to $0{ }^{\circ} \mathrm{C}$ (ice $/ \mathrm{H}_{2} \mathrm{O}$ bath). After an additional $1.5 \mathrm{~h}$, the Schlenk tube was removed from the cooling bath and allowed to warm to ambient temperature (ca. 23 ${ }^{\circ} \mathrm{C}$ ). After an additional $18.5 \mathrm{~h}$, the consumption of starting material was complete as determined by TLC (3:7 Acetone:Hexanes eluent). The reaction was quenched by the addition of saturated $\mathrm{NaH}_{2} \mathrm{PO}_{4}(1.0 \mathrm{~mL})$ and brine $(1.0 \mathrm{~mL})$, sparged with compressed air for 5 minutes, and allowed to stir for an additional 15 minutes. The reaction mixture was then filtered through a Celite ${ }^{\circledR}$ plug, washing with $50 \%$ acetone in hexanes eluent. The combined organics were concentrated in vacuo and immediately purified by silica gel column chromatography $(50 \%$ EtOAc in $\mathrm{CH}_{2} \mathrm{Cl}_{2}$ eluent), furnishing a mixture of diol products $(21 \mathrm{mg}$, $81 \%$ yield) that was directly carried on without further purification.

\section{Oxidation of Intermediate Diol Products}

To a portion of the diol products $(8 \mathrm{mg}, 0.024 \mathrm{mmol}, 1.00$ equiv) in wet $\mathrm{DCE}^{37}(3.0 \mathrm{~mL})$ was added DMP $(60 \mathrm{mg}, 0.14$ mmol, 5.82 equiv) at ambient temperature (ca. $23{ }^{\circ} \mathrm{C}$ ) with stirring. The reaction vessel was then sealed and heated to $65^{\circ} \mathrm{C}$. After $18 \mathrm{~h}$, the consumption of starting material was complete as determined by TLC (1:1 EtOAc: $\mathrm{CH}_{2} \mathrm{Cl}_{2}$ eluent). The reaction vessel was removed from the heating bath and allowed to cool to ambient temperature (ca. $23{ }^{\circ} \mathrm{C}$ ). The reaction mixture was then quenched by the addition of saturated $\mathrm{NaS}_{2} \mathrm{O}_{3}(3.0 \mathrm{~mL})$ and saturated $\mathrm{NaHCO}_{3}(3.0 \mathrm{~mL})$. After stirring to 10 minutes, the reaction mixture was diluted with $\mathrm{H}_{2} \mathrm{O}(10 \mathrm{~mL})$ and extracted with $\mathrm{CH}_{2} \mathrm{Cl}_{2}(3 \times 10 \mathrm{~mL})$. The combined organics were then dried over $\mathrm{MgSO}_{4}$, filtered, and concentrated in vacuo. The crude brown solid was purified by silica gel column chromatography ( $25 \%$ acetone in hexanes eluent) to furnish $2 \mathrm{H}$-ent-ineleganolide (8, $4 \mathrm{mg}, 50 \%$ yield) and diketone 16 (4 mg, 50\% yield), both as crystalline white solids.

2H-ent-Ineleganolide (8): Colorless, translucent X-ray quality crystals were obtained by slow diffusion of $1 \%$ benzene in 
heptane into a solution of $2 \mathrm{H}$-ent-ineleganolide (8) in EtOAc, mp: $218-220{ }^{\circ} \mathrm{C}: \mathrm{R}_{f}=0.23$ (3:7 Acetone:Hexanes eluent); ${ }^{1} \mathrm{H}$ NMR $\left(\mathrm{CDCl}_{3}, 500 \mathrm{MHz}\right) \delta 4.96-4.92(\mathrm{~m}, 1 \mathrm{H}), 4.80$ (ddd, $J=$ $7.2,6.2,3.8 \mathrm{~Hz}, 1 \mathrm{H}), 4.68(\mathrm{dt}, J=1.7,0.8 \mathrm{~Hz}, 1 \mathrm{H}), 3.62$ (q, $J=$ $1.3 \mathrm{~Hz}, 1 \mathrm{H}), 3.21(\mathrm{td}, J=9.3,6.2 \mathrm{~Hz}, 1 \mathrm{H}), 3.08(\mathrm{~d}, J=9.6 \mathrm{~Hz}$, $1 \mathrm{H}), 3.03(\mathrm{dd}, J=9.0,1.7 \mathrm{~Hz}, 1 \mathrm{H}), 2.96(\mathrm{dd}, J=11.6,3.8 \mathrm{~Hz}$, $1 \mathrm{H}), 2.89-2.78(\mathrm{~m}, 3 \mathrm{H}), 2.73(\mathrm{dt}, J=14.7,2.3 \mathrm{~Hz}, 1 \mathrm{H}), 2.67$ (ddd, $J=14.7,6.1,1.0 \mathrm{~Hz}, 1 \mathrm{H}), 2.51-2.37(\mathrm{~m}, 3 \mathrm{H}), 2.24-2.15$ $(\mathrm{m}, 1 \mathrm{H}), 1.91$ (ddd, $J=10.9,6.0,2.6 \mathrm{~Hz}, 1 \mathrm{H}), 1.78-1.74(\mathrm{~m}$, $3 \mathrm{H}), 1.28(\mathrm{t}, J=1.0 \mathrm{~Hz}, 3 \mathrm{H}) \cdot ;{ }^{13} \mathrm{C}\left\{{ }^{1} \mathrm{H}\right\} \mathrm{NMR}\left(\mathrm{CDCl}_{3}, 126 \mathrm{MHz}\right)$ $\delta 213.8,208.2,174.1,145.7,113.7,80.9,80.4,61.8,48.0,46.4$, 46.3, 46.1, 44.0, 43.2, 40.3, 37.0, 34.0, 28.7, 22.6; IR (Neat Film, $\mathrm{NaCl}) 3501,2965,2925,1761,1698,1440,1368,1318,1262$, 1160, 1081, 1030, 1003, 800, $758 \mathrm{~cm}^{-1}$; HRMS (FAB+) $\mathrm{m} / \mathrm{z}$ calc'd for $\mathrm{C}_{19} \mathrm{H}_{25} \mathrm{O}_{5}[\mathrm{M}+\mathrm{H}]^{+}: 333.1702$, found 333.1714; $[\alpha]_{\mathrm{D}}{ }^{25.0}$ $-32.6^{\circ}$ ( c $0.150, \mathrm{CHCl}_{3}$ ).

Diketone 16: Colorless, translucent $X$-ray quality crystals were obtained by slow diffusion of $1 \%$ benzene in heptane into a solution of diketone 16 in EtOAc, mp: $230-232{ }^{\circ} \mathrm{C}: \mathrm{R}_{f}=0.14$ (3:7 Acetone:Hexanes eluent); ${ }^{1} \mathrm{H}$ NMR $\left(\mathrm{CDCl}_{3}, 600 \mathrm{MHz}\right) \delta$ $5.28(\mathrm{~d}, J=9.2 \mathrm{~Hz}, 1 \mathrm{H}), 4.90(\mathrm{~d}, J=1.8 \mathrm{~Hz}, 1 \mathrm{H}), 4.66(\mathrm{~s}, 1 \mathrm{H})$, $3.02(\mathrm{~d}, J=1.8 \mathrm{~Hz}, 1 \mathrm{H}), 2.87(\mathrm{~d}, J=10.8 \mathrm{~Hz}, 1 \mathrm{H}), 2.84(\mathrm{~d}, J=$ $5.6 \mathrm{~Hz}, 1 \mathrm{H}), 2.72-2.62(\mathrm{~m}, 2 \mathrm{H}), 2.58-2.49(\mathrm{~m}, 2 \mathrm{H}), 2.45(\mathrm{~d}, J=$ $16.9 \mathrm{~Hz}, 1 \mathrm{H}), 2.41(\mathrm{~d}, J=10.8 \mathrm{~Hz}, 1 \mathrm{H}), 2.27(\mathrm{td}, J=12.5,5.4$ $\mathrm{Hz}, 1 \mathrm{H}), 2.13-2.07$ (m, 2H), $1.90(\mathrm{~s}, 1 \mathrm{H}), 1.82-1.70(\mathrm{~m}, 4 \mathrm{H})$, $1.71(\mathrm{dd}, J=15.0,12.1 \mathrm{~Hz}, 1 \mathrm{H}), 1.49(\mathrm{~s}, 3 \mathrm{H}) ;{ }^{13} \mathrm{C}\left\{{ }^{1} \mathrm{H}\right\} \mathrm{NMR}$ $\left(\mathrm{CDCl}_{3}, 126 \mathrm{MHz}\right) \delta 211.5,208.9,170.4,146.3,113.4,75.0$, 73.6, 53.1, 51.2, 50.1, 49.8, 47.5, 44.1, 41.7, 40.8, 34.4, 31.8, 28.7, 22.7; IR (Neat Film, NaCl) 3449, 2943, 1742, 1661, 1451, 1378, 1260, 1103, 1041, $801 \mathrm{~cm}^{-1}$; HRMS (EI+) $\mathrm{m} / z$ calc'd for $\mathrm{C}_{19} \mathrm{H}_{24} \mathrm{O}_{5}[\mathrm{M} \bullet]^{+}: 332.1624$, found $332.1620 ;[\alpha]_{\mathrm{D}}{ }^{25.0}+7.8^{\circ}(c$ $\left.0.100, \mathrm{CHCl}_{3}\right)$.

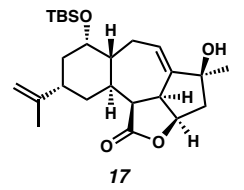

$\left(2 \mathrm{a} R, 2 \mathrm{a}^{1} S, 4 S, 6 \mathrm{a} R, 7 S, 9 S, 10 \mathrm{a} S, 10 \mathrm{~b} S\right)-7-((t e r t-$ butyldimethylsilyl)oxy)-4-hydroxy-4-methyl-9-(prop-1-en-2yl)-2a, $2 \mathrm{a}^{1}, 3,4,6,6 \mathrm{a}, 7,8,9,10,10 \mathrm{a}, 10 \mathrm{~b}$-dodecahydro- $1 H$ -

benzo[6,7]azuleno[1,8-bc]furan-1-one (17). To a stirred colorless solution of ketone $\mathbf{1 2}(10 \mathrm{mg}, 0.032 \mathrm{mmol}, 1.00$ equiv) in THF $(2.50 \mathrm{~mL})$ at $-78{ }^{\circ} \mathrm{C}(i$-PrOH/dry ice bath $)$ was added LSelectride $^{\circledR}(100 \mathrm{~mL}, 1.0 \mathrm{M}$ in THF, 3.00 equiv) slowly dropwise over 2 minutes. After 15 minutes, the consumption of starting material was complete as determined by TLC (3:7 Acetone:Hexanes eluent). The light yellow reaction mixture was quenched by the addition of saturated $\mathrm{NH}_{4} \mathrm{Cl}(2.00 \mathrm{~mL})$, removed from the cooling bath, and allowed to warm to ambient temperature (ca. $23{ }^{\circ} \mathrm{C}$ ). The reaction mixture was then diluted with $\mathrm{H}_{2} \mathrm{O}(10 \mathrm{~mL})$ and extracted with EtOAc $(3 \times 8 \mathrm{~mL})$. The combined organics were then dried over $\mathrm{MgSO}_{4}$, filtered, and concentrated in vacuo to afford an amorphous white solid that was carried on without further purification, assuming quantitative yield.

To a solution of the crude white solid in $\mathrm{CH}_{2} \mathrm{Cl}_{2}(0.65 \mathrm{~mL})$ were added imidazole ( $22 \mathrm{mg}, 0.32 \mathrm{mmol}, 10.0$ equiv) and DMAP $(0.7 \mathrm{mg}, 0.006 \mathrm{mmol}, 0.20$ equiv) at ambient temperature (ca. $23{ }^{\circ} \mathrm{C}$ ). The pale yellow reaction mixture was the cooled to 0 ${ }^{\circ} \mathrm{C}$ (ice/ $\mathrm{H}_{2} \mathrm{O}$ bath) at which time TBSCl $(15 \mathrm{mg}, 0.096 \mathrm{mmol}$, 3.00 equiv) was added as a solution in $\mathrm{CH}_{2} \mathrm{Cl}_{2}(0.25 \mathrm{~mL})$ quickly dropwise. After 15 minutes, the reaction was removed from the cooling bath and allowed to warm to ambient temperature (ca. 23 $\left.{ }^{\circ} \mathrm{C}\right)$. After $18 \mathrm{~h}$, additional imidazole $(50 \mathrm{mg}, 0.74 \mathrm{mmol}, 23.1$ equiv), DMAP (10 mg, 0.082, 2.56 equiv), and TBSCl (30 mg, $0.20 \mathrm{mmol}, 6.35$ equiv) were added sequentially as solids, each in a single portion. After $6 \mathrm{~h}$, the consumption of starting material was complete as determined by TLC (3:7 Acetone:Hexanes eluent). The reaction mixture was concentrated in vacuo and the resultant crude white solid was purified by silica gel column chromatography ( $15 \%$ acetone in hexanes eluent) to provide silyl ether 17 (79\% yield, 2 steps) as an amorphous white solid: $\mathrm{R}_{f}=$ 0.19 (3:17 Acetone:Hexanes eluent); ${ }^{1} \mathrm{H}$ NMR $\left(\mathrm{CDCl}_{3}, 400\right.$ MHz) $\delta 6.30(\mathrm{ddd}, J=8.8,5.0,2.9 \mathrm{~Hz}, 1 \mathrm{H}), 4.77-4.64(\mathrm{~m}, 3 \mathrm{H})$, $3.86(\mathrm{dt}, J=4.9,2.6 \mathrm{~Hz}, 1 \mathrm{H}), 3.36(\mathrm{tt}, J=5.9,2.6 \mathrm{~Hz}, 1 \mathrm{H}), 2.97$ $(\mathrm{dd}, J=5.7,3.9 \mathrm{~Hz}, 1 \mathrm{H}), 2.77-2.66(\mathrm{~m}, 1 \mathrm{H}), 2.45-2.32(\mathrm{~m}, 2 \mathrm{H})$, 2.14-2.00 (m, 4H), 1.99-1.82 (m, 3H), 1.74 (dt, $J=1.2,0.6 \mathrm{~Hz}$, $3 \mathrm{H}), 1.73-1.66(\mathrm{~m}, 1 \mathrm{H}), 1.61(\mathrm{tt}, J=11.0,3.1 \mathrm{~Hz}, 1 \mathrm{H}), 1.37(\mathrm{~s}$, $3 \mathrm{H}), 0.88(\mathrm{~s}, 9 \mathrm{H}), 0.07(\mathrm{~s}, 3 \mathrm{H}), 0.03(\mathrm{~s}, 3 \mathrm{H}) ;{ }^{13} \mathrm{C}\left\{{ }^{1} \mathrm{H}\right\} \mathrm{NMR}$ $\left(\mathrm{CDCl}_{3}, 101 \mathrm{MHz}\right) \delta 175.4,149.7,149.0,129.9,108.3,83.0$, $79.4,73.1,50.3,50.2,45.9,39.7,36.6,36.5,35.2,33.4,32.8$, 29.7, 26.1, 21.9, 18.2, -3.9, -4.5; IR (Neat Film, NaCl) 3501, 2927, 2855, 1767, 1444, 1360, 1256, 1151, 1069, 1003, 959, 836, 807, $773 \mathrm{~cm}^{-1}$; HRMS (FAB+) $\mathrm{m} / z$ calc'd for $\mathrm{C}_{25} \mathrm{H}_{39} \mathrm{O}_{4} \mathrm{Si}$ $\left[(\mathrm{M}+\mathrm{H})-\mathrm{H}_{2}\right]^{+}:$431.2618, found 431.2611; $[\alpha]_{\mathrm{D}}{ }^{25.0}-8.1^{\circ}(c$ $\left.0.250, \mathrm{CHCl}_{3}\right)$.

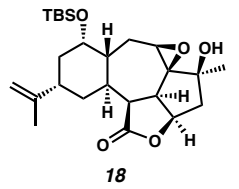

$\left(2 S, 2 \mathrm{a} S, 2 \mathrm{a}^{1} R, 3 \mathrm{a} R, 4 \mathrm{a} R, 5 S, 7 S, 8 \mathrm{a} S, 8 \mathrm{~b} S, 10 \mathrm{a} R\right)-5-((t e r t-$ butyldimethylsilyl)oxy)-2-hydroxy-2-methyl-7-(prop-1-en-2yl)dodecahydrobenzo $[6,7]$ oxireno $\left[2^{\prime}, 3^{\prime}: 3 \mathrm{a}, 4\right]$ azuleno $[1,8-$

bc]furan-9(2H)-one (18). To a pale yellow stirred solution of allylic alcohol $17(5 \mathrm{mg}, 0.012 \mathrm{mmol}, 1.00$ equiv) in a vial open to air in benzene $(2.0 \mathrm{~mL})$ was added $\mathrm{VO}(\mathrm{acac})_{2}(0.6 \mathrm{mg}, 0.0024$ mmol, 0.2 equiv). After 5 minutes, to this dark green solution was added $t$-butyl hydroperoxide (TBHP, $3 \mathrm{~mL}, 0.014 \mathrm{mmol}$, 1.10 equiv) as a $5 \mathrm{M}$ solution in decane dropwise causing the reaction to immediately become deep ruby red. After $1.5 \mathrm{~h}$, the reaction had lost all red color and become pale yellow and the consumption of starting material was complete as determined by TLC (3:17 Acetone:Hexanes eluent). The reaction was concentrated in vacuo and the crude tan solid was purified by silica gel column chromatography ( $15 \%$ acetone in hexanes eluent) to afford epoxide 18 (4 mg, 80\% yield) as an amorphous white solid: $\mathrm{R}_{f}=0.19$ (3:17 Acetone:Hexanes eluent); ${ }^{1} \mathrm{H}$ NMR $\left(\mathrm{CDCl}_{3}, 400\right.$ MHz) $\delta 4.74$ (ddd, $J=6.6,4.5,1.3 \mathrm{~Hz}, 1 \mathrm{H}), 4.68$ (qt, $J=1.9,0.9$ $\mathrm{Hz}, 2 \mathrm{H}), 3.87(\mathrm{dt}, J=5.0,1.7 \mathrm{~Hz}, 1 \mathrm{H}), 3.28(\mathrm{~d}, J=6.8 \mathrm{~Hz}, 1 \mathrm{H})$, $3.04(\mathrm{dd}, J=6.0,4.5 \mathrm{~Hz}, 1 \mathrm{H}), 2.79$ (dd, $J=6.2,2.7 \mathrm{~Hz}, 2 \mathrm{H})$, $2.53(\mathrm{~d}, J=1.2 \mathrm{~Hz}, 1 \mathrm{H}), 2.37(\mathrm{dd}, J=15.7,6.6 \mathrm{~Hz}, 1 \mathrm{H}), 2.17(\mathrm{~d}$, $J=15.7 \mathrm{~Hz}, 1 \mathrm{H}), 2.11(\mathrm{dd}, J=13.5,6.9 \mathrm{~Hz}, 1 \mathrm{H}), 2.03-1.83(\mathrm{~m}$, 6H), 1.76-1.69 (m, 3H), 1.64 (ddd, $J=14.3,7.8,2.1 \mathrm{~Hz}, 1 \mathrm{H})$, $1.35-1.30(\mathrm{~m}, 3 \mathrm{H}), 0.88(\mathrm{~s}, 9 \mathrm{H}), 0.07(\mathrm{~s}, 3 \mathrm{H}), 0.04(\mathrm{~s}, 3 \mathrm{H})$; ${ }^{13} \mathrm{C}\left\{{ }^{1} \mathrm{H}\right\}$ NMR $\left(\mathrm{CDCl}_{3}, 101 \mathrm{MHz}\right) \delta 174.3,149.7,108.3,79.0$, 77.4, 75.4, 73.6, 71.5, 55.4, 48.4, 45.5, 44.8, 36.6, 36.4, 35.4, 33.5, 32.7, 32.3, 26.1, 25.6, 21.7, 18.1, -3.9, -4.5; IR (Neat Film, $\mathrm{NaCl}) 3521,2928,2856,1771,1645,1463,1361,1257,1163$, $1069,986,963,878,836,774 \mathrm{~cm}^{-1}$; HRMS (FAB+) $\mathrm{m} / z$ calc'd for $\mathrm{C}_{25} \mathrm{H}_{39} \mathrm{O}_{5} \mathrm{Si}\left[(\mathrm{M}+\mathrm{H})-\mathrm{H}_{2}\right]^{+}:$447.2567, found 447.2572; $[\alpha]_{\mathrm{D}}^{25.0}+19.9^{\circ}\left(c 0.200, \mathrm{CHCl}_{3}\right)$.

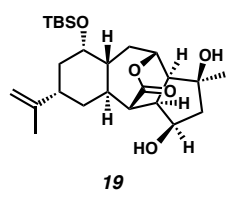


$(1 S, 3 R, 3 \mathrm{a} R, 4 S, 4 \mathrm{a} S, 6 S, 8 S, 8 \mathrm{a} R, 10 R, 10 \mathrm{a} S)-8-(($ tertbutyldimethylsilyl)oxy)-1,3-dihydroxy-1-methyl-6-(prop-1en-2-yl)tetradecahydro-10,4-(epoxymethano)benzo[ $f$ azulen12-one (19).

Preparation of $0.50 \mathrm{M}$ Solution of Titanocene Monochloride $\left(\mathrm{Cp}_{2} \mathrm{TiCl}\right)$

Into a thoroughly flame-dried Schlenk tube under an overpressure of argon was charged with zinc(0) dust $(647 \mathrm{mg}, 9.90$ mmol, 3.00 equiv) and titanocene dichloride $\left(\mathrm{Cp}_{2} \mathrm{TiCl}_{2}, 822 \mathrm{mg}\right.$, $3.30 \mathrm{mmol}, 1.00$ equiv). The flask was then evacuated and back filled with argon ( 3 x 5 minute cycles). To the reaction vessel was then added THF $(6.6 \mathrm{~mL})$ that had previously been sparged with argon for 60 minutes and stirring commenced. After $1.5 \mathrm{~h}$, the bright red reaction mixture had become dark green and stirring was halted. After 30 minutes, the supernatant was used as a $0.50 \mathrm{M}$ stock solution of $\mathrm{Cp}_{2} \mathrm{TiCl}$.

Epoxide Opening with $\mathrm{Cp}_{2} \mathrm{TiCl}$

A stirred solution of epoxide $18(5 \mathrm{mg}, 0.013 \mathrm{mmol}, 1.00$ equiv) in THF $(1.5 \mathrm{~mL})$ was sparged with argon for $1 \mathrm{~h}$, resulting in a reaction volume of $0.5 \mathrm{~mL}$. The homogeneous, off-white reaction mixture was then cooled to $-78{ }^{\circ} \mathrm{C}(i-\mathrm{PrOH} / \mathrm{dry}$ ice bath) followed by the addition of $\mathrm{H}_{2} \mathrm{O}(18 \mu \mathrm{L}, 1.00 \mathrm{mmol}, 76.9$ equiv). After stirring for 5 minutes, $\mathrm{Cp}_{2} \mathrm{TiCl}(0.25 \mathrm{mmol}, 0.50 \mathrm{M}$ in THF, 19.2 equiv) was added dropwise over 3 minutes. After 2 $\mathrm{h}$, the reaction vessel was warmed to $0{ }^{\circ} \mathrm{C}$ (ice $/ \mathrm{H}_{2} \mathrm{O}$ bath). After an additional $2.5 \mathrm{~h}$, the Schlenk tube was removed from the cooling bath and allowed to warm to ambient temperature. After an additional $12 \mathrm{~h}$, the consumption of starting material was complete as determined by TLC (3:17 Acetone:Hexanes eluent). The reaction was quenched by the addition of saturated $\mathrm{NaH}_{2} \mathrm{PO}_{4}$ $(0.25 \mathrm{~mL})$ and brine $(0.25 \mathrm{~mL})$, sparged with compressed air for 5 minutes, and allowed to stir for an additional 15 minutes. The reaction mixture was then filtered through a Celite ${ }^{\circledR}$ plug, washing with $50 \%$ acetone in hexanes eluent. The combined organics were concentrated in vacuo and immediately purified by silica gel column chromatography ( $40 \%$ EtOAc in $\mathrm{CH}_{2} \mathrm{Cl}_{2}$ eluent) to furnish diol 19 (4 mg, 66\% yield) as an amorphous white solid: $\mathrm{R}_{f}=0.42$ (1:1 EtOAc: $\mathrm{CH}_{2} \mathrm{Cl}_{2}$ eluent); ${ }^{1} \mathrm{H}$ NMR $\left(\mathrm{CDCl}_{3}, 400\right.$ MHz) $\delta 4.92(\mathrm{~d}, J=8.7 \mathrm{~Hz}, 1 \mathrm{H}), 4.69(\mathrm{t}, J=1.8 \mathrm{~Hz}, 1 \mathrm{H}), 4.67$ $(\mathrm{q}, J=1.6 \mathrm{~Hz}, 1 \mathrm{H}), 4.33(\mathrm{q}, J=4.3 \mathrm{~Hz}, 1 \mathrm{H}), 3.72(\mathrm{q}, J=2.8 \mathrm{~Hz}$, $1 \mathrm{H}), 3.20(\mathrm{~s}, 1 \mathrm{H}), 2.67-2.58(\mathrm{~m}, 2 \mathrm{H}), 2.50(\mathrm{~d}, J=5.1 \mathrm{~Hz}, 1 \mathrm{H})$, 2.28-2.20 (m, 1H), 2.19-2.05 (m, 2H), 2.05-1.91 (m, 4H), 1.75$1.66(\mathrm{~m}, 5 \mathrm{H}), 1.64-1.52(\mathrm{~m}, 2 \mathrm{H}), 1.34$ (dddd, $J=12.1,9.0,6.0$, $2.9 \mathrm{~Hz}, 1 \mathrm{H}), 1.28(\mathrm{~s}, 3 \mathrm{H}), 0.80(\mathrm{~s}, 9 \mathrm{H}), 0.00(\mathrm{~d}, J=3.0 \mathrm{~Hz}, 3 \mathrm{H})$, $-0.06(\mathrm{~s}, 3 \mathrm{H}) ;{ }^{13} \mathrm{C}\left\{{ }^{1} \mathrm{H}\right\} \mathrm{NMR}\left(\mathrm{CDCl}_{3}, 101 \mathrm{MHz}\right) \delta 174.76$, $148.41,108.35,81.39,76.21,74.16,70.00,52.77,50.22,48.81$, $48.35,42.47,37.26,36.95,35.81,34.91,34.69,27.47,25.95$, 23.23, 18.18, -3.84, -4.81.; IR (Neat Film, NaCl) 3391, 2927, 2855, 1726, 1444, 1386, 1252, 1173, 1081, 1056, 881 838, 774 $\mathrm{cm}^{-1}$; HRMS (FAB+) $\mathrm{m} / \mathrm{z}$ calc'd for $\mathrm{C}_{25} \mathrm{H}_{43} \mathrm{O}_{5} \mathrm{Si}[\mathrm{M}+\mathrm{H}]^{+}$: 451.2880, found 451.2890; $[\alpha]_{\mathrm{D}}^{25.0}-2.9^{\circ}\left(c 0.200, \mathrm{CHCl}_{3}\right)$.

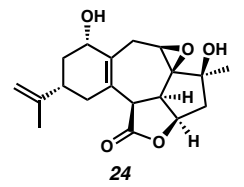

$\left(2 S, 2 \mathrm{a} S, 2 \mathrm{a}^{1} R, 3 \mathrm{a} R, 5 S, 7 S, 8 \mathrm{~b} R, 10 \mathrm{a} R\right)-2,5$-dihydroxy-2methyl-7-(prop-1-en-2-yl)-1,2a ${ }^{1}, 3 \mathrm{a}, 4,5,6,7,8,8 \mathrm{~b}, 10 \mathrm{a}-$ decahydrobenzo $[6,7]$ oxireno $\left[2^{\prime}, 3^{\prime}: 3 \mathrm{a}, 4\right]$ azuleno $[1,8-b c]$ furan9(2H)-one (24). To a stirred solution of ent-isoineleganolide A (13, $11 \mathrm{mg}, 0.033 \mathrm{mmol}, 1.00$ equiv) in $\mathrm{MeOH}(0.3 \mathrm{~mL})$ and $\mathrm{CH}_{2} \mathrm{Cl}_{2}(0.3 \mathrm{~mL})$ at $-78{ }^{\circ} \mathrm{C}(i$-PrOH$/$ dry ice bath $)$ was added $\mathrm{NaBH}_{4}$ (4 mg, $0.10 \mathrm{mmol}, 3.00$ equiv) as a solid in single portion. After $1 \mathrm{~h}$, the homogenous colorless reaction mixture was warmed to $0{ }^{\circ} \mathrm{C}$ (ice/ $\mathrm{H}_{2} \mathrm{O}$ bath). After an additional $1 \mathrm{~h}$, the consumption of starting material was complete as determined by TLC (1:4 EtOAc: $\mathrm{CH}_{2} \mathrm{Cl}_{2}$ eluent). The reaction was quenched by the addition of saturated aqueous $\mathrm{NaHCO}_{3}(80 \mathrm{~mL})$, removed from the cooling bath, and allowed to warm to ambient temperature (ca. $23{ }^{\circ} \mathrm{C}$ ). The reaction mixture was then filtered through a silica gel plug, eluting with EtOAc. The combined organics were concentrated in vacuo. The crude white solid was purified by silica gel column chromatography $(95 \%$ EtOAc in hexanes eluent) to provide allylic alcohol $24(11 \mathrm{mg},>99 \%$ yield) as an amorphous white solid: $\mathrm{R}_{f}=0.17$ (19:1 EtOAc:Hexanes eluent); ${ }^{1} \mathrm{H}$ NMR $\left(\mathrm{CDCl}_{3}, 600 \mathrm{MHz}\right) \delta 4.79-4.68(\mathrm{~m}, 3 \mathrm{H}), 4.21(\mathrm{t}, J=$ $8.3 \mathrm{~Hz}, 1 \mathrm{H}), 3.35(\mathrm{dd}, J=6.1,4.5 \mathrm{~Hz}, 1 \mathrm{H}), 3.32(\mathrm{~d}, J=5.2 \mathrm{~Hz}$, $1 \mathrm{H}), 3.21(\mathrm{~d}, J=6.1 \mathrm{~Hz}, 1 \mathrm{H}), 3.01-2.93(\mathrm{~m}, 1 \mathrm{H}), 2.92-2.84(\mathrm{~m}$, 2H), 2.42-2.32 (m, 2H), 2.29 (d, $J=16.0 \mathrm{~Hz}, 1 \mathrm{H}), 2.22-2.15$ (m, 1H), 1.79-1.70 (m, 4H), $1.42(\mathrm{td}, J=12.3,9.7 \mathrm{~Hz}, 1 \mathrm{H}), 1.33$ $(\mathrm{s}, 3 \mathrm{H}) ;{ }^{13} \mathrm{C}\left\{{ }^{1} \mathrm{H}\right\} \mathrm{NMR}\left(\mathrm{CDCl}_{3}, 126 \mathrm{MHz}\right) \delta 173.8,148.4,129.7$, 126.8, 109.4, 79.6, 75.2, 73.8, 70.4, 55.5, 48.8, 45.7, 44.1, 38.5, 38.1, 37.2, 28.0, 26.5, 21.0; IR (Neat Film, NaCl) 3441, 2930, $1771,1645,1436,1373,1234,1140,986,890,757 \mathrm{~cm}^{-1}$; HRMS $(\mathrm{FAB}+) \mathrm{m} / z$ calc'd for $\mathrm{C}_{19} \mathrm{H}_{25} \mathrm{O}_{5}[\mathrm{M}+\mathrm{H}]^{+}:$333.1702, found $333.1695 ;[\alpha]_{\mathrm{D}}^{25.0}+0.5^{\circ}\left(c 0.550, \mathrm{CHCl}_{3}\right)$.

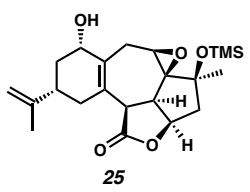

$\left(2 S, 2 \mathrm{a} S, 2 \mathrm{a}^{1} R, 3 \mathrm{a} R, 5 S, 7 S, 8 \mathrm{~b} R, 10 \mathrm{a} R\right)-5$-hydroxy-2-methyl-7(prop-1-en-2-yl)-2-((trimethylsilyl)oxy)$1,2 \mathrm{a}^{1}, 3 \mathrm{a}, 4,5,6,7,8,8 \mathrm{~b}, 10 \mathrm{a}-$ decahydrobenzo[6,7]oxireno $\left[2^{\prime}, 3^{\prime}: 3 a, 4\right]$ azuleno[1,8-bc]furan9(2H)-one (25). To a stirred solution of allylic alcohol 24 (11 $\mathrm{mg}, 0.033 \mathrm{mmol}, 1.00$ equiv) in $\mathrm{CH}_{2} \mathrm{Cl}_{2}(0.7 \mathrm{~mL})$ at $-78{ }^{\circ} \mathrm{C}(i-$ $\mathrm{PrOH} /$ dry ice bath) was added $\mathrm{Et}_{3} \mathrm{~N}(92 \mathrm{ml}, 0.66 \mathrm{mmol}, 20.0$ equiv) dropwise. After 5 minutes, TMSOTf $(31 \mathrm{~mL}, 0.10 \mathrm{mmol}$, 3.00 equiv) was added slowly dropwise. After an additional 10 minutes, the consumption of starting material was complete as determined by TLC (19:1 EtOAc:Hexanes eluent). The reaction was quenched by the addition of saturated aqueous $\mathrm{NaHCO}_{3}(80$ $\mathrm{mL}$ ), removed from the cooling bath, and allowed to warm to ambient temperature (ca. $23{ }^{\circ} \mathrm{C}$ ). The reaction mixture was then filtered through a silica gel plug, eluting with $100 \%$ EtOAc. The combined organics were concentrated in vacuo. The crude white solid was purified by silica gel column chromatography $(40 \%$ EtOAc in hexanes eluent) to furnish silyl ether $25(10 \mathrm{mg}, 77 \%$ yield) as an amorphous white solid: $\mathrm{R}_{f}=0.36$ (1:1 EtOAc:Hexanes eluent); ${ }^{1} \mathrm{H}$ NMR $\left(\mathrm{CDCl}_{3}, 600 \mathrm{MHz}\right) \delta 4.83-$ $4.67(\mathrm{~m}, 3 \mathrm{H}), 4.33-4.22(\mathrm{~m}, 1 \mathrm{H}), 3.35-3.30(\mathrm{~m}, 2 \mathrm{H}), 3.17(\mathrm{~d}, J=$ $6.2 \mathrm{~Hz}, 1 \mathrm{H}), 3.00-2.90(\mathrm{~m}, 1 \mathrm{H}), 2.83$ (ddt, $J=16.6,4.0,2.1 \mathrm{~Hz}$, 1H), 2.68 (dd, $J=19.7,5.5 \mathrm{~Hz}, 1 \mathrm{H}), 2.55$ (bs, $1 \mathrm{H}), 2.44-2.25$ (m, 3H), 2.13-2.04 (m, 1H), 1.83-1.69 (m, 4H), 1.48-1.38 (m, 1H), $1.33(\mathrm{~s}, 3 \mathrm{H}), 0.18(\mathrm{~s}, 9 \mathrm{H}) ;{ }^{13} \mathrm{C}\left\{{ }^{1} \mathrm{H}\right\}$ NMR $\left(\mathrm{CDCl}_{3}, 126\right.$ MHz) $\delta 173.8,148.4,129.8,127.0,109.4,79.6(\mathrm{~d}, J=4.1 \mathrm{~Hz})$, 75.2, 74.8, 70.4, 55.6, 48.8, 45.7, 44.2, 38.6, 38.4, 37.3, 28.5, 26.5, 20.8, 0.6; IR (Neat Film, NaCl) 3429, 2959, 1764, 1371, $1250,1142,1056,887,841 \mathrm{~cm}^{-1}$; HRMS (FAB+) $\mathrm{m} / z$ calc'd for $\mathrm{C}_{22} \mathrm{H}_{33} \mathrm{O}_{5} \mathrm{Si}[\mathrm{M}+\mathrm{H}]^{+}:$405.2097, found 405.2088; $[\alpha]_{\mathrm{D}}{ }^{25.0}+60.4^{\circ}$ (c $0.250, \mathrm{CHCl}_{3}$ ).

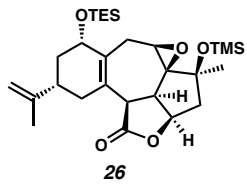


$\left(2 S, 2 \mathrm{a} S, 2 \mathrm{a}^{1} R, 3 \mathrm{a} R, 5 S, 7 S, 8 \mathrm{~b} R, 10 \mathrm{a} R\right)-2$-methyl-7-(prop-1-en2-yl)-5-((triethylsilyl)oxy)-2-((trimethylsilyl)oxy)-

\section{$1,2 a^{1}, 3 a, 4,5,6,7,8,8 b, 10 a-$}

decahydrobenzo[6,7]oxireno[2',3':3a,4] azuleno[1,8-bc]furan9(2H)-one (26). To a stirred solution of allylic alcohol $25(5 \mathrm{mg}$, $0.012 \mathrm{mmol}, 1.00$ equiv) in $\mathrm{CH}_{2} \mathrm{Cl}_{2}(0.3 \mathrm{~mL})$ at $-78{ }^{\circ} \mathrm{C}(i-$ $\mathrm{PrOH} /$ dry ice bath) was added $\mathrm{Et}_{3} \mathrm{~N}(35 \mathrm{ml}, 0.25 \mathrm{mmol}, 20.8$ equiv) dropwise. After 5 minutes, TESOTf $(15 \mathrm{~mL}, 0.060 \mathrm{mmol}$, 5.00 equiv) was added slowly dropwise. After an additional 20 minutes, the consumption of starting material was complete as determined by TLC (1:1 EtOAc:Hexanes eluent). The reaction was quenched by the addition of saturated aqueous $\mathrm{NaHCO}_{3}(80$ $\mathrm{mL}$ ), removed from the cooling bath, and allowed to warm to ambient temperature $\left(\mathrm{ca} .23{ }^{\circ} \mathrm{C}\right.$ ). The reaction mixture was then filtered through a silica gel plug, eluting with EtOAc. The combined organics were concentrated in vacuo. The crude white solid was purified by silica gel column chromatography $(10 \%$ EtOAc in hexanes eluent) to afford bis-silyl ether $\mathbf{2 6}$ (4 mg, 66\% yield) as an amorphous white solid: $\mathrm{R}_{f}=0.14$ (1:9 EtOAc:Hexanes eluent); ${ }^{1} \mathrm{H}$ NMR $\left(\mathrm{CDCl}_{3}, 600 \mathrm{MHz}\right) \delta 4.84$ $4.72(\mathrm{~m}, 2 \mathrm{H}), 4.70(\mathrm{~s}, 1 \mathrm{H}), 4.33-4.21(\mathrm{~m}, 1 \mathrm{H}), 3.25(\mathrm{dd}, J=6.4$, $4.7 \mathrm{~Hz}, 1 \mathrm{H}), 3.20(\mathrm{~d}, J=5.4 \mathrm{~Hz}, 1 \mathrm{H}), 3.10(\mathrm{~d}, J=6.4 \mathrm{~Hz}, 1 \mathrm{H})$, 2.93-2.84 (m, 2H), $2.65(\mathrm{dd}, J=19.5,5.5 \mathrm{~Hz}, 1 \mathrm{H}), 2.41-2.32$ (m, 2H), 2.28 (dd, $J=15.0,6.5 \mathrm{~Hz}, 1 \mathrm{H}), 2.10-2.03(\mathrm{~m}, 1 \mathrm{H})$, $1.76-1.70(\mathrm{~m}, 4 \mathrm{H}), 1.41(\mathrm{td}, J=12.7,10.0 \mathrm{~Hz}, 1 \mathrm{H}), 1.31(\mathrm{~s}, 3 \mathrm{H})$, $0.93(\mathrm{t}, J=7.9 \mathrm{~Hz}, 9 \mathrm{H}), 0.68-0.54(\mathrm{~m}, 6 \mathrm{H}), 0.18(\mathrm{~s}, 9 \mathrm{H})$; ${ }^{13} \mathrm{C}\left\{{ }^{1} \mathrm{H}\right\}$ NMR $\left(\mathrm{CDCl}_{3}, 126 \mathrm{MHz}\right) \delta 173.7,148.6,130.0,127.0$, $109.3,79.3,77.0,74.9,69.6,53.8,48.6,44.5,43.4,38.6,38.5$, 37.2, 29.7, 28.7, 20.8, 7.2, 6.5, 0.6; IR (Neat Film, NaCl) 3464, 2956, 1766, 1665, 1451, 1376, 1249, 1143, 1047, 890, 841, 795, $744 \mathrm{~cm}^{-1}$; HRMS (FAB+) $m / z$ calc'd for $\mathrm{C}_{28} \mathrm{H}_{47} \mathrm{O}_{5} \mathrm{Si}_{2}[\mathrm{M}+\mathrm{H}]^{+}$: 519.2962, found 519.2959; $[\alpha]_{\mathrm{D}}^{25.0}+53.6^{\circ}\left(c 0.100, \mathrm{CHCl}_{3}\right)$.
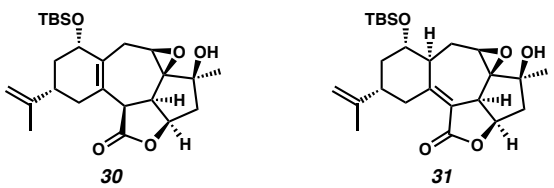

$\left(2 S, 2 \mathrm{a} S, 2 \mathrm{a}^{1} R, 3 \mathrm{a} R, 5 S, 7 S, 8 \mathrm{~b} R, 10 \mathrm{a} R\right)-5-((t e r t-$ butyldimethylsilyl)oxy)-2-hydroxy-2-methyl-7-(prop-1-en-2yl)-1,2a ${ }^{1}, 3 a, 4,5,6,7,8,8 b, 10 a-$

decahydrobenzo[6,7]oxireno[ $\left[2^{\prime}, 3^{\prime}: 3 \mathrm{a}, 4\right]$ azuleno[1,8-bc] furan9(2H)-one (30) and $\left(2 S, 2 \mathrm{a} S, 2 \mathrm{a}^{1} R, 3 \mathrm{a} R, 4 \mathrm{a} S, 5 S, 7 S, 10 \mathrm{a} R\right)-5$ ((tert-butyldimethylsilyl)oxy)-2-hydroxy-2-methyl-7-(prop-1en-2-yl)-1,2a ${ }^{1}, 3 a, 4,4 a, 5,6,7,8,10 a-$

decahydrobenzo[6,7]oxireno[ $\left[2^{\prime}, 3^{\prime}: 3 a, 4\right]$ azuleno[1,8-bc] furan$\mathbf{9}(\mathbf{2 H})$-one (31). To a stirred solution of allylic alcohol 24 (65 $\mathrm{mg}, 0.20 \mathrm{mmol}, 1.00$ equiv) in $\mathrm{CH}_{2} \mathrm{Cl}_{2}(20 \mathrm{~mL})$ were added imidazole $(2.72 \mathrm{~g}, 40.0 \mathrm{mmol}, 200.0$ equiv) and DMAP $(98 \mathrm{mg}$, $0.80 \mathrm{mmol}, 4.00$ equiv) as solids sequential, each in a single portion. After 5 minutes, to the resulting homogenous, pale yellow solution was added TBSCl ( $3.01 \mathrm{~g}, 20.0 \mathrm{mmol}, 100.0$ equiv) as a solution in $\mathrm{CH}_{2} \mathrm{Cl}_{2}(7.5 \mathrm{~mL})$ quickly dropwise over 5 minutes. After $17 \mathrm{~h}$, the consumption of starting material was complete as determined by TLC (19:1 EtOAc:Hexanes eluent). The reaction mixture was then filtered through a Celite ${ }^{\circledR}$ plug, washing with $\mathrm{CH}_{2} \mathrm{Cl}_{2}$ eluent. The combined organics were concentrated in vacuo and purified by silica gel column chromatography ( $15 \%$ acetone in hexanes eluent) to furnish diol allylic silyl ether $\mathbf{3 0}$ (23 mg, 26\% yield) as an amorphous white solid and unsaturated lactone 31 (66 mg, 74\% yield) as an amorphous white solid.

Allylic Silyl Ether 30: $\mathrm{R}_{f}=0.20$ (3:17 Acetone:Hexanes eluent); ${ }^{1} \mathrm{H}$ NMR $\left(\mathrm{CDCl}_{3}, 400 \mathrm{MHz}\right) \delta$ 4.78-4.67 (m, 3H), 4.26 (bt, $J=8.0 \mathrm{~Hz}, 1 \mathrm{H}), 3.35(\mathrm{dd}, J=6.1,4.5 \mathrm{~Hz}, 1 \mathrm{H}), 3.31(\mathrm{~d}, J=5.4$ $\mathrm{Hz}, 1 \mathrm{H}), 3.17$ (dd, $J=5.8,1.9 \mathrm{~Hz}, 1 \mathrm{H}), 2.97-2.78(\mathrm{~m}, 2 \mathrm{H})$, $2.78-2.67(\mathrm{~m}, 1 \mathrm{H}), 2.55(\mathrm{bs}, 1 \mathrm{H}), 2.42-2.24(\mathrm{~m}, 3 \mathrm{H}), 2.06(\mathrm{ddt}$,
$J=12.2,6.3,2.3 \mathrm{~Hz}, 1 \mathrm{H}), 1.79-1.69(\mathrm{~m}, 4 \mathrm{H}), 1.40$ (ddd, $J=$ $13.5,12.4,10.3 \mathrm{~Hz}, 1 \mathrm{H}), 1.34(\mathrm{~s}, 3 \mathrm{H}), 0.92(\mathrm{~s}, 9 \mathrm{H}), 0.13(\mathrm{~s}, 3 \mathrm{H})$ $0.11(\mathrm{~s}, 3 \mathrm{H}) ;{ }^{13} \mathrm{C}\left\{{ }^{1} \mathrm{H}\right\}$ NMR $\left(\mathrm{CDCl}_{3}, 101 \mathrm{MHz}\right) \delta 173.9,148.6$, 130.5, 126.5, 109.4, 79.7, 75.3, 75.0, 70.5, 55.8, 48.9, 45.8, 44.3, $38.7,38.5,37.4,28.6,26.6,26.2,20.9,18.4,-3.5,-4.6$; IR (Neat Film, NaCl) 3465, 2930, 2857, 1771, 1463, 1370, 1256, 1140, 1102, 1056, 988, 972, 883, 836, $774 \mathrm{~cm}^{-1}$; HRMS (FAB+) $\mathrm{m} / \mathrm{z}$ calc'd for $\mathrm{C}_{25} \mathrm{H}_{39} \mathrm{O}_{5} \mathrm{Si}[\mathrm{M}+\mathrm{H}]^{+}: 447.2567$, found 447.2552; $[\alpha]_{\mathrm{D}}^{25.0}+87.5^{\circ}\left(c 0.400, \mathrm{CHCl}_{3}\right)$.

Unsaturated Lactone 31: $\mathrm{R}_{f}=0.29$ (3:17 Acetone:Hexanes eluent); ${ }^{1} \mathrm{H}$ NMR $\left(\mathrm{CDCl}_{3}, 400 \mathrm{MHz}\right) \delta 4.80$ (ddd, $J=9.3,7.8$, $7.2 \mathrm{~Hz}, 1 \mathrm{H}), 4.75(\mathrm{dt}, J=1.8,0.9 \mathrm{~Hz}, 1 \mathrm{H}), 4.73(\mathrm{~s}, 1 \mathrm{H}), 4.16-$ 4.07 (m, 1H), 3.88 (ddd, $J=10.1,9.0,4.3 \mathrm{~Hz}, 1 \mathrm{H}), 3.81(\mathrm{dt}, J=$ 9.3, $2.5 \mathrm{~Hz}, 1 \mathrm{H}$ ), 3.37 (ddd, $J=5.4,2.0,0.7 \mathrm{~Hz}, 1 \mathrm{H}), 2.61-2.51$ (m, 2H), 2.41 (dtd, $J=9.3,4.7,2.4 \mathrm{~Hz}, 1 \mathrm{H}), 2.38-2.32(\mathrm{~m}, 1 \mathrm{H})$, $2.14(\mathrm{tt}, J=11.7,4.1 \mathrm{~Hz}, 1 \mathrm{H}), 2.08-1.97(\mathrm{~m}, 2 \mathrm{H}), 1.97-1.90(\mathrm{~m}$, $1 \mathrm{H}), 1.86$ (ddd, $J=13.7,11.1,2.5 \mathrm{~Hz}, 1 \mathrm{H}), 1.74(\mathrm{dd}, J=1.5,0.8$ $\mathrm{Hz}, 3 \mathrm{H}), 1.43(\mathrm{td}, J=12.5,10.2 \mathrm{~Hz}, 1 \mathrm{H}), 1.32(\mathrm{~d}, J=0.9 \mathrm{~Hz}$, $3 \mathrm{H}), 0.93(\mathrm{~s}, 9 \mathrm{H}), 0.13(\mathrm{~s}, 3 \mathrm{H}), 0.12(\mathrm{~s}, 3 \mathrm{H}) ;{ }^{13} \mathrm{C}\left\{{ }^{1} \mathrm{H}\right\}$ NMR $\left(\mathrm{CDCl}_{3}, 101 \mathrm{MHz}\right) \delta 169.7,158.8,148.2,116.1,109.6,74.5$, 73.5, 73.3, 70.9, 54.3, 51.6, 48.1, 41.5, 41.0, 40.4, 32.6, 26.0, 23.5, 22.7, 20.6, 18.2, -3.9, -4.7; IR (Neat Film, NaCl) 3494, 2929, 2857, 1742, 1645, 1455, 1360, 1259, 1176, 1121, 1078, 1053, 957, 918, 898, 837, $775 \mathrm{~cm}^{-1}$; HRMS (FAB+) $m / z$ calc'd for $\mathrm{C}_{25} \mathrm{H}_{39} \mathrm{O}_{5} \mathrm{Si}[\mathrm{M}+\mathrm{H}]^{+}: 447.2567$, found 447.2577 ; $[\alpha]_{\mathrm{D}}{ }^{25.0}$ $+56.1^{\circ}\left(c 0.600, \mathrm{CHCl}_{3}\right)$.

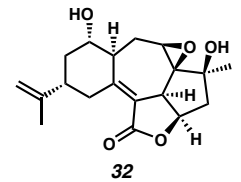

$\left(2 S, 2 \mathrm{a} S, 2 \mathrm{a}^{1} R, 3 \mathrm{a} R, 4 \mathrm{a} S, 5 S, 7 S, 10 \mathrm{a} R\right)-2,5-\mathrm{dihydroxy}-2-$ methyl-7-(prop-1-en-2-yl)-1,2a $1,3 \mathrm{a}, 4,4 \mathrm{a}, 5,6,7,8,10 \mathrm{a}-$ decahydrobenzo[6,7]oxireno[2',3':3a,4] azuleno[1,8-bc]furan9(2H)-one (32). To a stirred solution of silyl ether $31(4 \mathrm{mg}$, $0.009 \mathrm{mmol}, 1.00$ equiv $)$ in THF $(0.6 \mathrm{~mL})$ at $-78^{\circ} \mathrm{C}(i$-PrOH/dry ice bath) was added TBAF (11 mL, $1 \mathrm{M}$ in THF, 1.22 equiv) slowly dropwise. After $3 \mathrm{~h}$, the reaction was introduced to a $0{ }^{\circ} \mathrm{C}$ bath (ice/ $\mathrm{H}_{2} \mathrm{O}$ ). After a further $4 \mathrm{~h}$, the consumption of starting material was complete as determined by TLC (1:4 Acetone:Hexanes eluent). The reaction was removed from the cooling bath and immediately concentrated in vacuo. The crude dark brown oil was purified by silica gel column chromatography (EtOAc eluent) to provide epoxide 32 ( $3 \mathrm{mg},>99 \%$ yield) as an amorphous white solid: $\mathrm{R}_{f}=0.31$ (EtOAc eluent); ${ }^{1} \mathrm{H}$ NMR $\left(\mathrm{CDCl}_{3}, 400 \mathrm{MHz}\right) \delta 4.83(\mathrm{dt}, J=9.2,7.4 \mathrm{~Hz}, 1 \mathrm{H}), 4.77(\mathrm{dt}, J=$ $1.7,0.9 \mathrm{~Hz}, 1 \mathrm{H}), 4.75(\mathrm{q}, J=1.5 \mathrm{~Hz}, 1 \mathrm{H}), 3.96(\mathrm{dd}, J=14.0,4.7$ $\mathrm{Hz}, 1 \mathrm{H}), 3.93-3.86(\mathrm{~m}, 1 \mathrm{H}), 3.84(\mathrm{dt}, J=9.2,2.5 \mathrm{~Hz}, 1 \mathrm{H}), 3.43$ (dd, $J=4.8,2.2 \mathrm{~Hz}, 1 \mathrm{H}), 2.63-2.52(\mathrm{~m}, 2 \mathrm{H}), 2.42$ (dddd, $J=8.3$, 6.2, 4.3, 2.2 Hz, 1H), $2.32(\mathrm{bs}, 1 \mathrm{H}), 2.26-2.03(\mathrm{~m}, 4 \mathrm{H}), 1.93(\mathrm{dd}$, $J=13.3,7.3 \mathrm{~Hz}, 1 \mathrm{H}), 1.75(\mathrm{t}, J=1.1 \mathrm{~Hz}, 3 \mathrm{H}), 1.44(\mathrm{ddd}, J=$ 12.4, 11.7, $10.5 \mathrm{~Hz}, 1 \mathrm{H}), 1.33(\mathrm{t}, J=0.8 \mathrm{~Hz}, 3 \mathrm{H}) ;{ }^{13} \mathrm{C}\left\{{ }^{1} \mathrm{H}\right\}$ NMR $\left(\mathrm{CDCl}_{3}, 101 \mathrm{MHz}\right) \delta 169.6,158.0,148.0,116.9,109.8,74.6$, 73.5, 72.7, 70.4, 54.3, 50.8, 48.0, 41.6, 40.8, 40.1, 31.9, 23.5, 23.0, 20.8; IR (Neat Film, NaCl) 3418, 2964, 2925, 2855, 1732, 1644, 1446, 1372, 1260, 1177, 1103, 1048, 1029, 911, 802, 732 $\mathrm{cm}^{-1}$; HRMS (FAB+) $\mathrm{m} / \mathrm{z}$ calc'd for $\mathrm{C}_{19} \mathrm{H}_{25} \mathrm{O}_{5}[\mathrm{M}+\mathrm{H}]^{+}$: 333.1702 , found $333.1688 ;[\alpha]_{\mathrm{D}}{ }^{25.0}+14.3^{\circ}\left(c 0.150, \mathrm{CHCl}_{3}\right)$.

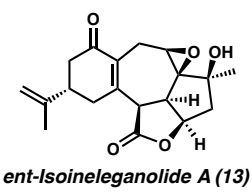


$\left(2 S, 2 \mathrm{a} S, 2 \mathrm{a}^{1} R, 3 \mathrm{a} R, 7 S, 8 \mathrm{~b} R, 10 \mathrm{a} R\right)-2$-hydroxy-2-methyl-7(prop-1-en-2-yl)-1,2a ${ }^{1}, 4,6,7,8,8 b, 10 a-$ octahydrobenzo[6,7] oxireno $[2 ', 3 ': 3 a, 4]$ azuleno $[1,8-b c]$ furan$5,9(2 H, 3 a H)$-dione (ent-Isoineleganolide A, 13). To a stirred solution of unsaturated lactone $32(3 \mathrm{mg}, 0.009 \mathrm{mmol}, 1.00$ equiv) in wet $\mathrm{CH}_{2} \mathrm{Cl}_{2}(1.3 \mathrm{~mL})$ at $0{ }^{\circ} \mathrm{C}$ (ice $/ \mathrm{H}_{2} \mathrm{O}$ bath) was added Dess-Martin periodinane (DMP, $8 \mathrm{mg}, 0.018 \mathrm{mmol}, 2.00$ equiv) as a solid in a single portion. After $2.5 \mathrm{~h}$, the consumption of starting material was complete as determined by TLC (EtOAc eluent). The reaction was quenched by the addition of saturated aqueous $\mathrm{Na}_{2} \mathrm{~S}_{2} \mathrm{O}_{3}(2 \mathrm{~mL})$ with vigorous stirring. After 15 minutes, the reaction was diluted with $\mathrm{CH}_{2} \mathrm{Cl}_{2}(5 \mathrm{~mL})$ and poured onto saturated aqueous $\mathrm{NaHCO}_{3}(2 \mathrm{~mL})$. The organics were separated and the aqueous was extracted with $\mathrm{CH}_{2} \mathrm{Cl}_{2}(3 \mathrm{x}$ $2 \mathrm{~mL}$ ). The combined organics were concentrated in vacuo. The crude golden solid was purified by silica gel column chromatography $(85 \%$ EtOAc in hexanes eluent) to provide entisoineleganolide A $(13,2 \mathrm{mg}, 66 \%$ yield $)$ as a crystalline white solid: characterization match those reported previously. ${ }^{8}$

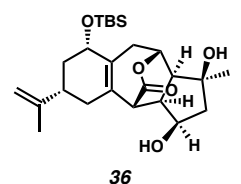

$(1 S, 3 R, 3 \mathrm{a} R, 4 R, 6 S, 8 S, 10 R, 10 \mathrm{a} S)-8-((t e r t-$ butyldimethylsilyl)oxy)-1,3-dihydroxy-1-methyl-6-(prop-1en-2-yl)-1,2,3,3a,4,5,6,7,8,9,10,10a-dodecahydro-10,4(epoxymethano)benzo[f]azulen-12-one (36).

Preparation of 0.50 M Solution of Titanocene Monochloride $\left(\mathrm{Cp}_{2} \mathrm{TiCl}\right)$

Into a thoroughly flame-dried Schlenk tube under an overpressure of argon was charged with zinc(0) dust $(647 \mathrm{mg}, 9.90$ mmol, 3.00 equiv) and titanocene dichloride $\left(\mathrm{Cp}_{2} \mathrm{TiCl}_{2}, 822 \mathrm{mg}\right.$, $3.30 \mathrm{mmol}, 1.00$ equiv). The flask was then evacuated and back filled with argon ( 3 x 5 minute cycles). To the reaction vessel was then added THF $(6.6 \mathrm{~mL})$ that had previously been sparged with argon for 60 minutes and stirring commenced. After $1.5 \mathrm{~h}$, the bright red reaction mixture had become dark green and stirring was halted. After 30 minutes, the supernatant was used as a $0.50 \mathrm{M}$ stock solution of $\mathrm{Cp}_{2} \mathrm{TiCl}$.

Epoxide Opening with $\mathrm{Cp}_{2} \mathrm{TiCl}$

A stirred solution of epoxide $30(8 \mathrm{mg}, 0.018 \mathrm{mmol}, 1.00$ equiv) in THF $(2.0 \mathrm{~mL})$ was sparged with argon for $1 \mathrm{~h}$, resulting in a reaction volume of $0.8 \mathrm{~mL}$. The homogeneous, off-white reaction mixture was then cooled to $-78{ }^{\circ} \mathrm{C}(i$-PrOH/dry ice bath) followed by the addition of $\mathrm{H}_{2} \mathrm{O}(27 \mu \mathrm{L}, 1.50 \mathrm{mmol}, 55.6$ equiv). After stirring for 5 minutes, $\mathrm{Cp}_{2} \mathrm{TiCl}(0.38 \mathrm{mmol}, 0.50 \mathrm{M}$ in THF, 14.1 equiv) was added dropwise over 3 minutes. After 2 $\mathrm{h}$, the reaction vessel was warmed to $0{ }^{\circ} \mathrm{C}$ (ice $/ \mathrm{H}_{2} \mathrm{O}$ bath). After an additional $2.5 \mathrm{~h}$, the Schlenk tube was removed from the cooling bath and allowed to warm to ambient temperature. After an additional $12.5 \mathrm{~h}$, the consumption of starting material was complete as determined by TLC (3:17 Acetone:Hexanes eluent). The reaction was quenched by the addition of saturated $\mathrm{NaH}_{2} \mathrm{PO}_{4}$ $(0.25 \mathrm{~mL})$ and brine $(0.25 \mathrm{~mL})$, sparged with compressed air for 5 minutes, and allowed to stir for an additional 15 minutes. The reaction mixture was then filtered through a Celite ${ }^{\circledR}$ plug, washing with $50 \%$ acetone in hexanes eluent. The combined organics were concentrated in vacuo and purified twice by silica gel column chromatography (first column: $45 \%$ EtOAc in $\mathrm{CH}_{2} \mathrm{Cl}_{2}$ eluent, second column: $40 \%$ EtOAc in $\mathrm{CH}_{2} \mathrm{Cl}_{2}$ eluent) to furnish diol 36 (2 mg, 25\% yield) as an amorphous white solid: $\mathrm{R}_{f}=$ 0.40 (1:1 EtOAc: $\mathrm{CH}_{2} \mathrm{Cl}_{2}$ eluent); ${ }^{1} \mathrm{H}$ NMR $\left(\mathrm{CDCl}_{3}, 400 \mathrm{MHz}\right) \delta$ $5.00(\mathrm{dd}, J=4.5,2.6 \mathrm{~Hz}, 1 \mathrm{H}), 4.74(\mathrm{p}, J=1.7 \mathrm{~Hz}, 1 \mathrm{H}), 4.71(\mathrm{dd}$,
$J=1.9,0.9 \mathrm{~Hz}, 1 \mathrm{H}), 4.33(\mathrm{tt}, J=4.9,2.1 \mathrm{~Hz}, 1 \mathrm{H}), 4.14(\mathrm{td}, J=$ $6.3,3.0 \mathrm{~Hz}, 1 \mathrm{H}), 3.55(\mathrm{~s}, 1 \mathrm{H}), 3.16(\mathrm{~d}, J=5.3 \mathrm{~Hz}, 1 \mathrm{H}), 3.06(\mathrm{~d}, J$ $=1.6 \mathrm{~Hz}, 1 \mathrm{H}), 2.98(\mathrm{ddd}, J=12.3,5.0,1.6 \mathrm{~Hz}, 1 \mathrm{H}), 2.84-2.71$ (m, 1H), 2.60-2.47 (m, 1H), 2.35-2.15 (m, 5H), 2.06-1.91 (m, 2H), $1.74-1.70(\mathrm{~m}, 3 \mathrm{H}), 1.67(\mathrm{dd}, J=14.0,3.7 \mathrm{~Hz}, 1 \mathrm{H}), 1.44$ (td, $J=13.3,12.8,10.2 \mathrm{~Hz}, 1 \mathrm{H}), 1.34$ (s, 3H), 0.90 (s, 9H), 0.09 $(\mathrm{s}, 3 \mathrm{H}), 0.08(\mathrm{~s}, 3 \mathrm{H}) ;{ }^{13} \mathrm{C}\left\{{ }^{1} \mathrm{H}\right\} \mathrm{NMR}\left(\mathrm{CDCl}_{3}, 101 \mathrm{MHz}\right) \delta 173.3$, 148.2, 132.7, 129.4, 109.7, 81.4, 76.0, 74.0, 71.6, 51.5, 49.6, $48.4,47.7,39.7,38.1,37.6,36.8,27.4,26.1,20.6,18.3,-4.0$, 4.7; IR (Neat Film, NaCl) 3365, 2927, 2855, 1733, 1454, 1386, 1259, 1081, 1060, 876, 836, $775 \mathrm{~cm}^{-1}$; HRMS (FAB+) $\mathrm{m} / \mathrm{z}$ calc'd for $\mathrm{C}_{25} \mathrm{H}_{41} \mathrm{O}_{5} \mathrm{Si}[\mathrm{M}+\mathrm{H}]^{+}:$449.2723, found 449.2735; $[\alpha]_{\mathrm{D}}^{25.0}+31.3^{\circ}\left(c 0.100, \mathrm{CHCl}_{3}\right)$.

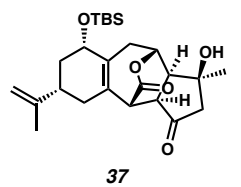

$(1 S, 3 \mathrm{a} R, 4 R, 6 S, 8 S, 10 R, 10 \mathrm{a} S)-8-((t e r t-$ butyldimethylsilyl)oxy)-1-hydroxy-1-methyl-6-(prop-1-en-2yl)-1,3a,4,5,6,7,8,9,10,10a-decahydro-10,4(epoxymethano)benzo[f]azulene-3,12(2H)-dione (37). To a stirred solution of diol 36 ( $10 \mathrm{mg}, 0.022 \mathrm{mmol}, 1.00$ equiv) in wet $\mathrm{CH}_{2} \mathrm{Cl}_{2}(2.0 \mathrm{~mL})$ at $0{ }^{\circ} \mathrm{C}\left(\mathrm{ice} / \mathrm{H}_{2} \mathrm{O}\right.$ bath $)$ was added DessMartin periodinane (DMP, $30 \mathrm{mg}, 0.071 \mathrm{mmol}, 3.23$ equiv) was a solid in a single portion. After $3 \mathrm{~h}$, the white suspension was removed from the cooling bath and allowed to warm to ambient temperature (ca. $23{ }^{\circ} \mathrm{C}$ ). After an additional $10 \mathrm{~h}$, the consumption of starting material was complete as determined by TLC (1:1 EtOAc: $\mathrm{CH}_{2} \mathrm{Cl}_{2}$ eluent). The reaction was quenched by the addition of saturated aqueous $\mathrm{Na}_{2} \mathrm{~S}_{2} \mathrm{O}_{3}(3 \mathrm{~mL})$ with vigorous stirring. After 15 minutes, the reaction was diluted with $\mathrm{CH}_{2} \mathrm{Cl}_{2}(10$ $\mathrm{mL})$ and poured onto saturated aqueous $\mathrm{NaHCO}_{3}(3 \mathrm{~mL})$. The organics were separated and the aqueous was extracted with $\mathrm{CH}_{2} \mathrm{Cl}_{2}(4 \times 2 \mathrm{~mL})$. The combined organics were concentrated in vacuo. The crude golden solid was purified by silica gel column chromatography ( $15 \%$ EtOAc in hexanes eluent) to provide ketone 37 (6 mg, $60 \%$ yield) as an amorphous white solid: $\mathrm{R}_{f}=$ 0.27 (3:17 EtOAc: $\mathrm{CH}_{2} \mathrm{Cl}_{2}$ eluent); ${ }^{1} \mathrm{H} \mathrm{NMR}\left(\mathrm{CDCl}_{3}, 400 \mathrm{MHz}\right) \delta$ 5.25 (ddd, $J=5.0,2.3,0.8 \mathrm{~Hz}, 1 \mathrm{H}), 4.75(\mathrm{p}, J=1.5 \mathrm{~Hz}, 1 \mathrm{H})$, $4.72(\mathrm{dd}, J=1.7,0.9 \mathrm{~Hz}, 1 \mathrm{H}), 4.19-4.11(\mathrm{~m}, 1 \mathrm{H}), 3.26(\mathrm{~d}, J=$ $2.0 \mathrm{~Hz}, 1 \mathrm{H}), 3.22$ (ddt, $J=10.8,2.0,0.9 \mathrm{~Hz}, 1 \mathrm{H}), 2.86$ (dd, $J=$ $18.5,2.6 \mathrm{~Hz}, 1 \mathrm{H}), 2.69-2.38(\mathrm{~m}, 4 \mathrm{H}), 2.33-2.16(\mathrm{~m}, 3 \mathrm{H}), 2.04$ $1.95(\mathrm{~m}, 1 \mathrm{H}), 1.72(\mathrm{dd}, J=1.5,0.8 \mathrm{~Hz}, 3 \mathrm{H}), 1.48(\mathrm{~s}, 3 \mathrm{H}), 1.47-$ $1.38(\mathrm{~m}, 1 \mathrm{H}), 0.92(\mathrm{~s}, 9 \mathrm{H}), 0.10(\mathrm{~s}, 3 \mathrm{H}), 0.10(\mathrm{~s}, 3 \mathrm{H}) ;{ }^{13} \mathrm{C}\left\{{ }^{1} \mathrm{H}\right\}$ NMR $\left(\mathrm{CDCl}_{3}, 101 \mathrm{MHz}\right) \delta 212.0,169.9,147.8,133.3,129.3$, 109.9, 75.1, 74.0, 71.6, 53.3, 52.9, 47.8, 47.4, 39.6, 37.5, 37.5, $36.7,29.1,26.1,20.5,18.3,-3.9,-4.7$; IR (Neat Film, NaCl) 3447, 2927, 2856, 1750, 1378, 1257, 1185, 1063, 872, 836, 777 $\mathrm{cm}^{-1}$; HRMS (FAB+) $\mathrm{m} / \mathrm{z}$ calc'd for $\mathrm{C}_{25} \mathrm{H}_{39} \mathrm{O}_{5} \mathrm{Si}[\mathrm{M}+\mathrm{H}]^{+}$: 447.2567, found 447.2551; $[\alpha]_{\mathrm{D}}^{25.0}+35.4^{\circ}\left(c 0.300, \mathrm{CHCl}_{3}\right)$.

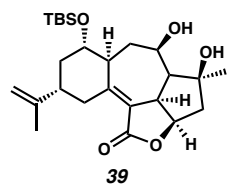

$\left(2 \mathrm{a} R, 2 \mathrm{a}^{1} R, 4 S, 5 R, 6 \mathrm{a} S, 7 S, 9 S\right)-7-((t e r t-$ butyldimethylsilyl)oxy)-4,5-dihydroxy-4-methyl-9-(prop-1en-2-yl)-2a,2a ${ }^{1}, 3,4,4 a, 5,6,6 a, 7,8,9,10$-dodecahydro- $1 H$ benzo[6,7]azuleno[1,8-bc]furan-1-one (39).

Preparation of $0.50 \mathrm{M}$ Solution of Titanocene Monochloride $\left(\mathrm{Cp}{ }_{2} \mathrm{TiCl}\right)$ 
Into a thoroughly flame-dried Schlenk tube under an overpressure of argon was charged with zinc(0) dust (647 mg, 9.90 mmol, 3.00 equiv) and titanocene dichloride $\left(\mathrm{Cp}_{2} \mathrm{TiCl}_{2}, 822 \mathrm{mg}\right.$, $3.30 \mathrm{mmol}, 1.00$ equiv). The flask was then evacuated and back filled with argon $(3 \times 5$ minute cycles). To the reaction vessel was then added THF $(6.6 \mathrm{~mL})$ that had previously been sparged with argon for 60 minutes and stirring commenced. After $1.5 \mathrm{~h}$, the bright red reaction mixture had become dark green and stirring was halted. After 30 minutes, the supernatant was used as a $0.50 \mathrm{M}$ stock solution of $\mathrm{Cp}_{2} \mathrm{TiCl}$.

Epoxide Opening with $\mathrm{Cp}_{2} \mathrm{TiCl}$

A stirred solution of epoxide $31(12 \mathrm{mg}, 0.027 \mathrm{mmol}, 1.00$ equiv) in THF $(2.0 \mathrm{~mL})$ was sparged with argon for $1 \mathrm{~h}$, resulting in a reaction volume of $0.8 \mathrm{~mL}$. The homogeneous, off-white reaction mixture was then cooled to $-78{ }^{\circ} \mathrm{C}(i$ - $\mathrm{PrOH} / \mathrm{dry}$ ice bath) followed by the addition of $\mathrm{H}_{2} \mathrm{O}(27 \mu \mathrm{L}, 1.50 \mathrm{mmol}, 55.6$ equiv). After stirring for 5 minutes, $\mathrm{Cp}_{2} \mathrm{TiCl}(0.38 \mathrm{mmol}, 0.50 \mathrm{M}$ in THF, 14.1 equiv) was added dropwise over 3 minutes. After 2 $\mathrm{h}$, the reaction vessel was warmed to $0{ }^{\circ} \mathrm{C}$ (ice $/ \mathrm{H}_{2} \mathrm{O}$ bath). After an additional $2.5 \mathrm{~h}$, the Schlenk tube was removed from the cooling bath and allowed to warm to ambient temperature. After an additional $12.5 \mathrm{~h}$, the consumption of starting material was complete as determined by TLC (3:17 Acetone:Hexanes eluent). The reaction was quenched by the addition of saturated $\mathrm{NaH}_{2} \mathrm{PO}_{4}$ $(0.25 \mathrm{~mL})$ and brine $(0.25 \mathrm{~mL})$, sparged with compressed air for 5 minutes, and allowed to stir for an additional 15 minutes. The reaction mixture was then filtered through a Celite ${ }^{\mathbb{B}}$ plug, washing with $50 \%$ acetone in hexanes eluent. The combined organics were concentrated in vacuo and purified twice by silica gel column chromatography ( $25 \%$ EtOAc in $\mathrm{CH}_{2} \mathrm{Cl}_{2}$ eluent) to furnish diol 39 (5 mg, 42\% yield) as an amorphous white solid: $\mathrm{R}_{f}=$ 0.19 (1:4 EtOAc: $\mathrm{CH}_{2} \mathrm{Cl}_{2}$ eluent); ${ }^{1} \mathrm{H}$ NMR $\left(\mathrm{CDCl}_{3}, 400 \mathrm{MHz}\right) \delta$ 4.89 (ddd, $J=8.3,6.3,2.2 \mathrm{~Hz}, 1 \mathrm{H}), 4.77-4.73$ (m, 1H), 4.69 (q, $J=1.5 \mathrm{~Hz}, 1 \mathrm{H}), 4.53(\mathrm{q}, J=4.2 \mathrm{~Hz}, 1 \mathrm{H}), 3.89$ (ddd, $J=9.4,7.6$, $4.2 \mathrm{~Hz}, 1 \mathrm{H}), 3.86-3.80(\mathrm{~m}, 1 \mathrm{H}), 3.79-3.69(\mathrm{~m}, 1 \mathrm{H}), 3.44-3.34$ (m, 1H), $2.76(\mathrm{ddt}, J=19.1,10.6,5.3 \mathrm{~Hz}, 1 \mathrm{H}), 2.73-2.68(\mathrm{~m}$, $1 \mathrm{H}), 2.60$ (dt, $J=8.7,7.0 \mathrm{~Hz}, 1 \mathrm{H}), 2.42$ (ddt, $J=14.7,11.9,4.4$ $\mathrm{Hz}, 1 \mathrm{H}), 2.20(\mathrm{dd}, J=14.6,2.1 \mathrm{~Hz}, 1 \mathrm{H}), 2.17-1.92(\mathrm{~m}, 6 \mathrm{H})$, $1.71(\mathrm{dd}, J=1.4,0.7 \mathrm{~Hz}, 3 \mathrm{H}), 1.43$ (s, 3H), 1.37 (ddd, $J=13.2$, $11.2,9.2 \mathrm{~Hz}, 1 \mathrm{H}), 0.90(\mathrm{~s}, 9 \mathrm{H}), 0.09(\operatorname{app~d}, J=0.9 \mathrm{~Hz}, 6 \mathrm{H})$; ${ }^{13} \mathrm{C}\left\{{ }^{1} \mathrm{H}\right\}$ NMR $\left(\mathrm{CDCl}_{3}, 101 \mathrm{MHz}\right) \delta 169.8,158.2,148.9,122.7$, 109.7, 81.7, 78.6, 74.6, 68.3, 52.8, 48.4, 47.4, 44.3, 38.8, 37.7, $34.2,29.6,26.9,26.0,20.1,18.1,-3.9,-4.5$; IR (Neat Film, $\mathrm{NaCl}) 3359,2928,2856,1727,1661,1463,1360,1311,1257$, 1230, 1110, 1073, 1034, 887, 836, $775 \mathrm{~cm}^{-1}$; HRMS (FAB+) $\mathrm{m} / \mathrm{z}$ calc'd for $\mathrm{C}_{25} \mathrm{H}_{41} \mathrm{O}_{5} \mathrm{Si}[\mathrm{M}+\mathrm{H}]^{+}$: 449.2723, found 449.2721; $[\alpha]_{\mathrm{D}}^{25.0}+46.4^{\circ}\left(c 0.250, \mathrm{CHCl}_{3}\right)$.

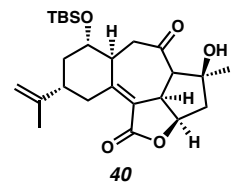

$\left(2 \mathrm{a} R, 2 \mathrm{a}^{1} R, 4 S, 6 \mathrm{a} S, 7 S, 9 S\right)-7-(($ tert-butyldimethylsilyl)oxy)-4hydroxy-4-methyl-9-(prop-1-en-2-yl)-2a ${ }^{1}, 3,4,4 a, 6,6 a, 7,8,9,10-$ decahydro-1 $H$-benzo[6,7]azuleno[1,8-bc]furan-1,5(2aH)-

dione (40). To a stirred solution of diol $39(49 \mathrm{mg}, 0.11 \mathrm{mmol}$, 1.00 equiv) in wet $\mathrm{CH}_{2} \mathrm{Cl}_{2}(2.2 \mathrm{~mL})$ at $0{ }^{\circ} \mathrm{C}$ (ice/ $\mathrm{H}_{2} \mathrm{O}$ bath) was added Dess-Martin periodinane (DMP, $140 \mathrm{mg}, 0.33 \mathrm{mmol}, 3.00$ equiv) was a solid in a single portion. After 30 minutes, the white suspension was removed from the cooling bath and allowed to warm to ambient temperature (ca. $23^{\circ} \mathrm{C}$ ). After $2 \mathrm{~h}$, additional DMP (140 mg, $0.33 \mathrm{mmol}, 3.00$ equiv) was added in a single portion. After an additional $10.5 \mathrm{~h}$, the consumption of starting material was complete as determined by TLC (1:4 EtOAc: $\mathrm{CH}_{2} \mathrm{Cl}_{2}$ eluent). The reaction was quenched by the addi- tion of saturated aqueous $\mathrm{Na}_{2} \mathrm{~S}_{2} \mathrm{O}_{3}(4 \mathrm{~mL})$ with vigorous stirring. After 15 minutes, the reaction was diluted with $\mathrm{CH}_{2} \mathrm{Cl}_{2}(10 \mathrm{~mL})$ and poured onto saturated aqueous $\mathrm{NaHCO}_{3}(4 \mathrm{~mL})$. The organics were separated and the aqueous was extracted with $\mathrm{CH}_{2} \mathrm{Cl}_{2}(4$ x $2 \mathrm{~mL}$ ). The combined organics were concentrated in vacuo. The crude golden brown solid was purified by silica gel column chromatography ( $8 \%$ EtOAc in hexanes eluent) to provide ketone $40\left(10 \mathrm{mg}, 23 \%\right.$ yield) as an amorphous white solid: $\mathrm{R}_{f}=$ 0.27 (1:19 EtOAc: $\mathrm{CH}_{2} \mathrm{Cl}_{2}$ eluent); ${ }^{1} \mathrm{H}$ NMR $\left(\mathrm{CDCl}_{3}, 400 \mathrm{MHz}\right) \delta$ 4.94 (ddd, $J=8.2,7.4,0.9 \mathrm{~Hz}, 1 \mathrm{H}), 4.76-4.70(\mathrm{~m}, 2 \mathrm{H}), 4.37$ (ddd, $J=14.4,3.9,2.0 \mathrm{~Hz}, 1 \mathrm{H}), 4.17$ (tt, $J=8.5,2.8 \mathrm{~Hz}, 1 \mathrm{H}$ ), 3.73 (ddd, $J=10.6,9.2,4.5 \mathrm{~Hz}, 1 \mathrm{H}), 3.13$ (dd, $J=12.2,6.8 \mathrm{~Hz}$, $1 \mathrm{H}), 3.08(\mathrm{~d}, J=8.9 \mathrm{~Hz}, 1 \mathrm{H}), 2.82(\mathrm{dd}, J=12.2,3.8 \mathrm{~Hz}, 1 \mathrm{H})$, 2.68 (ddt, $J=9.9,6.6,3.2 \mathrm{~Hz}, 1 \mathrm{H}), 2.58(\mathrm{~d}, J=2.4 \mathrm{~Hz}, 1 \mathrm{H})$, $2.28(\mathrm{~d}, J=15.2 \mathrm{~Hz}, 1 \mathrm{H}), 2.11-1.95(\mathrm{~m}, 2 \mathrm{H}), 1.87$ (ddd, $J=$ $15.2,7.4,2.5 \mathrm{~Hz}, 1 \mathrm{H}), 1.81-1.70(\mathrm{~m}, 4 \mathrm{H}), 1.51-1.40(\mathrm{~m}, 4 \mathrm{H})$, $0.91(\mathrm{~s}, 9 \mathrm{H}), 0.18(\mathrm{~s}, 3 \mathrm{H}), 0.14(\mathrm{~s}, 3 \mathrm{H}) ;{ }^{13} \mathrm{C}\left\{{ }^{1} \mathrm{H}\right\} \mathrm{NMR}\left(\mathrm{CDCl}_{3}\right.$, $101 \mathrm{MHz}) \delta 209.3,169.7,153.6,148.1,123.9,109.6,78.5,73.1$, $67.6,50.5,47.3,43.8,40.5,40.4,40.0,32.3,29.9,27.2,26.1$, 20.8, 18.2,-3.9, -4.5; IR (Neat Film, NaCl) 3542, 2929, 2857, 1733, 1634, 1456, 1362, 1256, 1182, 1147, 1090, 1033, 891, 838, $777 \mathrm{~cm}^{-1}$; HRMS (FAB+) $\mathrm{m} / z$ calc'd for $\mathrm{C}_{25} \mathrm{H}_{39} \mathrm{O}_{5} \mathrm{Si}$ $[\mathrm{M}+\mathrm{H}]^{+}: 447.2567$, found $447.2553 ;[\alpha]_{\mathrm{D}}^{25.0}+94.3^{\circ}$ (c 0.750, $\left.\mathrm{CHCl}_{3}\right)$.

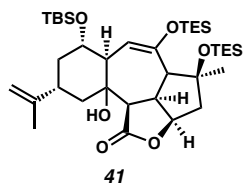

$\left(2 \mathrm{a} R, 2 \mathrm{a}^{1} R, 4 S, 6 \mathrm{a} R, 7 S, 9 R, 10 \mathrm{~b} R\right)-7-((t e r t-$ butyldimethylsilyl)oxy)-10a-hydroxy-4-methyl-9-(prop-1-en2-yl)-4,5-bis((triethylsilyl)oxy)-

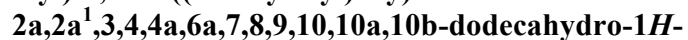
benzo[6,7]azuleno[1,8-bc]furan-1-one (41). To a stirred solution of ketone 40 (13 mg, $0.029 \mathrm{mmol}, 1.00$ equiv) in $\mathrm{CH}_{2} \mathrm{Cl}_{2}$ $(1.0 \mathrm{~mL})$ at $0{ }^{\circ} \mathrm{C}\left(\right.$ ice $/ \mathrm{H}_{2} \mathrm{O}$ bath) was added $\mathrm{Et}_{3} \mathrm{~N}(0.20 \mathrm{~mL}, 1.45$ mmol, 50.0 equiv) dropwise. After 5 minutes, TESOTf $(66 \mathrm{~mL}$, 0.29 mmol, 10.0 equiv) was added slowly dropwise. After an additional 20 minutes, the consumption of starting material was complete as determined by TLC (1:19 EtOAc: $\mathrm{CH}_{2} \mathrm{Cl}_{2}$ eluent). The reaction was quenched by the addition of saturated aqueous $\mathrm{NaHCO}_{3}(50 \mathrm{~mL})$ and immediately removed from the cooling bath and allowed to warm to ambient temperature (ca. $23{ }^{\circ} \mathrm{C}$ ). The reaction mixture was then filtered through a silica gel plug, eluting with $10 \%$ EtOAc in hexanes. The combined organics were concentrated in vacuo. The crude tan solid was purified by silica gel column chromatography (5\% EtOAc in hexanes eluent) to provide enol ether 41 (11 $\mathrm{mg}, 55 \%$ yield) as an amorphous white solid: $\mathrm{R}_{f}=0.50$ (1:9 EtOAc:Hexanes eluent); ${ }^{1} \mathrm{H}$ NMR $\left(\mathrm{CDCl}_{3}, 400 \mathrm{MHz}\right) \delta 5.48(\mathrm{t}, J=2.5 \mathrm{~Hz}, 1 \mathrm{H}), 4.91(\mathrm{td}, J=8.3$, $6.0 \mathrm{~Hz}, 1 \mathrm{H}), 4.72$ (q, $J=1.2 \mathrm{~Hz}, 2 \mathrm{H}), 3.61$ (ddd, $J=11.6,8.3$, $3.4 \mathrm{~Hz}, 1 \mathrm{H}), 3.13-3.04(\mathrm{~m}, 1 \mathrm{H}), 2.68-2.53(\mathrm{~m}, 3 \mathrm{H}), 2.45-2.33$ $(\mathrm{m}, 2 \mathrm{H}), 2.26(\mathrm{ddd}, J=13.1,8.1,1.3 \mathrm{~Hz}, 1 \mathrm{H}), 1.97-1.87(\mathrm{~m}$, $1 \mathrm{H}), 1.66(\mathrm{t}, J=1.1 \mathrm{~Hz}, 3 \mathrm{H}), 1.60-1.46(\mathrm{~m}, 4 \mathrm{H}), 1.15(\mathrm{~d}, J=1.2$ $\mathrm{Hz}, 3 \mathrm{H}), 0.95$ (td, $J=8.0,5.4 \mathrm{~Hz}, 18 \mathrm{H}), 0.92(\mathrm{~s}, 9 \mathrm{H}), 0.68-0.57$ $(\mathrm{m}, 12 \mathrm{H}), 0.10(\mathrm{~s}, 6 \mathrm{H}) ;{ }^{13} \mathrm{C}\left\{{ }^{1} \mathrm{H}\right\}$ NMR $\left(\mathrm{CDCl}_{3}, 101 \mathrm{MHz}\right) \delta$ 174.7, 147.8, 138.3, 124.2, 110.7, 88.6, 82.3, 80.2, 74.9, 59.6, $56.4,48.1,47.4,47.0,45.0,44.2,38.1,29.9,25.9,20.2,18.2$, 7.4, 7.2, 6.9, 6.8, -4.0, -4.5; IR (Neat Film, NaCl) 2954, 2876, $1767,1463,1373,1353,1332,1251,1157,1116,1090,1028$, 871, 836, 775, $743 \mathrm{~cm}^{-1}$; HRMS (ES+) $\mathrm{m} / z$ calc'd for $\mathrm{C}_{37} \mathrm{H}_{69} \mathrm{O}_{6}$ $\mathrm{Si}_{3}[\mathrm{M}+\mathrm{H}]^{+}: 693.4402$, found $693.4422 ;[\alpha]_{\mathrm{D}}{ }^{25.0}+34.9^{\circ}(c 0.250$, $\mathrm{CHCl}_{3}$ ). 


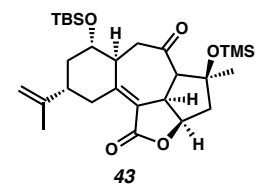

(2a $\left.R, 2 \mathrm{a}^{1} R, 4 S, 6 \mathrm{a} S, 7 S, 9 S\right)-7-(($ tert-butyldimethylsilyl)oxy)-4methyl-9-(prop-1-en-2-yl)-4-((trimethylsilyl)oxy)-

$2 a^{1}, 3,4,4 a, 6,6 a, 7,8,9,10-d e c a h y d r o-1 H$-benzo $[6,7]$ azuleno[1,8bc]furan-1,5(2aH)-dione (43). To a stirred solution of ketone 40 ( $4 \mathrm{mg}, 0.009 \mathrm{mmol}, 1.00$ equiv) in $\mathrm{CH}_{2} \mathrm{Cl}_{2}(1.0 \mathrm{~mL})$ at $0{ }^{\circ} \mathrm{C}$ (ice/ $\mathrm{H}_{2} \mathrm{O}$ bath) was added $\mathrm{Et}_{3} \mathrm{~N}(126 \mathrm{ml}, 0.90 \mathrm{mmol}, 100.0$ equiv) dropwise. After 5 minutes, TMSOTf $(20 \mathrm{~mL}, 0.11 \mathrm{mmol}$, 12.2 equiv) was added slowly dropwise. After an additional 5 minutes, the consumption of starting material was complete as determined by TLC (1:19 EtOAc: $\mathrm{CH}_{2} \mathrm{Cl}_{2}$ eluent). The reaction was quenched by the addition of saturated aqueous $\mathrm{NaHCO}_{3}(1.5$ $\mathrm{mL}$ ) and immediately removed from the cooling bath and allowed to warm to ambient temperature (ca. $23{ }^{\circ} \mathrm{C}$ ). The reaction was diluted with $\mathrm{Et}_{2} \mathrm{O}(2 \mathrm{~mL})$ and poured onto $\mathrm{H}_{2} \mathrm{O}(3 \mathrm{~mL})$. The organics were separated and the aqueous was extracted with $\mathrm{Et}_{2} \mathrm{O}(3 \times 2 \mathrm{~mL})$. The combined organics were dried over $\mathrm{MgSO}_{4}$, filtered, and concentrated in vacuo. The crude white solid was purified by silica gel column chromatography $(18 \%$ EtOAc in hexanes eluent) to provide bis-silyl ether 43 (4 mg, $>99 \%$ yield) as an amorphous white solid: $R_{f}=0.28$ (1:4 EtOAc:Hexanes eluent); ${ }^{1} \mathrm{H}$ NMR $\left(\mathrm{C}_{6} \mathrm{D}_{6}, 400 \mathrm{MHz}\right) \delta$ 5.05-4.97 $(\mathrm{m}, 1 \mathrm{H}), 4.94(\mathrm{dt}, J=1.9,0.9 \mathrm{~Hz}, 1 \mathrm{H}), 4.84(\mathrm{p}, J=1.5 \mathrm{~Hz}, 1 \mathrm{H})$, $4.18(\mathrm{t}, J=7.8 \mathrm{~Hz}, 1 \mathrm{H}), 3.73$ (ddd, $J=10.7,9.6,4.4 \mathrm{~Hz}, 1 \mathrm{H})$, $3.13(\mathrm{tt}, J=8.1,2.9 \mathrm{~Hz}, 1 \mathrm{H}), 2.86(\mathrm{dd}, J=11.5,3.6 \mathrm{~Hz}, 1 \mathrm{H})$, $2.62(\mathrm{dd}, J=11.5,5.4 \mathrm{~Hz}, 1 \mathrm{H}), 2.41$ (ddt, $J=9.0,6.0,3.3 \mathrm{~Hz}$, $1 \mathrm{H}), 2.28-2.16(\mathrm{~m}, 2 \mathrm{H}), 1.90(\mathrm{~d}, J=14.9 \mathrm{~Hz}, 1 \mathrm{H}), 1.83(\mathrm{dd}, J=$ $1.5,0.8 \mathrm{~Hz}, 3 \mathrm{H}), 1.70(\mathrm{~d}, J=8.0 \mathrm{~Hz}, 1 \mathrm{H}), 1.68-1.49(\mathrm{~m}, 2 \mathrm{H})$, $1.39(\mathrm{~s}, 3 \mathrm{H}), 1.08(\mathrm{~s}, 9 \mathrm{H}), 1.03(\mathrm{dd}, J=14.9,7.6 \mathrm{~Hz}, 1 \mathrm{H}), 0.40$ $(\mathrm{s}, 3 \mathrm{H}), 0.20(\mathrm{~s}, 3 \mathrm{H}), 0.15(\mathrm{~s}, 9 \mathrm{H}) ;{ }^{13} \mathrm{C}\left\{{ }^{1} \mathrm{H}\right\}$ NMR $\left(\mathrm{C}_{6} \mathrm{D}_{6}, 101\right.$ $\mathrm{MHz}) \delta 204.9,169.9,150.1,148.5,124.5,109.5,81.3,76.5$, $73.3,68.3,50.9,48.5,43.6,41.2,41.2,40.3,33.3,26.4,26.0$, 21.1, 18.5, 2.4, -4.1, -4.3; IR (Neat Film, NaCl) 2928, 2856, 1738, 1716, 1635, 1455, 1362, 1251, 1184, 1149, 1093, 1017, $886,837,778 \mathrm{~cm}^{-1}$; HRMS (FAB+) $m / z$ calc'd for $\mathrm{C}_{28} \mathrm{H}_{47} \mathrm{O}_{5} \mathrm{Si}_{2}$ $[\mathrm{M}+\mathrm{H}]^{+}: 519.2962$, found $519.2954 ;[\alpha]_{\mathrm{D}}{ }^{25.0}+61.8^{\circ}(c) 0.200$, benzene).

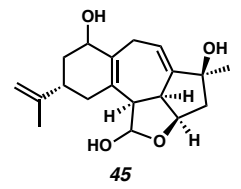

(2a $\left.R, 2 \mathrm{a}^{1} S, 4 S, 9 S, 10 \mathrm{~b} R\right)-4-m e t h y l-9-($ prop-1-en-2-yl)2a,2a ${ }^{1}, 3,4,6,7,8,9,10,10 b-d e c a h y d r o-1 H$ benzo[6,7]azuleno[1,8-bc] furan-1,4,7-triol (45). ${ }^{38}$ To a stirred solution of diene $\mathbf{5}\left(5 \mathrm{mg}, 0.016 \mathrm{mmol}, 1.00\right.$ equiv) in $\mathrm{CH}_{2} \mathrm{Cl}_{2}$ $(0.70 \mathrm{~mL})$ at $-78{ }^{\circ} \mathrm{C}(i$-PrOH/dry ice bath $)$ was added DIBAL (48 mL, $1.00 \mathrm{M}$ in $\mathrm{CH}_{2} \mathrm{Cl}_{2}, 3.00$ equiv) slowly dropwise. After $5.5 \mathrm{~h}$, the consumption of starting material was complete as determined by TLC (1:4 EtOAc: $\mathrm{CH}_{2} \mathrm{Cl}_{2}$ eluent). The reaction was quenched by the addition of saturated aqueous $\mathrm{NH}_{4} \mathrm{Cl}(0.5 \mathrm{~mL})$ and saturated aqueous Rochelle salt $(0.5 \mathrm{~mL})$ and immediately removed from the cooling bath and allowed to warm to ambient temperature (ca. $23{ }^{\circ} \mathrm{C}$ ). After stirring for $1 \mathrm{~h}$, the reaction was diluted with $\mathrm{CH}_{2} \mathrm{Cl}_{2}(2.0 \mathrm{~mL})$ and poured onto $\mathrm{H}_{2} \mathrm{O}(3.0 \mathrm{~mL})$. The organics were separated and the aqueous was extracted with $\mathrm{CH}_{2} \mathrm{Cl}_{2}(4 \times 1.5 \mathrm{~mL})$. The combined organics were dried over $\mathrm{MgSO}_{4}$, filtered, and concentrated in vacuo. The crude off-white solid was purified by silica gel column chromatography $(50 \%$ EtOAc in hexanes eluent) to provide lactol $45(11 \mathrm{mg}, 55 \%$ yield) as an amorphous white solid: $\mathrm{R}_{f}=0.21$ (1:1 EtOAc: $\mathrm{CH}_{2} \mathrm{Cl}_{2}$ eluent); ${ }^{1} \mathrm{H} \mathrm{NMR}\left(\mathrm{CDCl}_{3}, 400 \mathrm{MHz}\right) \delta 6.19$ (ddd, $J=8.6,4.5,3.0 \mathrm{~Hz}, 1 \mathrm{H}), 5.55(\mathrm{~d}, J=5.2 \mathrm{~Hz}, 1 \mathrm{H}), 4.77$ (p, $J=$ $1.7 \mathrm{~Hz}, 1 \mathrm{H}), 4.73(\mathrm{dt}, J=2.0,1.0 \mathrm{~Hz}, 1 \mathrm{H}), 4.61(\mathrm{t}, J=4.7 \mathrm{~Hz}$, $1 \mathrm{H}), 4.28-4.17(\mathrm{~m}, 1 \mathrm{H}), 3.66-3.58(\mathrm{~m}, 1 \mathrm{H}), 3.06(\mathrm{~d}, J=17.5$ $\mathrm{Hz}, 1 \mathrm{H}), 3.01-2.93(\mathrm{~m}, 1 \mathrm{H}), 2.83(\mathrm{dd}, J=17.2,8.6 \mathrm{~Hz}, 1 \mathrm{H})$, $2.40(\mathrm{~d}, J=15.1 \mathrm{~Hz}, 1 \mathrm{H}), 2.37-2.20(\mathrm{~m}, 2 \mathrm{H}), 2.16$ (dddd, $J=$ $12.6,6.1,2.9,1.8 \mathrm{~Hz}, 1 \mathrm{H}), 2.02-1.92(\mathrm{~m}, 2 \mathrm{H}), 1.76(\mathrm{t}, J=1.1$ $\mathrm{Hz}, 3 \mathrm{H}), 1.65-1.59(\mathrm{~m}, 1 \mathrm{H}), 1.41(\mathrm{~s}, 3 \mathrm{H}) ;{ }^{13} \mathrm{C}\left\{{ }^{1} \mathrm{H}\right\} \quad \mathrm{NMR}$ $\left(\mathrm{CDCl}_{3}, 101 \mathrm{MHz}\right) \delta 151.6,149.0,134.05,129.7,126.9,109.8$, 100.7, 85.1, 79.0, 72.9, 52.1, 48.8, 47.7, 38.8, 37.9, 36.2, 27.9, 27.3, 21.0; IR (Neat Film, NaCl) 3316, 2923, 1658, 1442, 1373, 1260, 1107, 1023, 925, 888, 806, $754 \mathrm{~cm}^{-1}$; HRMS (ES+) $\mathrm{m} / z$ calc'd for $\mathrm{C}_{19} \mathrm{H}_{26} \mathrm{O}_{4}[\mathrm{M} \bullet]^{+}: 318.1831$, found $318.1780 ;[\alpha]_{\mathrm{D}}{ }^{25.0}$ $+27.1^{\circ}\left(c 0.200, \mathrm{CHCl}_{3}\right)$.

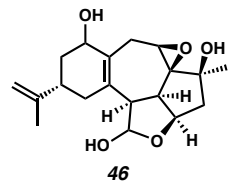

$\left(2 S, 2 \mathrm{a} S, 2 \mathrm{a}^{1} R, 3 \mathrm{a} R, 7 S, 8 \mathrm{~b} R, 10 \mathrm{a} R\right)-2-m e t h y l-7-(p r o p-1-e n-2-$ yl)-1,2,2a ${ }^{1}, 3 a, 4,5,6,7,8,8 b, 9,10 a-$ dodecahydrobenzo[6,7]oxireno[2',3':3a,4] azuleno[1,8bc|furan-2,5,9-triol (46). ${ }^{39}$ To a stirred solution of entisoineleganolide A $(\mathbf{1 3}, 5 \mathrm{mg}, 0.015 \mathrm{mmol}, 1.00$ equiv) in toluene $(0.70 \mathrm{~mL})$ at $-78{ }^{\circ} \mathrm{C}(i$-PrOH$/$ dry ice bath $)$ was added DIBAL (45 mL, 1.00 M in toluene, 3.00 equiv) slowly dropwise. After $1.5 \mathrm{~h}$, the consumption of starting material was complete as determined by TLC (1:4 EtOAc: $\mathrm{CH}_{2} \mathrm{Cl}_{2}$ eluent). The reaction was quenched by the addition of saturated aqueous $\mathrm{NH}_{4} \mathrm{Cl}(0.5$ $\mathrm{mL})$ and saturated aqueous Rochelle salt $(0.5 \mathrm{~mL})$ and immediately removed from the cooling bath and allowed to warm to ambient temperature (ca. $23{ }^{\circ} \mathrm{C}$ ). After stirring for $1 \mathrm{~h}$, the reaction was diluted with $\mathrm{CH}_{2} \mathrm{Cl}_{2}(2.0 \mathrm{~mL})$ and poured onto $\mathrm{H}_{2} \mathrm{O}(3.0$ $\mathrm{mL})$. The organics were separated and the aqueous was extracted with $\mathrm{CH}_{2} \mathrm{Cl}_{2}(4 \times 1.5 \mathrm{~mL})$. The combined organics were dried over $\mathrm{MgSO}_{4}$, filtered, and concentrated in vacuo. The crude offwhite solid was purified by silica gel column chromatography (EtOAc eluent) to provide lactol $46(2 \mathrm{mg}, 40 \%$ yield) as an amorphous white solid: $\mathrm{R}_{f}=0.23$ (EtOAc eluent); ${ }^{1} \mathrm{H}$ NMR $\left(\mathrm{CDCl}_{3}, 400 \mathrm{MHz}\right) \delta 5.47(\mathrm{dd}, J=12.1,5.6 \mathrm{~Hz}, 1 \mathrm{H}), 5.39(\mathrm{~d}, J=$ $12.1 \mathrm{~Hz}, 1 \mathrm{H}), 4.82-4.77(\mathrm{~m}, 1 \mathrm{H}), 4.72(\mathrm{dt}, J=1.8,0.9 \mathrm{~Hz}, 1 \mathrm{H})$, $4.58-4.51(\mathrm{~m}, 1 \mathrm{H}), 4.22-4.13(\mathrm{~m}, 1 \mathrm{H}), 3.55(\mathrm{dd}, J=5.5,1.1 \mathrm{~Hz}$, $1 \mathrm{H}), 3.19$ (ddd, $J=7.7,6.2,3.8 \mathrm{~Hz}, 1 \mathrm{H}), 3.14-3.05(\mathrm{~m}, 1 \mathrm{H})$, $3.01-2.92(\mathrm{~m}, 2 \mathrm{H}), 2.47(\mathrm{dd}, J=14.6,6.8 \mathrm{~Hz}, 1 \mathrm{H}), 2.37(\mathrm{~s}, 1 \mathrm{H})$, $2.36-2.23(\mathrm{~m}, 2 \mathrm{H}), 2.21-2.13(\mathrm{~m}, 2 \mathrm{H}), 1.91$ (ddt, $J=14.1,10.3$, $5.1 \mathrm{~Hz}, 1 \mathrm{H}), 1.78(\mathrm{~s}, 3 \mathrm{H}), 1.55-1.43(\mathrm{~m}, 1 \mathrm{H}), 1.35(\mathrm{~s}, 3 \mathrm{H})$; ${ }^{13} \mathrm{C}\left\{{ }^{1} \mathrm{H}\right\}$ NMR $\left(\mathrm{CDCl}_{3}, 101 \mathrm{MHz}\right) \delta 148.7,129.7,128.1,109.9$, 99.4, 80.3, 76.0, 73.9, 71.4, 57.6, 53.2, 48.9, 43.4, 38.5, 38.0, 36.6, 27.8, 25.7, 21.0; IR (Neat Film, NaCl) 3388, 2925, 1660, 1445, 1260, 1098, 1027, 888, 800, $759 \mathrm{~cm}^{-1}$; HRMS (ES+) $\mathrm{m} / \mathrm{z}$ calc'd for $\mathrm{C}_{19} \mathrm{H}_{26} \mathrm{O}_{5}[\mathrm{M} \bullet]^{+}: 334.1780$, found 334.2023 ; $[\alpha]_{\mathrm{D}}{ }^{25.0}$ $+36.2^{\circ}\left(\right.$ c $\left.0.250, \mathrm{CHCl}_{3}\right)$.

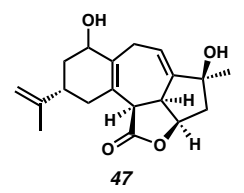

(2a $\left.R, 2 \mathrm{a}^{1} S, 4 S, 9 S, 10 \mathrm{~b} R\right)-4,7-d i h y d r o x y-4-m e t h y l-9-(p r o p-1-$ en-2-yl)-2a,2a ${ }^{1}, 3,4,6,7,8,9,10,10 b-d e c a h y d r o-1 H$ -

benzo[6,7]azuleno[1,8-bc] furan-1-one (47). To a stirred solution of diene 5 ( $35 \mathrm{mg}, 0.11 \mathrm{mmol}, 1.00$ equiv) in $\mathrm{CH}_{2} \mathrm{Cl}_{2}$ (4.5 
$\mathrm{mL})$ at $-78{ }^{\circ} \mathrm{C}(i$-PrOH/dry ice bath) was added DIBAL (121 $\mathrm{mL}, 1.00 \mathrm{M}$ in toluene, 1.10 equiv) slowly dropwise. After $2 \mathrm{~h}$, the reaction was quenched before the complete consumption of starting material, as determined by TLC (1:4 EtOAc: $\mathrm{CH}_{2} \mathrm{Cl}_{2}$ eluent), by the addition of saturated aqueous $\mathrm{NH}_{4} \mathrm{Cl}(6.0 \mathrm{~mL})$ and saturated aqueous Rochelle salt $(6.0 \mathrm{~mL})$ and immediately removed from the cooling bath and allowed to warm to ambient temperature (ca. $23^{\circ} \mathrm{C}$ ). After stirring for $1 \mathrm{~h}$, the reaction was diluted with $\mathrm{CH}_{2} \mathrm{Cl}_{2}(10 \mathrm{~mL})$ and poured onto $\mathrm{H}_{2} \mathrm{O}(30 \mathrm{~mL})$. The organics were separated and the aqueous was extracted with $\mathrm{CH}_{2} \mathrm{Cl}_{2}(4 \times 20 \mathrm{~mL})$. The combined organics were dried over $\mathrm{MgSO}_{4}$, filtered, and concentrated in vacuo. The crude off-white solid was purified by silica gel column chromatography $(60 \%$ EtOAc in hexanes eluent) to provide allylic alcohol 47 (4 mg, $11 \%$ yield $)$ as an amorphous white solid: $\mathrm{R}_{f}=0.28(1: 1$ EtOAc: $\mathrm{CH}_{2} \mathrm{Cl}_{2}$ eluent); ${ }^{1} \mathrm{H} \mathrm{NMR}\left(\mathrm{CDCl}_{3}, 400 \mathrm{MHz}\right) \delta 6.22$ (dt, $J$ $=8.2,3.3 \mathrm{~Hz}, 1 \mathrm{H}), 4.83-4.69(\mathrm{~m}, 3 \mathrm{H}), 4.20(\mathrm{q}, J=7.0,6.5 \mathrm{~Hz}$, $1 \mathrm{H}), 3.73(\mathrm{dq}, J=6.0,2.9 \mathrm{~Hz}, 1 \mathrm{H}), 3.36(\mathrm{dd}, J=6.9,3.0 \mathrm{~Hz}$, $1 \mathrm{H}), 3.27-3.14(\mathrm{~m}, 1 \mathrm{H}), 2.95-2.78(\mathrm{~m}, 2 \mathrm{H}), 2.43$ (d, $J=15.4$ $\mathrm{Hz}, 1 \mathrm{H}), 2.40-2.31(\mathrm{~m}, 1 \mathrm{H}), 2.25-2.14(\mathrm{~m}, 1 \mathrm{H}), 2.02(\mathrm{dd}, J=$ $15.5,4.1 \mathrm{~Hz}, 1 \mathrm{H}), 1.97(\mathrm{~s}, 1 \mathrm{H}), 1.87$ (ddt, $J=14.2,10.6,3.2 \mathrm{~Hz}$, $1 \mathrm{H}), 1.77$ (s, 3H), 1.53 (dd, $J=12.2,9.4 \mathrm{~Hz}, 1 \mathrm{H}), 1.41(\mathrm{~s}, 3 \mathrm{H})$; ${ }^{13} \mathrm{C}\left\{{ }^{1} \mathrm{H}\right\}$ NMR $\left(\mathrm{CDCl}_{3}, 101 \mathrm{MHz}\right) \delta 174.7,148.7,148.3,133.2$, 128.0, 127.1, 109.6, 82.3, 78.6, 73.0, 49.1, 47.8, 46.0, 38.7, 38.1, 37.0, 28.9, 28.4, 21.1; IR (Neat Film, NaCl) 3379, 2925, 2855, $1761,1442,1373,1283,1225,1151,1102,1048,987,963,890$, 849, 805, $756 \mathrm{~cm}^{-1}$; HRMS (ES+) $\mathrm{m} / z$ calc'd for $\mathrm{C}_{19} \mathrm{H}_{25} \mathrm{O}_{4}$ $[\mathrm{M}+\mathrm{H}]^{+}: 317.1753$, found $317.1759 ;[\alpha]_{\mathrm{D}}{ }^{25.0}+62.5^{\circ}(c 0.200$, $\left.\mathrm{CHCl}_{3}\right)$.

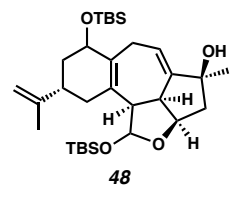

$\left(2 \mathrm{a} R, 2 \mathrm{a}^{1} S, 4 S, 9 S, 10 \mathrm{~b} R\right)-1,7-\mathrm{bis}(($ tert-

butyldimethylsilyl)oxy)-4-methyl-9-(prop-1-en-2-yl)-

2a,2a ${ }^{1}, 3,4,6,7,8,9,10,10 b$-decahydro- $1 H$ -

benzo[6,7]azuleno[1,8-bc] furan-4-ol (48). To a stirred solution of lactol 45 (11 mg, $0.035 \mathrm{mmol}, 1.00$ equiv) in $\mathrm{CH}_{2} \mathrm{Cl}_{2}(2.0 \mathrm{~mL})$ were added imidazole $(181 \mathrm{mg}, 2.66 \mathrm{mmol}, 76.0$ equiv) and DMAP (26 mg, $0.21 \mathrm{mmol}, 6.00$ equiv) sequentially, each as a solid in a single portion. After 2 minutes, to the colorless homogeneous solution was added TBSCl $(80 \mathrm{mg}, 0.53 \mathrm{mmol}, 15.1$ equiv) as a solid in one portion. After $16 \mathrm{~h}$, the consumption of starting material was complete as determined by TLC (1:1 EtOAc: $\mathrm{CH}_{2} \mathrm{Cl}_{2}$ eluent). The reaction mixture was diluted with hexanes $(6.0 \mathrm{~mL})$ and the white suspension was filtered over Celite $^{\circledR}$, washing with $30 \%$ EtOAc in hexanes eluent. The combined organics were concentrated in vacuo. The crude white solid was purified by silica gel column chromatography $(5 \%$ EtOAc in hexanes eluent) to afford bis-silyl ether $\mathbf{4 8}$ (17 mg, 89\% yield) as an amorphous white solid: $\mathrm{R}_{f}=0.43(1: 19$ EtOAc:Hexanes eluent); ${ }^{1} \mathrm{H}$ NMR $\left(\mathrm{CDCl}_{3}, 400 \mathrm{MHz}\right) \delta 6.13(\mathrm{dt}, J=8.5,3.4 \mathrm{~Hz}$, $1 \mathrm{H}), 5.27(\mathrm{~d}, J=5.4 \mathrm{~Hz}, 1 \mathrm{H}), 4.71(\mathrm{q}, J=1.7 \mathrm{~Hz}, 1 \mathrm{H}), 4.69(\mathrm{~d}, J$ $=1.7 \mathrm{~Hz}, 1 \mathrm{H}), 4.66(\mathrm{t}, J=3.2 \mathrm{~Hz}, 1 \mathrm{H}), 4.27(\mathrm{~d}, J=8.8 \mathrm{~Hz}, 1 \mathrm{H})$, $3.47-3.34(\mathrm{~m}, 2 \mathrm{H}), 3.05-2.92(\mathrm{~m}, 1 \mathrm{H}), 2.80(\mathrm{t}, J=6.1 \mathrm{~Hz}, 1 \mathrm{H})$, $2.66(\mathrm{dd}, J=18.5,8.5 \mathrm{~Hz}, 1 \mathrm{H}), 2.28(\mathrm{~d}, J=17.6 \mathrm{~Hz}, 1 \mathrm{H}), 2.22$ $2.11(\mathrm{~m}, 2 \mathrm{H}), 2.03$ (ddt, $J=11.3,6.4,2.4 \mathrm{~Hz}, 1 \mathrm{H}), 1.89-1.76(\mathrm{~m}$, 2H), 1.74-1.66 (m, 3H), 1.52-1.39 (m, 1H), $1.35(\mathrm{~s}, 3 \mathrm{H}), 0.92(\mathrm{~s}$, 9H), 0.87 (s, 9H), $0.13(\mathrm{~s}, 3 \mathrm{H}), 0.10(\mathrm{~s}, 3 \mathrm{H}), 0.09$ (s, 3H), $0.06(\mathrm{~s}$, $3 \mathrm{H}) ;{ }^{13} \mathrm{C}\left\{{ }^{1} \mathrm{H}\right\}$ NMR $\left(\mathrm{CDCl}_{3}, 101 \mathrm{MHz}\right) \delta 150.8,148.8,132.5$, $129.7,126.7,109.3,104.0,83.7,78.6,74.2,55.8,50.5,46.3$, $39.6,38.7,36.3,28.2,26.2,25.9,25.8,20.5,18.4,17.9,-3.4$, 3.6, -4.7, -4.9; IR (Neat Film, NaCl) 2928, 2856, 1461, 1256, $1103,1066,1026,1002,885,837,778 \mathrm{~cm}^{-1}$; HRMS (FAB+) $\mathrm{m} / z$ calc'd for $\mathrm{C}_{31} \mathrm{H}_{53} \mathrm{O}_{4} \mathrm{Si}_{2}\left[(\mathrm{M}+\mathrm{H})-\mathrm{H}_{2}\right]^{+}:$545.3482, found 545.3474; $[\alpha]_{\mathrm{D}}^{25.0}+94.6^{\circ}\left(c 0.200, \mathrm{CHCl}_{3}\right)$.

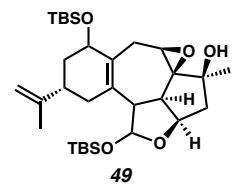

$\left(2 S, 2 \mathrm{a} S, 2 \mathrm{a}^{1} R, 3 \mathrm{a} R, 7 S, 8 \mathrm{~b} R, 10 \mathrm{a} R\right)-5,9-\mathrm{bis}(($ tert butyldimethylsilyl)oxy)-2-methyl-7-(prop-1-en-2-yl)$1,2,2 a^{1}, 3 a, 4,5,6,7,8,8 b, 9,10 a-$

dodecahydrobenzo $[6,7]$ oxireno $\left[2^{\prime}, 3^{\prime}: 3 \mathrm{a}, 4\right]$ azuleno[1,8-

bc]furan-2-ol (49). To a colorless stirred solution of bis-silyl ether 48 (20 mg, $0.036 \mathrm{mmol}, 1.00$ equiv) in a vial open to air in benzene $(2.0 \mathrm{~mL})$ was added $\mathrm{VO}(\text { acac })_{2}(1.0 \mathrm{mg}, 0.0036 \mathrm{mmol}$, 0.01 equiv). After 5 minutes, to this dark green solution was added $t$-butyl hydroperoxide (TBHP, $20 \mathrm{~mL}, 0.10 \mathrm{mmol}, 2.78$ equiv) as a $5 \mathrm{M}$ solution in decane dropwise causing the reaction to immediately become deep ruby red. After $1 \mathrm{~h}$, the reaction had lost all red color and become pale yellow and the consumption of starting material was complete as determined by TLC (1:19 EtOAc:Hexanes eluent). The reaction was concentrated in vacuo and the crude tan solid was purified by silica gel column chromatography (10\% EtOAc in hexanes eluent) to afford epoxide 49 (18 mg, 90\% yield) as an amorphous white solid: $\mathrm{R}_{f}=0.17(1: 19$ EtOAc:Hexanes eluent); ${ }^{1} \mathrm{H} \mathrm{NMR}\left(\mathrm{CDCl}_{3}, 400 \mathrm{MHz}\right) \delta 5.27(\mathrm{~d}$, $J=5.0 \mathrm{~Hz}, 1 \mathrm{H}), 4.71(\mathrm{t}, J=1.6 \mathrm{~Hz}, 1 \mathrm{H}), 4.68(\mathrm{dt}, J=1.9,0.9$ $\mathrm{Hz}, 1 \mathrm{H}), 4.53(\mathrm{td}, J=4.0,2.0 \mathrm{~Hz}, 1 \mathrm{H}), 4.23(\mathrm{t}, J=8.0 \mathrm{~Hz}, 1 \mathrm{H})$, $3.22-3.17(\mathrm{~m}, 1 \mathrm{H}), 2.96(\mathrm{dd}, J=6.0,3.6 \mathrm{~Hz}, 1 \mathrm{H}), 2.82-2.65(\mathrm{~m}$, $3 \mathrm{H}), 2.62$ (s, 1H), 2.43 (d, $J=17.0 \mathrm{~Hz}, 1 \mathrm{H}), 2.25-2.09$ (m, 3H), 2.02 (ddt, $J=11.3,6.4,2.2 \mathrm{~Hz}, 1 \mathrm{H}), 1.79-1.71(\mathrm{~m}, 1 \mathrm{H}), 1.70(\mathrm{t}$, $J=1.1 \mathrm{~Hz}, 3 \mathrm{H}), 1.39$ (ddd, $J=13.1,12.1,10.0 \mathrm{~Hz}, 1 \mathrm{H}), 1.28$ (s, $3 \mathrm{H}), 0.92(\mathrm{~s}, 9 \mathrm{H}), 0.87(\mathrm{~s}, 9 \mathrm{H}), 0.13(\mathrm{~s}, 3 \mathrm{H}), 0.11(\mathrm{~s}, 3 \mathrm{H}), 0.10(\mathrm{~s}$, $3 \mathrm{H}), 0.08(\mathrm{~s}, 3 \mathrm{H}) ;{ }^{13} \mathrm{C}\left\{{ }^{1} \mathrm{H}\right\}$ NMR $\left(\mathrm{CDCl}_{3}, 101 \mathrm{MHz}\right) \delta 148.8$, $130.4,126.1,109.3,103.3,80.2,75.6,75.2,71.0,57.6,54.8$, $46.7,46.6,39.1,38.7,36.5,28.2,27.2,26.2,25.9,20.5,18.4$, $17.9,-3.5,-3.6,-4.7,-4.9$; IR (Neat Film, NaCl) 3441, 2955, 2928, 2856, 1471, 1257, 1093, 1066, 1018, 957, 878, 833, 776 $\mathrm{cm}^{-1}$; HRMS (FAB+) $\mathrm{m} / z$ calc'd for $\mathrm{C}_{31} \mathrm{H}_{53} \mathrm{O}_{5} \mathrm{Si}_{2}\left[(\mathrm{M}+\mathrm{H})-\mathrm{H}_{2}\right]^{+}$: 561.3432 , found 561.3441; $[\alpha]_{\mathrm{D}}^{25.0}+88.4^{\circ}\left(c 0.150, \mathrm{CHCl}_{3}\right)$.

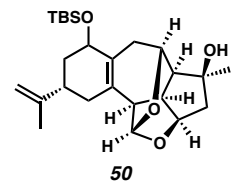

$\left(1 S, 2 \mathrm{a} R, 2 \mathrm{a}^{1} R, 4 S, 4 \mathrm{a} S, 5 R, 9 S, 10 \mathrm{~b} R\right)-7-((t e r t-$ butyldimethylsilyl)oxy)-4-methyl-9-(prop-1-en-2-yl)-

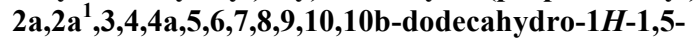
epoxybenzo[6,7]azuleno[1,8-bc]furan-4-ol (50).

Preparation of 0.50 M Solution of Titanocene Monochloride $\left(\mathrm{Cp}_{2} \mathrm{TiCl}\right)$

Into a thoroughly flame-dried Schlenk tube under an overpressure of argon was charged with manganese $(0)$ dust $(543 \mathrm{mg}$, $9.90 \mathrm{mmol}, 3.00$ equiv) and titanocene dichloride $\left(\mathrm{Cp}_{2} \mathrm{TiCl}_{2}, 822\right.$ $\mathrm{mg}, 3.30 \mathrm{mmol}, 1.00$ equiv). The flask was then evacuated and back filled with argon ( 3 x 5 minute cycles). To the reaction vessel was then added THF $(6.6 \mathrm{~mL})$ that had previously been sparged with argon for 60 minutes and stirring commenced. After $1.5 \mathrm{~h}$, the bright red reaction mixture had become yellowgreen and stirring was halted. After 30 minutes, the supernatant was used as a $0.50 \mathrm{M}$ stock solution of $\mathrm{Cp}_{2} \mathrm{TiCl}$.

Epoxide Opening with $\mathrm{Cp}_{2} \mathrm{TiCl}$

A stirred solution of epoxide $49(18 \mathrm{mg}, 0.042 \mathrm{mmol}, 1.00$ equiv) in THF (3.0 mL) was sparged with argon for $1 \mathrm{~h}$, result- 
ing in a reaction volume of $2.0 \mathrm{~mL}$. The homogeneous, off-white reaction mixture was then cooled to $-78{ }^{\circ} \mathrm{C}(i-\mathrm{PrOH} / \mathrm{dry}$ ice bath) followed by the addition of $\mathrm{H}_{2} \mathrm{O}(63 \mu \mathrm{L}, 3.50 \mathrm{mmol}, 83.3$ equiv). After stirring for 5 minutes, $\mathrm{Cp}_{2} \mathrm{TiCl}(0.88 \mathrm{mmol}, 0.50 \mathrm{M}$ in THF, 21.0 equiv) was added dropwise over 3 minutes. After $2.5 \mathrm{~h}$, the reaction vessel was warmed to $0{ }^{\circ} \mathrm{C}$ (ice $/ \mathrm{H}_{2} \mathrm{O}$ bath). After an additional $5.5 \mathrm{~h}$, the Schlenk tube was removed from the cooling bath and allowed to warm to ambient temperature. After an additional $42 \mathrm{~h}$, the consumption of starting material was complete as determined by TLC (3:17 Acetone:Hexanes eluent). The reaction was quenched by the addition of saturated $\mathrm{NaH}_{2} \mathrm{PO}_{4}(0.25 \mathrm{~mL})$ and brine $(0.25 \mathrm{~mL})$, sparged with compressed air for 5 minutes, and allowed to stir for an additional 15 minutes. The reaction mixture was then filtered through a Celite ${ }^{\mathbb{R}}$ plug, washing with $50 \%$ acetone in hexanes eluent. The combined organics were concentrated in vacuo and immediately purified by silica gel column chromatography $(8 \%$ acetone in hexanes eluent) to furnish acetal $\mathbf{5 0}$ (16 $\mathrm{mg}, 89 \%$ yield) as an amorphous white solid: $\mathrm{R}_{f}=0.22$ (3:17 Acetone:Hexanes eluent); ${ }^{1} \mathrm{H}$ NMR $\left(\mathrm{CDCl}_{3}, 400 \mathrm{MHz}\right) \delta 5.46(\mathrm{dd}, J=3.7,1.0 \mathrm{~Hz}$, $1 \mathrm{H}), 4.80-4.69(\mathrm{~m}, 2 \mathrm{H}), 4.44(\mathrm{ddd}, J=6.0,1.9,0.8 \mathrm{~Hz}, 1 \mathrm{H})$, $4.27-4.15(\mathrm{~m}, 2 \mathrm{H}), 3.27(\mathrm{~d}, J=1.3 \mathrm{~Hz}, 1 \mathrm{H}), 3.14(\mathrm{dt}, J=9.9,3.3$ $\mathrm{Hz}, 1 \mathrm{H}), 2.65-2.56(\mathrm{~m}, 1 \mathrm{H}), 2.50-2.41(\mathrm{~m}, 1 \mathrm{H}), 2.39(\mathrm{~d}, J=9.9$ $\mathrm{Hz}, 1 \mathrm{H}), 2.35-2.27(\mathrm{~m}, 2 \mathrm{H}), 2.24(\mathrm{dd}, J=14.9,1.1 \mathrm{~Hz}, 1 \mathrm{H})$, 2.17 (dddd, $J=16.1,11.3,5.5,2.3 \mathrm{~Hz}, 1 \mathrm{H}$ ), 1.98 (dddt, $J=13.4$, 7.5, 4.7, $2.3 \mathrm{~Hz}, 2 \mathrm{H}), 1.87$ (ddd, $J=14.5,3.2,1.1 \mathrm{~Hz}, 1 \mathrm{H}), 1.73$ (t, $J=1.1 \mathrm{~Hz}, 3 \mathrm{H}), 1.48$ (ddd, $J=13.1,12.3,10.2 \mathrm{~Hz}, 1 \mathrm{H}), 1.33$ $(\mathrm{d}, J=1.1 \mathrm{~Hz}, 3 \mathrm{H}), 0.91(\mathrm{~s}, 9 \mathrm{H}), 0.09(\operatorname{app~s}, 6 \mathrm{H}) ;{ }^{13} \mathrm{C}\left\{{ }^{1} \mathrm{H}\right\}$ NMR $\left(\mathrm{CDCl}_{3}, 101 \mathrm{MHz}\right) \delta 148.7,133.6,126.9,109.5,103.6$, $84.9,82.1,72.4,65.8,54.3,51.0,50.0,48.3,40.2,39.8,39.5$, $37.8,29.9,26.1,20.5,18.4,-3.9,-4.6$; IR (Neat Film, NaCl) $3440,2928,2856,1463,1367,1258,1211,1068,1046,958$, 869, 836, $776 \mathrm{~cm}^{-1}$; HRMS (FAB+) $\mathrm{m} / z$ calc'd for $\mathrm{C}_{25} \mathrm{H}_{39} \mathrm{O}_{4} \mathrm{Si}$ $\left[(\mathrm{M}+\mathrm{H})-\mathrm{H}_{2}\right]^{+}: 431.2618$, found $431.2622 ;[\alpha]_{\mathrm{D}}^{25.0}+44.3^{\circ}(c$ $0.150, \mathrm{CHCl}_{3}$ ).

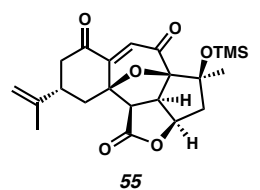

55

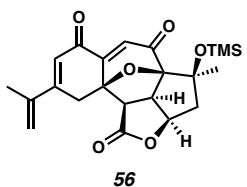

56 $\left(2 \mathrm{a} R, 2 \mathrm{a}^{1} R, 4 S, 4 \mathrm{a} R, 9 S, 10 \mathrm{a} R, 10 \mathrm{~b} R\right)-4-m e t h y l-9-(p r o p-1-e n-2-$ yl)-4-((trimethylsilyl)oxy)-2a $\mathrm{a}^{1}, 3,4,9,10,10 \mathrm{~b}-\mathrm{hexahydro}-5 \mathrm{H}$ 4a,10a-epoxybenzo[6,7]azuleno[1,8-bc] furan-1,5,7(2aH,8H)trione (55) and $\left(2 \mathrm{a} R, 2 \mathrm{a}^{1} R, 4 S, 4 \mathrm{a} R, 10 \mathrm{a} R, 10 \mathrm{~b} R\right)-4-m e t h y l-9-$ (prop-1-en-2-yl)-4-((trimethylsilyl)oxy)-2a ${ }^{1}, 3,4,10 b-$ tetrahydro-5H-4a,10a-epoxybenzo[6,7]azuleno[1,8-bc]furan1,5,7(2aH,10H)-trione (56). To a stirred solution of ketopyran 9 (15 mg, $0.043 \mathrm{mmol}, 1.00$ equiv) in $\mathrm{CH}_{2} \mathrm{Cl}_{2}(0.4 \mathrm{~mL})$ at $0{ }^{\circ} \mathrm{C}$ (ice $/ \mathrm{H}_{2} \mathrm{O}$ bath) was added $\mathrm{Et}_{3} \mathrm{~N}(0.12 \mathrm{~mL}, 0.87 \mathrm{mmol}, 20.0$ equiv) dropwise. After 2 minutes, TMSOTf ( $24 \mathrm{~mL}, 0.13 \mathrm{mmol}$, 3.00 equiv) was added slowly dropwise. After $1.5 \mathrm{~h}$, TMSOTf ( $24 \mathrm{~mL}, 0.13 \mathrm{mmol}, 3.00$ equiv) was added slowly dropwise. After an additional $1.5 \mathrm{~h}$, the consumption of starting material was complete as determined by TLC (1:1 EtOAc: $\mathrm{CH}_{2} \mathrm{Cl}_{2}$ eluent). The reaction was quenched by the addition of saturated aqueous $\mathrm{Na}-$ $\mathrm{HCO}_{3}(1.5 \mathrm{~mL})$ and the biphasic mixture was immediately removed from the cooling bath and allowed to warm to ambient temperature (ca. $23{ }^{\circ} \mathrm{C}$ ). The reaction mixture was diluted with $\mathrm{Et}_{2} \mathrm{O}(2 \mathrm{~mL})$ and poured onto $\mathrm{H}_{2} \mathrm{O}(3 \mathrm{~mL})$. The organics were separated and the aqueous was extracted with $\mathrm{Et}_{2} \mathrm{O}(5 \times 2 \mathrm{~mL})$. The combined organics were dried over $\mathrm{MgSO}_{4}$, filtered, and concentrated in vacuo. The crude amorphous white solid was carried on without further purification.
To a stirred solution of the crude white solid in DMSO (1.5 $\mathrm{mL}$ ) was added $\mathrm{Pd}(\mathrm{OAc})_{2}(30 \mathrm{mg}, 0.13 \mathrm{mmol}, 3.11$ equiv) as a solid in single portion. After $7 \mathrm{~h}$, the consumption of starting material was complete as determined by TLC (3:3 EtOAc:Hexanes eluent). The dark brown reaction mixture was diluted with $\mathrm{H}_{2} \mathrm{O}$ $(8 \mathrm{~mL})$ and the aqueous was extracted with $\mathrm{CH}_{2} \mathrm{Cl}_{2}(5 \times 10 \mathrm{~mL})$ followed by EtOAc $(2 \times 5 \mathrm{~mL})$. The combined organics were dried over $\mathrm{MgSO}_{4}$, filtered, and concentrated in vacuo. The crude brown solid was purified by semi-preparative HPLC (Agilent ZORBAX RX-SIL silica gel column, $5 \mathrm{~mm}$ mesh, $9.4 \mathrm{~mm}$ x $250 \mathrm{~mm}$, mobile phase: $20 \%$ EtOAc in hexanes, flow rate: 7.00 $\mathrm{mL} / \mathrm{min}$ ) to provide vinylogous diketone $\mathbf{5 5}$ (retention time 9.9 minutes, $10 \mathrm{mg}, 56 \%$ yield) as an amorphous white solid and polyunsaturated diketone 56 (retention time 11.4 minutes, $8 \mathrm{mg}$, $44 \%$ yield) as an amorphous white solid.

Vinylogous Diketone 55. $\mathrm{R}_{f}=0.37$ (3:7 EtOAc:Hexanes eluent); ${ }^{1} \mathrm{H}$ NMR $\left(\mathrm{CDCl}_{3}, 600 \mathrm{MHz}\right) \delta 6.26(\mathrm{q}, J=0.7 \mathrm{~Hz}, 1 \mathrm{H})$, 4.93 (dddd, $J=9.4,8.3,6.8,1.5 \mathrm{~Hz}, 1 \mathrm{H}), 4.89(\mathrm{~s}, 1 \mathrm{H}), 4.84-4.82$ $(\mathrm{m}, 1 \mathrm{H}), 3.35(\mathrm{td}, J=8.8,1.5 \mathrm{~Hz}, 1 \mathrm{H}), 3.15(\mathrm{dd}, J=8.8,1.5 \mathrm{~Hz}$, $1 \mathrm{H}), 2.77-2.61(\mathrm{~m}, 3 \mathrm{H}), 2.49-2.38(\mathrm{~m}, 2 \mathrm{H}), 2.31$ (ddd, $J=12.6$, 7.7, $1.4 \mathrm{~Hz}, 1 \mathrm{H}), 2.19$ (dtd, $J=15.1,2.6,1.6 \mathrm{~Hz}, 1 \mathrm{H}), 1.81(\mathrm{~m}$, $3 \mathrm{H}), 1.66(\mathrm{~s}, 3 \mathrm{H}), 0.11(\mathrm{~s}, 9 \mathrm{H}) ;{ }^{13} \mathrm{C}\left\{{ }^{1} \mathrm{H}\right\}$ NMR $\left(\mathrm{CDCl}_{3}, 126\right.$ $\mathrm{MHz}) \delta 199.8,194.3,173.4,156.2,145.2,127.7,111.6,96.7$, 86.1, 81.2, 77.8, 54.0, 49.9, 47.1, 44.9, 37.8, 35.3, 27.1, 20.9, 2.4; IR (Neat Film, NaCl) 2960, 2928, 1765, 1702, 1252, 1193, 1069, 1046, 869, $841 \mathrm{~cm}^{-1}$; HRMS (FAB+) $\mathrm{m} / z$ calc'd for $\mathrm{C}_{22} \mathrm{H}_{29} \mathrm{O}_{6} \mathrm{Si}[\mathrm{M}+\mathrm{H}]^{+}: 417.1733$, found $417.1741 ;[\alpha]_{\mathrm{D}}{ }^{25.0}-16.9^{\circ}$ (c $0.100, \mathrm{CHCl}_{3}$ ).

Polyunsaturated Diketone 56. $\mathrm{R}_{f}=0.37 \quad(3: 7$ EtOAc:Hexanes); ${ }^{1} \mathrm{H} \mathrm{NMR}\left(\mathrm{CDCl}_{3}, 400 \mathrm{MHz}\right) \delta 6.64(\mathrm{~d}, J=0.7$ $\mathrm{Hz}, 1 \mathrm{H}), 6.44(\mathrm{~d}, J=2.5 \mathrm{~Hz}, 1 \mathrm{H}), 5.75(\mathrm{~s}, 1 \mathrm{H}), 5.57$ (dd, $J=1.9$, $1.0 \mathrm{~Hz}, 1 \mathrm{H}), 4.93$ (tdd, $J=9.5,8.6,7.7,3.4 \mathrm{~Hz}, 1 \mathrm{H}), 3.45-3.36$ $(\mathrm{m}, 2 \mathrm{H}), 3.26(\mathrm{dd}, J=8.8,0.6 \mathrm{~Hz}, 1 \mathrm{H}), 3.01(\mathrm{dd}, J=17.0,2.6$ $\mathrm{Hz}, 1 \mathrm{H}), 2.48-2.38(\mathrm{~m}, 1 \mathrm{H}), 2.37-2.30(\mathrm{~m}, 1 \mathrm{H}), 2.08(\mathrm{~d}, J=1.3$ $\mathrm{Hz}, 3 \mathrm{H}), 1.68(\mathrm{~d}, J=1.2 \mathrm{~Hz}, 3 \mathrm{H}), 0.16-0.08(\mathrm{~m}, 9 \mathrm{H}) ;{ }^{13} \mathrm{C}\left\{{ }^{1} \mathrm{H}\right\}$ NMR $\left(\mathrm{CDCl}_{3}, 101 \mathrm{MHz}\right) \delta 193.8,185.0,173.2,157.2,151.4$, $141.1,127.0,124.9,122.9,95.6,86.5,80.8,78.0,52.8,50.2$, 47.2, 30.3, 26.8, 20.6, 2.4; IR (Neat Film, NaCl) 2959, 1770, 1702, 1660, 1611, 1378, 1252, 1179, 1066, 1036, 870, 842, 759 $\mathrm{cm}^{-1}$; HRMS (FAB+) $\mathrm{m} / z$ calc'd for $\mathrm{C}_{22} \mathrm{H}_{27} \mathrm{O}_{6} \mathrm{Si}[\mathrm{M}+\mathrm{H}]^{+}$: 415.1577, found 415.1588; $[\alpha]_{\mathrm{D}}^{25.0}+70.9^{\circ}\left(c 0.100, \mathrm{CHCl}_{3}\right)$.

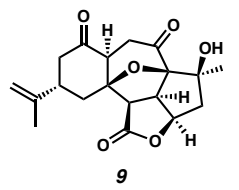

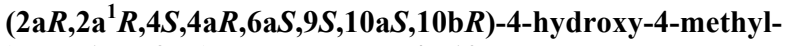
9-(prop-1-en-2-yl)octahydro-5H-4a,10aepoxybenzo[6,7]azuleno[1,8-bc] furan-1,5,7(2aH,8H)-trione (9).

Preparation of a 0.07 M Stock Solution $\mathrm{SmI}_{2}$

Into a Schlenk tube was added freshly filed samarium metal (150 mg, $1.00 \mathrm{mmol}, 1.41$ equiv). The reaction vessel was then thoroughly flame-dried, backfilled with argon, and allowed to cool to ambient temperature (ca. $23{ }^{\circ} \mathrm{C}$ ). To the reaction vessel was then added THF $(10.0 \mathrm{~mL})$ that had previously been sparged with argon for 60 minutes and cooled to $0{ }^{\circ} \mathrm{C}$ (ice $/ \mathrm{H}_{2} \mathrm{O}$ bath) with stirring. $\mathrm{EtI}_{2}(200 \mathrm{mg}, 0.71 \mathrm{mmol}, 1.00$ equiv) was then added in separate $100 \mathrm{mg}$ portions 30 minutes apart. After the addition of the second portion, the Schlenk tube was removed from the cooling bath, allowed to warm to ambient temperature, and the pale yellow solution was stirred overnight (ca. $14 \mathrm{~h}$ ) causing the reaction to become deep blue, indicating to formation of $\mathrm{SmI}_{2}$. 


\section{Reduction of Vinlyogous Diketone $\mathbf{5 5}$}

A stirred solution of vinylogous diketone $55(4 \mathrm{mg}, 0.0010$ mmol, 1.00 equiv) in THF $(1.5 \mathrm{~mL})$ was sparged to $1.5 \mathrm{~h}$, leaving a reaction volume of $0.25 \mathrm{~mL}$. The resultant colorless reaction mixture was then cool to $-78{ }^{\circ} \mathrm{C}(i-\mathrm{PrOH} /$ dry ice bath $)$ at which time $\mathrm{SmI}_{2}$ ( $0.010 \mathrm{mmol}, 0.07 \mathrm{M}$ in THF, 10.0 equiv) was added dropwise. After 20 minutes, the consumption of starting material was complete as determined by TLC (1:4 EtOAc: $\mathrm{CH}_{2} \mathrm{Cl}_{2}$ eluent). To the reaction mixture was then added TBAF ( $0.01 \mathrm{mmol}, 1.0 \mathrm{M}$ in THF, 10.0 equiv). After 10 minutes, the reaction was quenched by addition of $\mathrm{H}_{2} \mathrm{O}(50 \mathrm{~mL})$, removed from the cooling bath, and allowed to warm to ambient temperature. The dark yellow reaction mixture was then filtered through a pad of silica gel $\left(50 \% \mathrm{EtOAc}\right.$ in $\mathrm{CH}_{2} \mathrm{Cl}_{2}$ eluent), and concentrated in vacuo. The crude dark gold solid was purified by silica gel column chromatography ( $20 \%$ EtOAc in $\mathrm{CH}_{2} \mathrm{Cl}_{2}$ eluent) to afford ketopyran 9 (3 mg, $75 \%$ yield) as a crystalline white solid: characterization data match those reported previously. ${ }^{8}$

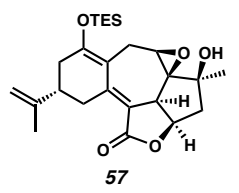

$\left(2 S, 2 \mathrm{a} S, 2 \mathrm{a}^{1} R, 3 \mathrm{a} R, 7 S, 10 \mathrm{a} R\right)$-2-hydroxy-2-methyl-7-(prop-1en-2-yl)-5-((triethylsilyl)oxy)-1,2a ${ }^{1}, 3 a, 4,6,7,8,10 a-$ octahydrobenzo[6,7]oxireno[ $\left.2^{\prime}, 3^{\prime}: 3 a, 4\right]$ azuleno[1,8-bc] furan9(2H)-one (57). To a stirred solution of ent-isoineleganolide A (13, $5 \mathrm{mg}, 0.015 \mathrm{mmol}, 1.00$ equiv) in $\mathrm{CH}_{2} \mathrm{Cl}_{2}(0.5 \mathrm{~mL})$ was added DMAP (7 mg, $0.057 \mathrm{mmol}, 3.83$ equiv) as a solid in one portion. After 2 minutes, the reaction mixture had become a completely homogenous pale yellow solution, and TESCl (25 $\mathrm{mL}, 0.15 \mathrm{mmol}, 10.0$ equiv) was added quickly dropwise. After $4 \mathrm{~h}$, the consumption of starting material was complete as determined by TLC (1:4 EtOAc: $\mathrm{CH}_{2} \mathrm{Cl}_{2}$ eluent). The reaction was quenched by the addition of saturated aqueous $\mathrm{NaHCO}_{3}(50$ $\mathrm{mL}$ ). After 5 minutes, the white suspension was filtered through a pad of silica gel (20\% EtOAc in $\mathrm{CH}_{2} \mathrm{Cl}_{2}$ eluent). The combined organics were concentrated in vacuo and the resultant crude white solid was purified by silica gel column chromatography (30\% EtOAc in hexanes eluent) to provide intermediate enol ether 57 (1.5 mg, $50 \%$ yield) as an amorphous white solid: $\mathrm{R}_{f}=$ 0.24 (3:7 EtOAc:Hexanes eluent); ${ }^{1} \mathrm{H}$ NMR $\left(\mathrm{CDCl}_{3}, 400 \mathrm{MHz}\right) \delta$ 4.82-4.70 (m, 3H), 4.04-3.95 (m, 1H), 3.91-3.85 (m, 1H), 3.68 $(\mathrm{dd}, J=16.0,6.6 \mathrm{~Hz}, 1 \mathrm{H}), 3.49(\mathrm{dd}, J=6.5,0.7 \mathrm{~Hz}, 1 \mathrm{H}), 2.57$ (dd, $J=12.9,7.0 \mathrm{~Hz}, 1 \mathrm{H}), 2.51-2.24(\mathrm{~m}, 6 \mathrm{H}), 1.97$ (dd, $J=12.9$, $8.2 \mathrm{~Hz}, 1 \mathrm{H}), 1.76(\mathrm{dd}, J=1.5,0.8 \mathrm{~Hz}, 3 \mathrm{H}), 1.31(\mathrm{~d}, J=1.0 \mathrm{~Hz}$, $3 \mathrm{H}), 1.02(\mathrm{t}, J=7.9 \mathrm{~Hz}, 9 \mathrm{H}), 0.75(\mathrm{qd}, J=7.9,0.8 \mathrm{~Hz}, 6 \mathrm{H})$; ${ }^{13} \mathrm{C}\left\{{ }^{1} \mathrm{H}\right\}$ NMR $\left(\mathrm{CDCl}_{3}, 101 \mathrm{MHz}\right) \delta 171.0,160.7,154.7,147.2$, $114.7,110.5,110.2,73.8,72.9,71.5,53.9,48.8,42.4,39.9,36.8$, 30.7, 23.6, 23.0, 21.2, 6.8, 5.9; IR (Neat Film, NaCl) 3478, 2960, 1728, 1586, 1449, 1345, 1192, 1112, 1046, 961, 937, 889, 790, $764 \mathrm{~cm}^{-1}$; HRMS (FAB+) m/z calc'd for $\mathrm{C}_{25} \mathrm{H}_{37} \mathrm{O}_{5} \mathrm{Si}[\mathrm{M}+\mathrm{H}]^{+}$: 445.2410, found 445.2419; $[\alpha]_{\mathrm{D}}^{25.0}+229.2^{\circ}\left(c 0.100, \mathrm{CHCl}_{3}\right)$.

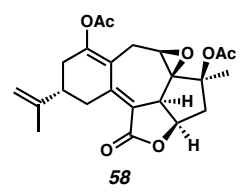

$\left(2 S, 2 \mathrm{a} S, 2 \mathrm{a}^{1} R, 3 \mathrm{a} R, 7 S, 10 \mathrm{a} R\right)$-2-methyl-9-oxo-7-(prop-1-en-2yl)-1,2,2a ${ }^{1}, 3 a, 4,6,7,8,9,10 a-$

decahydrobenzo[6,7]oxireno[ $\left[2^{\prime}, 3^{\prime}: 3 \mathrm{a}, 4\right]$ azuleno[1,8-bc]furan2,5-diyl diacetate (58). To a stirred solution of entisoineleganolide A $(\mathbf{1 3}, 10 \mathrm{mg}, 0.030 \mathrm{mmol}, 1.00$ equiv) in
$\mathrm{CH}_{2} \mathrm{Cl}_{2}(1.0 \mathrm{~mL})$ was added DMAP $(14 \mathrm{mg}, 0.11 \mathrm{mmol}, 3.67$ equiv) as a solid in one portion. After 2 minutes, the reaction mixture had become a completely homogenous pale yellow solution, and $\mathrm{Ac}_{2} \mathrm{O}(30 \mathrm{~mL}, 0.32 \mathrm{mmol}, 10.7$ equiv) was added quickly dropwise. After $2 \mathrm{~h}$, the consumption of starting material was complete as determined by TLC (1:4 EtOAc: $\mathrm{CH}_{2} \mathrm{Cl}_{2}$ eluent). The reaction was diluted with $\mathrm{CH}_{2} \mathrm{Cl}_{2}(3 \mathrm{~mL})$ and poured onto saturated aqueous $\mathrm{NaHCO}_{3}(3 \mathrm{~mL})$. The organics were separated and the aqueous was extracted with $\mathrm{CH}_{2} \mathrm{Cl}_{2}(2 \times 5 \mathrm{~mL})$. The combined organics were dried over $\mathrm{MgSO} 4$, filtered, and concentrated in vacuo. The crude golden solid was purified by silica gel column chromatography $\left(50 \%\right.$ EtOAc with $0.5 \% \mathrm{Et}_{3} \mathrm{~N}$ in hexanes eluent) to provide dienol acetate $\mathbf{5 8}(11 \mathrm{mg}, 85 \%$ yield) as an amorphous white solid: $\mathrm{R}_{f}=0.42$ (1:1 EtOAc:Hexanes eluent); ${ }^{1} \mathrm{H}$ NMR $\left(\mathrm{CDCl}_{3}, 400 \mathrm{MHz}\right) \delta 4.84$ (ddd, $J=9.4,7.9,7.2$ $\mathrm{Hz}, 1 \mathrm{H}), 4.80-4.76(\mathrm{~m}, 2 \mathrm{H}), 3.96(\mathrm{~d}, J=13.0 \mathrm{~Hz}, 1 \mathrm{H}), 3.84(\mathrm{~d}, J$ $=9.1 \mathrm{~Hz}, 1 \mathrm{H}), 3.71(\mathrm{dd}, J=6.5,0.7 \mathrm{~Hz}, 1 \mathrm{H}), 3.24(\mathrm{dd}, J=16.1$, $6.5 \mathrm{~Hz}, 1 \mathrm{H}), 3.01$ (dd, $J=13.2,7.2 \mathrm{~Hz}, 1 \mathrm{H}), 2.57-2.24(\mathrm{~m}, 6 \mathrm{H})$, $2.23(\mathrm{~s}, 3 \mathrm{H}), 1.98(\mathrm{~s}, 3 \mathrm{H}), 1.77-1.72(\mathrm{~m}, 3 \mathrm{H}), 1.61(\mathrm{~d}, J=1.0$ $\mathrm{Hz}, 3 \mathrm{H}) ;{ }^{13} \mathrm{C}\left\{{ }^{1} \mathrm{H}\right\}$ NMR $\left(\mathrm{CDCl}_{3}, 101 \mathrm{MHz}\right) \delta 170.2,170.0$, 168.1, 156.0, 152.4, 146.7, 122.2, 115.1, 110.6, 80.9, 73.1, 69.7, 53.2, 46.3, 42.8, 39.7, 34.2, 30.5, 23.6, 21.9, 21.7, 21.1, 21.0; IR (Neat Film, NaCl) 2925, 1740, 1615, 1440, 1372, 1241, 1204, $1153,1118,1043,968,934,899,792,754 \mathrm{~cm}^{-1}$; HRMS (FAB+) $m / z$ calc'd for $\mathrm{C}_{23} \mathrm{H}_{27} \mathrm{O}_{7}[\mathrm{M}+\mathrm{H}]^{+}$: 415.1757, found 415.1737; $[\alpha]_{\mathrm{D}}^{25.0}+241.6^{\circ}\left(c 0.100, \mathrm{CHCl}_{3}\right)$.

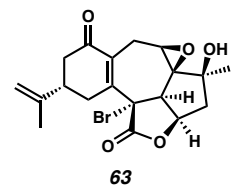

$\left(2 S, 2 \mathrm{a} S, 2 \mathrm{a}^{1} R, 3 \mathrm{a} R, 7 S, 8 \mathrm{~b} S, 10 \mathrm{a} R\right)-8 \mathrm{~b}-\mathrm{bromo}-2-\mathrm{hydroxy}-2-$ methyl-7-(prop-1-en-2-yl)-1,2a $1,4,6,7,8,8 b, 10 a-$ octahydrobenzo[6,7]oxireno[ $\left.2^{\prime}, 3^{\prime}: 3 \mathrm{a}, 4\right]$ azuleno $[1,8-b c]$ furan$5,9(2 \mathrm{H}, 3 \mathrm{a} H)$-dione (63). To a stirred solution of entisoineleganolide A (13, $15 \mathrm{mg}, 0.047 \mathrm{mmol}, 1.00$ equiv) in $\mathrm{CH}_{2} \mathrm{Cl}_{2}(3.0 \mathrm{~mL})$ was added DMAP $(25 \mathrm{mg}, 0.20 \mathrm{mmol}, 4.36$ equiv) as a solid in one portion. After 2 minutes, the reaction mixture had become a completely homogenous pale yellow solution, and TBSCl (70 mg, $0.46 \mathrm{mmol}, 9.79$ equiv) was added as a solution in $\mathrm{CH}_{2} \mathrm{Cl}_{2}(0.7 \mathrm{~mL})$ quickly dropwise over 2 minutes. After $2 \mathrm{~h}$, the consumption of starting material was complete as determined by TLC (1:4 EtOAc: $\mathrm{CH}_{2} \mathrm{Cl}_{2}$ eluent). The reaction was quenched by the addition of $\mathrm{Et}_{3} \mathrm{~N}(0.30 \mathrm{~mL}, 2.15 \mathrm{mmol}$, 45.7 equiv) in hexanes $(3.0 \mathrm{~mL})$ with stirring. After 5 minutes, the white suspension was loaded directly onto a silica gel column and purified by silica gel column chromatography $30 \%$ EtOAc with $0.5 \% \mathrm{Et}_{3} \mathrm{~N}$ in hexanes eluent, silica gel deactivated by wet loading with eluent prior to purification) to provide intermediate dienol ether $\mathbf{5 9}$ (20 mg, >99\% yield), which was immediately carried on to the next transformation.

To a clear, colorless stirred solution of a portion of dienol ether 59 ( $5 \mathrm{mg}, 0.011 \mathrm{mmol}, 1.00$ equiv) in $\mathrm{CH}_{2} \mathrm{Cl}_{2}(0.6 \mathrm{~mL})$ at $78{ }^{\circ} \mathrm{C}(i$-PrOH/dry ice bath) was added $N$-bromosuccinimide (NBS, $3.4 \mathrm{mg}, 0.019 \mathrm{mmol}, 1.73$ equiv) as a solid in a single portion to provide a homogenous, colorless reaction mixture. After $2 \mathrm{~h}$, the consumption of starting material was complete as determined by TLC (1:1 EtOAc:Hexanes eluent). The reaction was quenched by the addition of saturated aqueous $\mathrm{Na}_{2} \mathrm{~S}_{2} \mathrm{O}_{3}(0.5$ $\mathrm{mL}$ ) and the reaction vessel was immediately removed from the cooling bath and allowed to warm to ambient temperature (ca. 23 $\left.{ }^{\circ} \mathrm{C}\right)$. The biphasic solution was then diluted with $\mathrm{CH}_{2} \mathrm{Cl}_{2}(4.0$ $\mathrm{mL}$ ) and poured onto saturated aqueous $\mathrm{NaHCO}_{3}(3.0 \mathrm{~mL})$. The organics were separated and the aqueous was extracted with 
$\mathrm{CH}_{2} \mathrm{Cl}_{2}(3 \times 2 \mathrm{~mL})$. The combined organics were dried over $\mathrm{MgSO}_{4}$, filtered, and concentrated in vacuo. The crude white solid was purified by silica gel column chromatography $(50 \%$ EtOAc in hexanes eluent) to afford $\alpha$-bromolactone 63 (4 mg, $80 \%$ yield) as an amorphous white solid: $\mathrm{R}_{f}=0.32(1: 1$ EtOAc:Hexanes eluent); ${ }^{1} \mathrm{H}$ NMR $\left(\mathrm{CDCl}_{3}, 400 \mathrm{MHz}\right) \delta 5.18$ (ddd, $J=5.1,4.2,2.2 \mathrm{~Hz}, 1 \mathrm{H}), 4.88-4.83(\mathrm{~m}, 1 \mathrm{H}), 4.77$ (q, $J=$ $1.0 \mathrm{~Hz}, 1 \mathrm{H}), 3.96(\mathrm{dd}, J=17.3,6.7 \mathrm{~Hz}, 1 \mathrm{H}), 3.68(\mathrm{ddt}, J=16.8$, $3.5,1.9 \mathrm{~Hz}, 1 \mathrm{H}), 3.62(\mathrm{~d}, J=4.2 \mathrm{~Hz}, 1 \mathrm{H}), 3.36(\mathrm{~d}, J=6.6 \mathrm{~Hz}$, $1 \mathrm{H}), 2.80-2.65$ (m, 2H), 2.62-2.49 (m, 1H), 2.49-2.42 (m, 2H), 2.42-2.37 (m, 2H), 2.37-2.32 (m, 1H), $1.82(\mathrm{~s}, 3 \mathrm{H}), 1.35(\mathrm{~s}$, $3 \mathrm{H}) ;{ }^{13} \mathrm{C}\left\{{ }^{1} \mathrm{H}\right\}$ NMR $\left(\mathrm{CDCl}_{3}, 101 \mathrm{MHz}\right) \delta 198.8,169.3,150.2$, $146.4,129.0,110.8,80.7,75.1,69.8,62.1,54.3,52.4,45.1,43.1$, 40.6, 35.6, 27.4, 21.1, 20.8; IR (Neat Film, NaCl) 3508, 2965, $1774,1668,1443,1367,1260,1168,1100,973,894,789,759$ $\mathrm{cm}^{-1}$; HRMS (FAB+) $\mathrm{m} / \mathrm{z}$ calc'd for $\mathrm{C}_{19} \mathrm{H}_{22} \mathrm{O}_{5}{ }^{81} \mathrm{Br}[\mathrm{M}+\mathrm{H}]^{+}$: 411.0630, found 411.0634; $[\alpha]_{\mathrm{D}}^{25.0}+141.1^{\circ}\left(c 0.200, \mathrm{CHCl}_{3}\right)$.

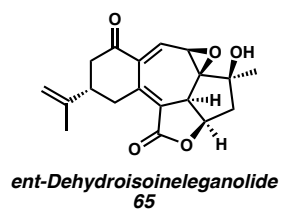

$\left(2 S, 2 \mathrm{a} S, 2 \mathrm{a}^{1} R, 3 \mathrm{a} R, 7 S, 10 \mathrm{a} R\right)-2-h y d r o x y-2-m e t h y l-7-(p r o p-1-$ en-2-yl)-1,2a ${ }^{1}, 6,7,8,10 a-$

hexahydrobenzo $[6,7]$ oxireno $\left[2^{\prime}, 3^{\prime}: 3 a, 4\right]$ azuleno $[1,8-b c]$ furan$5,9(2 H, 3 a H)$-dione (ent-Dehydroisoineleganolide, 65). To a stirred solution of ent-isoineleganolide A $(\mathbf{1 3}, 46 \mathrm{mg}, 0.14 \mathrm{mmol}$, 1.00 equiv) in $\mathrm{CH}_{2} \mathrm{Cl}_{2}(6.0 \mathrm{~mL})$ was added DMAP ( $85 \mathrm{mg}, 0.70$ mmol, 5.00 equiv) as a solid in one portion. After 2 minutes, the reaction mixture had become a completely homogenous pale yellow solution, and TBSCl $(210 \mathrm{mg}, 1.39 \mathrm{mmol}, 10.0$ equiv) was added as a solution in $\mathrm{CH}_{2} \mathrm{Cl}_{2}(2.1 \mathrm{~mL})$ quickly dropwise over 2 minutes. After $2 \mathrm{~h}$, the consumption of starting material was complete as determined by TLC (1:4 EtOAc: $\mathrm{CH}_{2} \mathrm{Cl}_{2}$ eluent). The reaction was quenched by the addition of $\mathrm{Et}_{3} \mathrm{~N}(0.97 \mathrm{~mL}, 7.0$ mmol, 50.0 equiv) in hexanes $(6.0 \mathrm{~mL})$ with stirring. After 5 minutes, the white suspension was loaded directly onto a silica gel column and purified by silica gel column chromatography (30\% EtOAc with $0.5 \% \mathrm{Et}_{3} \mathrm{~N}$ in hexanes eluent, silica gel deactivated by wet loading with eluent prior to purification) to provide intermediate dienol ether 59 (62 $\mathrm{mg},>99 \%$ yield), which was immediately carried on to the next transformation.

To a clear, colorless stirred solution to dienol ether $\mathbf{5 9}(62 \mathrm{mg}$, $0.14 \mathrm{mmol}, 1.00$ equiv) in DMSO $(3.0 \mathrm{~mL})$ was added $\mathrm{Pd}(\mathrm{OAc})_{2}$ ( $35 \mathrm{mg}, 0.016 \mathrm{mmol}, 1.14$ equiv) as a solid in a single portion. After $2 \mathrm{~h}$, the golden yellow homogeneous reaction mixture had become dark brown and the consumption of starting material was complete as determined by TLC (3:7 EtOAc:Hexanes eluent). The reaction was then diluted with EtOAc $(10 \mathrm{~mL})$ and poured onto $\mathrm{H}_{2} \mathrm{O}(30 \mathrm{~mL})$. The organics were separated and the aqueous was extracted with EtOAc $(3 \times 20 \mathrm{~mL})$. The combined organics were washed with $\mathrm{H}_{2} \mathrm{O}(30 \mathrm{~mL})$, dried over $\mathrm{MgSO}_{4}$, filtered through a pad of silica gel (EtOAc eluent), and concentrated in vacuo. The crude brown solid was purified by silica gel column chromatography (55\% EtOAc in hexanes eluent) to afford ent-dehydroisoineleganolide $(\mathbf{6 5}, 27 \mathrm{mg}, 60 \%$ yield) as an amorphous white solid: $\mathrm{R}_{f}=0.25$ (1:1 EtOAc:Hexanes eluent); ${ }^{1} \mathrm{H}$ NMR $\left(\mathrm{CDCl}_{3}, 400 \mathrm{MHz}\right) \delta 7.19(\mathrm{~d}, J=4.6 \mathrm{~Hz}, 1 \mathrm{H}), 4.98$ (ddd, $J=8.4,7.5,6.8 \mathrm{~Hz}, 1 \mathrm{H}), 4.83$ (h, $J=1.5 \mathrm{~Hz}, 1 \mathrm{H}), 4.72-$ $4.65(\mathrm{~m}, 1 \mathrm{H}), 3.72(\mathrm{~d}, J=4.6 \mathrm{~Hz}, 1 \mathrm{H}), 3.59-3.47(\mathrm{~m}, 2 \mathrm{H}), 3.18$ $3.05(\mathrm{~m}, 1 \mathrm{H}), 2.73-2.60(\mathrm{~m}, 3 \mathrm{H}), 2.56-2.46(\mathrm{~m}, 1 \mathrm{H}), 2.15$ (d, $J=$ $1.0 \mathrm{~Hz}, 1 \mathrm{H}), 1.87$ (ddd, $J=13.7,7.0,1.2 \mathrm{~Hz}, 1 \mathrm{H}), 1.79$ (dt, $J=$ $1.2,0.6 \mathrm{~Hz}, 3 \mathrm{H}), 1.41(\mathrm{t}, J=1.0 \mathrm{~Hz}, 3 \mathrm{H}) ;{ }^{13} \mathrm{C}\left\{{ }^{1} \mathrm{H}\right\}$ NMR $\left(\mathrm{CDCl}_{3}, 101 \mathrm{MHz}\right) \delta 197.5,169.5,146.3,145.9,140.5,137.7$,
119.6, 111.5, 94.9, 74.6, 74.5, 52.1, 47.1, 44.0, 43.7, 37.9, 31.7, 23.8, 21.3; IR (Neat Film, NaCl) 3459, 2923, 2852, 1742, 1706, 1634, 1449, 1377, 1259, 1173, 1090, 1026, $798 \mathrm{~cm}^{-1}$; HRMS $(\mathrm{FAB}+) \mathrm{m} / z$ calc'd for $\mathrm{C}_{19} \mathrm{H}_{21} \mathrm{O}_{5}[\mathrm{M}+\mathrm{H}]^{+}:$329.1389, found $329.1373 ;[\alpha]_{\mathrm{D}}^{25.0}-40.2^{\circ}\left(c 0.075, \mathrm{CHCl}_{3}\right)$.

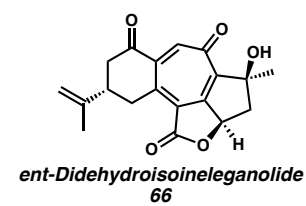

$(2 \mathrm{a} R, 4 S, 9 S)$-4-hydroxy-4-methyl-9-(prop-1-en-2-yl)2a,3,4,8,9,10-hexahydro- $1 H$-benzo[6,7]azuleno[1,8-bc]furan1,5,7-trione (ent-Didehydroisoineleganolide, 66). To a reaction vessel in a nitrogen-filled glovebox was charged $\mathrm{Yb}(\mathrm{OTf})_{3}(8$ $\mathrm{mg}, 0.013 \mathrm{mmol}, 1.08$ equiv). The reaction vessel was sealed, removed from the glovebox, and introduced to an argon atmosphere. To the white solid was added ent-dehydroisoineleganolide $(\mathbf{6 5}, 4 \mathrm{mg}, 0.012 \mathrm{mmol}, 1.00$ equiv) as a solution in toluene (1.0 $\mathrm{mL}$ ) with stirring. The white suspension was then introduced to a preheated $50{ }^{\circ} \mathrm{C}$ bath. After $7 \mathrm{~h}$, the reaction was further heated to $80^{\circ} \mathrm{C}$. After an additional $17 \mathrm{~h}$, the reaction was heated to 100 ${ }^{\circ} \mathrm{C}$. After $11 \mathrm{~h}$, the consumption of starting material was complete as determined by TLC (1:1 EtOAc:Hexanes eluent). The golden yellow heterogeneous reaction mixture was removed from the heating bath and allowed to cool to ambient temperature (ca. $23{ }^{\circ} \mathrm{C}$ ). The reaction was then concentrated in vacuo. The crude golden brown solid was purified by silica gel column chromatography ( $40 \%$ EtOAc in hexanes eluent) to provide entdidehydroisoineleganolide (66, $3 \mathrm{mg}, 75 \%$ yield) as an amorphous white solid: $\mathrm{R}_{f}=0.09$ (3:7 EtOAc:Hexanes eluent); ${ }^{1} \mathrm{H}$ NMR $\left(\mathrm{CDCl}_{3}, 400 \mathrm{MHz}\right) \delta 8.85(\mathrm{~s}, 1 \mathrm{H}), 5.54(\mathrm{dd}, J=12.8,5.5$ $\mathrm{Hz}, 1 \mathrm{H}), 4.94-4.91(\mathrm{~m}, 1 \mathrm{H}), 4.86(\mathrm{dd}, J=1.8,0.9 \mathrm{~Hz}, 1 \mathrm{H}), 3.95$ (ddd, $J=18.4,4.0,2.0 \mathrm{~Hz}, 1 \mathrm{H}), 3.57(\mathrm{~s}, 1 \mathrm{H}), 3.18$ (dd, $J=18.5$, $10.2 \mathrm{~Hz}, 1 \mathrm{H}), 2.99-2.80(\mathrm{~m}, 3 \mathrm{H}), 2.72(\mathrm{dd}, J=16.0,11.7 \mathrm{~Hz}$, $1 \mathrm{H}), 2.20(\mathrm{t}, J=12.3 \mathrm{~Hz}, 1 \mathrm{H}), 1.89-1.79(\mathrm{~m}, 3 \mathrm{H}), 1.59(\mathrm{~s}, 3 \mathrm{H})$; ${ }^{13} \mathrm{C}\left\{{ }^{1} \mathrm{H}\right\}$ NMR $\left(\mathrm{CDCl}_{3}, 101 \mathrm{MHz}\right) \delta 197.4,195.4,168.1,158.5$, 151.0, 145.3, 135.9, 131.7, 124.6, 123.8, 112.2, 75.2, 73.8, 43.8, 42.6, 41.0, 30.4, 25.7, 20.8; IR (Neat Film, NaCl) 3366, 2923, 2853, 1775, 1692, 1603, 1441, 1332, 1261, 1202, 1090, 1046, 988, 891, $801 \mathrm{~cm}^{-1}$; HRMS (ES+) $\mathrm{m} / z$ calc'd for $\mathrm{C}_{19} \mathrm{H}_{19} \mathrm{O}_{5}$ $[\mathrm{M}+\mathrm{H}]^{+}: 327.1232$, found $327.1236 ;[\alpha]_{\mathrm{D}}^{25.0}+22.7^{\circ}$ (c 0.150, $\mathrm{CHCl}_{3}$ ).

\section{Supporting Information}

The Supporting Information is available free of charge on the ACS Publications website.

${ }^{1} \mathrm{H}$ NMR, ${ }^{13} \mathrm{C}$ NMR, and IR spectra (PDF)

Computational Procedures (PDF)

$\mathrm{X}$-ray crystallographic data for epoxide $\mathbf{1 1}$ (CIF)

$\mathrm{X}$-ray crystallographic data for $2 \mathrm{H}$-ent-ineleganolide $(\mathbf{8}, \mathrm{CIF})$

$\mathrm{X}$-ray crystallographic data for diketone $\mathbf{1 6}$ (CIF)

\section{AUTHOR INFORMATION}

\section{Corresponding Author}

*stoltz@caltech.edu

Notes

The authors declare no competing financial interests.

\section{ACKNOWLEDGMENT}


The authors wish to thank the NIH-NIGMS (R01GM080269), Amgen, the Gordon and Betty Moore Foundation, and Caltech for financial support and Eli Lilly \& Co. for assistance with biological activity screening. Additionally, the authors gratefully acknowledge Larry Henling and Dr. Michael Takase (Caltech) for X-ray crystallographic structural determination, Dr. Mona Shahgholi and Naseem Torian (Caltech) for mass spectrometry assistance, and Dr. David VanderVelde (Caltech) for NMR experimental assistance and helpful discussion. Additionally, Dr. Jeffrey C. Holder, Dr. Corey M. Reeves, Prof. Hosea M. Nelson, Dr. Jonny R. Gordon, Dr. Pamela M. Tadross, and Beau P. Pritchett (Caltech) are thanked helpful discussion. R.A.C. gratefully acknowledges the support of this work provided by a fellowship from the National Cancer Institute of the National Institutes of Health (NIH) under Award Number F31A17435. J.L.R. thanks the California Tobacco-Related Disease Research Program of the University of California, Grant Number 14DT-0004 for a predoctoral fellowship. A.C.J. thanks the NIH for the support of this work provided by a postdoctoral fellowship (Award Number F32GM082000).

\section{REFERENCES}

1. (a) Villa, F. A.; Gerwick, L. Marine Natural Product Drug Discovery: Leads for Treatment of Inflammation, Cancer, Infections, and Neurological Disorders. Immunopharmacol. Immunotoxicol. 2010, 32, 228-237. (b) Cragg, G. M.; Newman, D. J. Anticancer drug discovery and development from natural products. In Bioactive Natural Products: Detection, Isolation, and Structural Determination; Colegate, S. M., Molyneux, R. J., Eds.; CRC Press: Boca Roton, 2008; pp. 323-370. (c) Newman, D. J.; Cragg, G. M.; Snader, K. M. The Influence of Natural Products Upon Drug Discovery. Nat. Prod. Rep. 2000, 17, 215-234. (d) Grabley, S.; Thiericke, R. Bioactive Agents from Natural Sources: Trends in Discovery and Application. Adv. Biochem. Eng. Biotechnol. 1999, 64, 101-154. (e) Cragg, G. M. Paclitaxel (Taxol): A Success Story with Valuable Lessons for Natural Product Drug Discovery and Development. Med. Res. Rev. 1998, $18,315-331$.

2. (a) Jones, B.; Kazlauskas, R. J. Natural Product Biosynthesis: The Road to L. Nature Chem. 2015, 7, 11-12. (b) Brown, D. G.; Lister, T.; May-Dracka, T. L. New Natural Products as New Leads for Antibacterial Drug Discovery. Biorg. Med. Chem. Lett. 2014, 24, 413-418. (c) Von Nussbaum, F.; Brands, M.; Hinzen, B.; Weigand, S.; Häbich, D. Antibacterial Natural Products in Medicinal Chemistry-Exodus or Revival? Angew. Chem., Int. Ed. 2006, 45, 5072-5129.

3. (a) Choi, D.-Y.; Choi, H. Natural Products From Marine Organisms with Neuroprotective Activity in the Experimental Models of Alzheimer's Disease, Parkinson's Disease and Ischemic Brain Stroke: Their Molecular Targets and Action Mechanisms. Arch. Pharm. Res. 2015, 38, 139-170. (b) Fang, L.; Gou, S.; Fang, X.; Cheng, L.; Fleck, C. Current Progresses of Novel Natural Products and Their Derivatives/ Analogs as Anti-Alzheimer Candidates: an Update. Mini Rev. Med. Chem. 2013, 13, 870-887. (c) Chen, X.; Decker, M. MultiTarget Compounds Acting in the Central Nervous System Designed From Natural Products. Curr. Med. Chem. 2013, 20, 1673-1685. (d) Magrone, T.; Marzulli, G.; Jirillo, E. Immunopathogenesis of Neurodegenerative Diseases: Current Therapeutic Models of Neuroprotection with Special Reference to Natural Products. Curr. Pharm. Des. 2012, 18, 34-42.

4. (a) Qui, Y.; Gao, S. Trends in Applying C-H Oxidation to the Total Synthesis of Natural Products. Nat. Prod. Rep. 2016, 33, 562581. (b) McDonald, B. R.; Scheidt, K. A. Pyranone Natural Products as Inspirations for Catalytic Reaction Discovery and Development. Acc. Chem. Res. 2015, 48, 1172-1183. (c) Behenna, D. C.; Stoltz, B. M. Natural Products as Inspiration for Reaction Development: Catalytic Enantioselective Decarboxylative Reactions of Prochiral Enolate Equivalents. Top. Organomet. Chem. 2013, 44, 281-313. (d) Mohr, J. T.; Krout, M. R.; Stoltz, B. M. Natural Products as Inspiration for the Development of Asymmetric Catalysis. Nature 2008, 455, 323-332.
5. (a) Li, Y.; Pattenden, G. Perspectives on the Structural and Biosynthetic Interrelationships Between Oxygenated Furanocembranoids and Their Polycyclic Congeners Found in Corals. Nat. Prod. Rep. 2011, 28, 1269-1310. (b) Li, Y.; Pattenden, G. Novel Macrocyclic and Polycyclic Norcembranoid Diterpenes from Sinularia Species of Soft Coral: Structural Relationships and Biosynthetic Speculations. Nat. Prod. Rep. 2011, 28, 429-440. (c) Montaser, R.; Luesch, H. Marine Natural Products: a New Wave of Drugs? Future Med. Chem. 2011, 3, 1475-1489. (d) Berrue, F.; Kerr, R. G. Diterpenes from Gorgonian Corals. Nat. Prod. Rep. 2009, 26, 681-710. (e) Roethle, P. A.; Trauner, D. The Chemistry of Marine Furanocembranoids, Pseudopteranes, Gersolanes, and Related Natural Products. Nat. Prod. Rep. 2008, 25, 298-317. (f) Kamel, H. N.; Slattery, M. Terpenoids of Sinularia: Chemistry and Biomedical Applications. Pharm. Biol. 2005, 43, 253-269. (g) Rodríguez, A. D. The Natural Products Chemistry of West Indian Gorgonian Octocorals. Tetrahedron 1995, 51, 4571-4618. (h) Tius, M. A. Synthesis of Cembranes and Cembranolides. Chem. Rev. 1988, 88, 719-732.

6. (a) Huang, C.-Y.; Tseng, Y.-J.; Chokkalingam, U.; Hwang, T.-L.; Hsu, C.-H.; Dai, C.-F.; Sung, P.-J.; Sheu, J.-H. Bioactive Isoprenoid-Derived Natural Products from a Dongsha Atoll Soft Coral Sinularia erecta. J. Nat. Prod. 2016, 79, 1339-1346. (b) Hegazy, M.E. F.; Mohamed, T. A.; Elshamy, A. I.; Al-Hammady, M. A.; Ohta, S.; Paré, P. W. Casbane Diterpenes from Red Sea Coral Sinularia polydactyla. Molecules 2016, 21, 308. (c) Lillsunde, K.-E.; Festa, C.; Adel, H.; de Marino, S.; Lombardi, V.; Tilvi, S.; Nawrot, D.; Zampella, A.; D'Souza, L.; D'Auria, M.; Tammela, P. Bioactive Cembrane Derivatives from the Indian Ocean Soft Coral, Sinularia kavarattiensis. Marine Drugs 2014, 12, 4045-4068. (d) Thao, N. P.; Nam, N. H.; Cuong, N. X.; Luyen, B. T. T.; Tai, B. H.; Kim, J. E.; Song, S. B.; Kiem, P. V.; Minh, C. V.; Kim, Y. H. Inhibition of NF-кB Transcriptional Activation in HepG2 Cells by Diterpenoids from the Soft Coral Sinularia maxima. Arch. Pharm. Res. 2014, 37, 706-712. (e) Thao, N. P.; Nam, N. H.; Cuong, N. X.; Quang, T. H.; Tung, P. T.; Dat, L. D.; Chae, D.; Kim, S.; Koh, Y.-S.; Kiem, P. V.; Minh, C. V.; Kim, Y. H. Anti-inflammatory Norditerpenoids from the Soft Coral Sinularia maxima. Bioorg. Med. Chem. Lett. 2013, 23, 228-231. (f) Cheng, S.Y.; Chuang, C.-T.; Wen, Z.-H.; Wang, S.-K.; Chiou, S.-F.; Hsu, C.H.; Dai, C.-F.; Duh, C.-Y. Bioactive Norditerpenoids from the Soft Coral Sinularia gyrosa. Bioorg. Med. Chem. 2010, 18, 3379-3386. (g) Tseng, Y.-J.; Ahmed, A. F.; Hsu, C.-H.; Su, J.-H.; Dai, C.-F.; Sheu, J.-H. New Norcembranoids from the Soft Coral Sinularia lochmodes. J. Chinese Chem. Soc. 2007, 54, 1041-1044. (h) Ahmed, A. F.; Shiue, R.-T.; Wang, G.-H.; Dai, C.-F.; Kuo, Y.-H.; Sheu, J.-H. Five Novel Norcembranoids from Sinularia leptoclados and S. parva. Tetrahedron 2003, 59, 7337-7344. (i) Sheu, J.-H.; Ahmed, A. F.; Shiue, R.T.; Dai, C.-F.; Kuo, Y.-H. Scabrolides A-D, Four New Norditerpenoids Isolated from the Soft Coral Sinularia scabra. J. Nat. Prod. 2002, 65, 1904-1908. (j) Duh, C.-Y.; Wang, S.-K.; Chia, M.-C.; Chiang, M. Y. A Novel Cytotoxic Norditerpenoid from the Formosan Soft Coral Sinularia inelegans. Tetrahedron Lett. 1999, 40, 60336035 .

7. Radhika, P.; Subba Rao, P. V.; Anjaneyulu, V.; Asolkar, R. N.; Laatsch, H. Horiolide, a Novel Norditerpenoid from Indian Ocean Soft Coral of the Genus Sinularia. J. Nat. Prod. 2002, 65, 737-739.

8. For attempts by others toward the total synthesis of ineleganolide, see: (a) Horn, E. J.; Silverston, J. S.; Vanderwal, C. D. A Failed Late-Stage Epimerization Thwarts an Approach to Ineleganolide. J. Org. Chem. 2016, 81, 1819-1838. (b) Horn, E. J. Studies Toward the Synthesis of Ineleganolide. Ph.D. dissertation, University of California at Irvine, Irvine, CA, 2014. (c) Liu, G. Beta-lactones as Synthetic Vehicles in Natural Product Synthesis: Total Synthesis of Schulzeines B \& C and Omphadiol, and Studies Toward the Total Syntheses of Scabrolides A \& B and Sinulochmodin C. Ph.D. dissertation, Texas A\&M University, College Station, Texas, 2011. (d) Ueda, Y.; Abe, H.; Iguchi, K.; Ito, H. Synthetic Study of Yonarolide: Stereoselective Construction of the Tricyclic Core. Tetrahedron Lett. 2011, 52, 3379-3381. (e) Tang, F. Intramolecular Anodic Olefin Coupling Reactions: Probing the Effect of the Radical Cation Polarization on Carbon-Carbon Bond Formation. An Approach to the Total Synthesis of Ineleganolide. Ph.D. dissertation, Washington University 
in St. Louis, St. Louis, Missouri, 2009. (f) Tang, F.; Moeller, K. D. Anodic Oxidations and Polarity: Exploring the Chemistry of Olefinic Radical Cations. Tetrahedron 2009, 65, 10863-10875. (g) Liu, G.; Romo, D. Unified Synthetic Strategy Toward Scabrolides, Sinulochmodin, and Ineleganolide via Transannular CH Insertions and Aldol Condensations. Abstracts of Papers, 237th American Chemical Society National Meeting, Salt Lake City, UT, Mar 22-26, 2009; American Chemical Society, 2009; ORGN-083. (h) Tang, F.; Moeller, K. D. Intramolecular Anodic Olefin Coupling Reactions: Probing the Effect of the Radical Cation Polarization on Carbon-Carbon Bond Formation. J. Am. Chem. Soc. 2007, 129, 12414-12415. (i) O'Connell, C. E. Ph.D. dissertation, Queen's University of Belfast, Belfast, Northern Ireland, U.K., 2006. (j) O'Connell, C. E.; Frontier, A. J. Abstracts of Papers, 32nd Northeast Regional Meeting of the American Chemical Society, Rochester, NY, Oct 31-Nov 3, 2004; American Chemical Society, 2004; GEN-088.

9. The biosynthetic speculations concerning the formation of ineleganolide (1) from a macrocyclic precursor natural product through a series of anionic intramolecular cyclizations were investigated and confirmed by the biomimetic semisynthesis, see: Li, Y.; Pattenden, G. Biomimetic Syntheses of Ineleganolide and Sinulochmodin C from 5Episiuleptolide via Sequences of Transannular Michael Reactions. Tetrahedron 2011, 67, 10045-10052.

10. Craig, R. A., II; Roizen, J. L.; Smith, R. C.; Jones, A. C.; Virgil, S. C.; Stoltz, B. M. Enantioselective, Convergent Synthesis of the Ineleganolide Core by a Tandem Annulation Cascade. Chem. Sci. 2017, 8, 507-514; 2019, 10, 1254-1255.

11. For full details of the synthetic program, please see the two papers preceding this article, including: (a) Craig, R. A., II; Smith, R. C.; Roizen, J. L.; Jones, A. C.; Virgil, S. C.; Stoltz, B. M. The Development of a Unified Enantioselective, Convergent Synthetic Approach Toward the Furanobutenolide-Derived Polycyclic Norcembranoid Diterpenes: Asymmetric Formation of the Polycyclic Norditerpenoid Carbocyclic Core by Tandem Annulation Cascade. $J$. Org. Chem. 2018, 83, 3467-3485. (b) Roizen, J. L.; Jones, A. C.; Smith, R. C.; Virgil, S. C.; Stoltz, B. M. Model Studies to Access the $[6,7,5,5]$-Core of Ineleganolide Using Tandem TranslactonizationCope or Cyclopropanation-Cope Rearrangements as Key Steps. $J$. Org. Chem. 2017, 82, 13051-13067.

12. In order to be consistent with the initial communication of this research program, epoxide $\mathbf{1 3}$ has been named entisoineleganolide A, enone 5 has been named ent-isoineleganolide B, and oxetane 70 has been named ent-isoineleganolide C. See references 8 and 9 for full details.

13. (a) Ly, T. W.; Liao, J.-H.; Shia, K.-S.; Liu, H.-J. A Highly Effective Diels-Alder Approach to cis-Clerodane Natural Products: First Total Synthesis of Solidago Alcohol. Synthesis 2004, 271-275. (b) Paisdor, B.; Kuck, D. Benzoannulated centropolyquinones. 8 Synthesis and Reactions of 9,10,11-Triptindantrione and Some Other Functionalized Tribenzo[3.3.3]propellanes $\quad(9 \mathrm{H}, 10 \mathrm{H}-4 \mathrm{~b}, 9 \mathrm{a}-$ ([1,2]Benzenomethano)indeno[1,2-a]indenes). J. Org. Chem. 1991, 56, 4753-4759. (c) Paritosh, D.; Byun, H.-S.; Engel, R. An Improved Direct Oxidation of Alkyl Halides to Aldehydes. Synth. Commun. 1986, 16, 1343-1346. (d) Mancuso, A. J.; Swern, D. Activated Dimethyl Sulfoxide: Useful Reagents for Synthesis. Synthesis 1981, 165185. (e) Kornblum, N.; Jones, W. J.; Anderson, G. J. A New and Selective Method of Oxidation. The Conversion of Alkyl Halides and Alkyl Tosylates to Aldehydes. J. Am. Chem. Soc. 1959, 81, 41134114.

14. (a) Gansäuer, A.; Brändle, G. M Bis(cyclopentadienyl)titanium dichloride: Zinc Metal. In e-EROS Encyclopedia of Reagents for Organic Synthesis. 2012. (b) Jiménez, T.; Campaña, A. G.; Bazdi, B.; Paradas, M.; Arráez-Román, D.; Segura-Carretero, A.; Fernández-Gutiérrez, A.; Oltra, J. E.; Robles, R.; Justicia, J.; Cuerva, J. M. Radical Reduction of Epoxides Using a Titanocene(III)/Water System: Synthesis of $\beta$-Deuterated Alcohols and Their Use as Internal Standards in Food Analysis. Eur. J. Org. Chem. 2010, 4288-4295. (c) Gansäuer, A.; Barchuk, A.; Fielenbach, D. Titanocene-catalyzed Reductive Epoxide Opening: The Quest for Novel Hydrogen Atom Donors. Synthesis 2004, 2567-2573. (d) Gansäuer, A.; Rinker, B. A Comparison of Electron Transfer Reagents in the Reductive Opening of Epoxides: Reasons for the Superiority of Titanocene Based Complexes. Tetrahedron 2002, 58, 7017-7026. (e) Gansäuer, A.; Pierobon, M.; Bluhm, H. Catalytic, Highly Regio- and Chemoselective Generation of Radicals from Epoxides: Titanocene Dichloride as an Electron Transfer Catalyst in Transition Metal Catalyzed Radical Reactions. Angew. Chem., Int. Ed. 1998, 37, 101-103.

15. 1,4-Cyclohexadiene was also screened as a hydrogen atom donor, but was not as effective as the $\mathrm{Cp}_{2} \mathrm{TiCl}$ aquo complex. $\mathrm{Mn}^{0}$ and $\mathrm{Zn}^{0}$ were both screened as reductants.

16. Calculations were performed with Spartan '10 (Wavefunction, Inc., Irvine, CA). The in vacuo equilibrium geometry for each structure was calculated by a series of sequential calculations as follows: Hartree-Fock computation (equilibrium geometry, 3-21G basis set), DFT (equilibrium geometry, B3LYP/6-31G basis set), DFT (energy, B3LYP/6-311+G** basis set), DFT (equilibrium geometry, B3LYP/6-311+G** basis set). The error from these calculations is $\pm 0.23 \mathrm{kcal} / \mathrm{mol}$, thus all energy differences larger than $0.46 \mathrm{kcal} / \mathrm{mol}$ were considered significant. Except for molecular mechanics and semi-empirical models, the calculation methods used in Spartan have been documented in: Shao, Y.; Molnar, L. F.; Jung, Y.; Kussmann, J.; Ochsenfeld, C.; Brown, S. T.; Gilbert, A. T. B.; Slipchenko, L. V.; Levchenko, S. V.; O’Neill, D. P.; DiStasio, Jr., R. A.; Lochan, R. C.; Wang, T.; Beran, G. J. O.; Besley, N. A.; Herbert, J. M.; Lin, C. Y.; Van Voorhis, T.; Chien, S. H.; Sodt, A.; Steele, R. P.; Rassolov, V. A.; Maslen, P. E.; Korambath, P. P.; Adamson, R. D.; Austin, B.; Baker, J.; Byrd, E. F. C.; Dachsel, H.; Doerksen, R. J.; Dreuw, A.; Dunietz, B. D.; Dutoi, A. D.; Furlani, T. R.; Gwaltney, S. R.; Heyden, A.; Hirata, S.; Hsu, C-P.; Kedziora, G.; Khalliulin, R. Z.; Klunzinger, P. Lee, A. M.; Lee, M. S.; Liang, W. Z.; Lotan, I.; Nair, N.; Peters, B.; Proynov, E. I.; Pieniazek, P. A.; Rhee, Y. M.; Ritchie, J.; Rosta, E; Sherrill, C. D.; Simmonett, A. C.; Subotnik, J. E.; Woodcock, III, H. L.; Zhang, W.; Bell, A. T.; Chakraborty, A. K.; Chipman, D. M.; Keil, F. J.; Warshel, A.; Hehre, W. J.; Schaefer, H. F.; Kong, J.; Krylov, A. I.; Gill, P. M. W.; Head-Gordon M. Advances in Methods and Algorithms in a Modern Quantum Chemistry Program Package. Phys. Chem. Chem. Phys. 2006, 8, 3172-3191.

17. (a) Betancor, C.; Freire, R.; Pérez-Martín, I.; Prangé, T.; Suárez, E. Hydrogen Atom Transfer Methodology for the Synthesis of C-22, C-23, and C-25 Stereoisomers of Cephalostatin North 1 Side Chain from Spirostan Sapogenins. Tetrahedron 2005, 61, 2803-2814. (b) Cornella, I.; Sestelo, J. P.; Mouriño, A.; Sarandeses, L. A. Synthesis of New 18-Substituted Analogues of Calcitriol Using a Photochemical Remote Functionalization. J. Org. Chem. 2002, 67, 47074714. (c) Paquette, L. A.; Sun, L.-Q.; Friedrich, D.; Savage, P. B. Total Synthesis of (+)-Epoxydictymene. Application of Alkoxydirected Cyclization to Diterpenoid Construction. J. Am. Chem. Soc. 1997, 119, 8438-8450. (d) Dorta, R. L.; Francisco, C. G.; Hernández, R.; Salazar, J. A.; Suárez, E. Intramolecular Hydrogen Abstraction. (Diacetoxyiodo)benzene, a Useful Teagent for the Temote Fuctionalization of Non-activated Carbon Atoms. J. Chem. Res. (S) 1990, 240241. (e) Concepción, J. I.; Francisco, C. G.; Hernández, R.; Salazar, J. A.; Suárez, E. Intramolecular Hydrogen Abstraction. Iodosobenzene Diacetate, an Efficient and Convenient Reagent for Alkoxy Radical Generation. Tetrahedron Lett. 1984, 25, 1953-1956.

18. Mihailovic, M. L.; Cekovic, Z. Intramolecular Oxidative Cyclization of Alcohols with Lead Tetraacetate. Synthesis 1970, 209224

19. (a) Moriarty, R. M.; Vaid, R. K.; Hopkins, T. E.; Vaid, B. K.; Prakash, O. Hypervalent Iodine Oxidation of 5-Keto Acids and 4,6Diketo Acids with [Hydroxy(tosyloxy)iodo]benzene: Synthesis of Keto- $\gamma$-lactones and Diketo- $\delta$-lactones. Tetrahedron Lett. 1990, 31, 201-204. (b) Koser, G. F.; Relenyi, A. G.; Kalos, A. N.; Rebrovic, L.; Wettach, R. H. One-step Alpha-tosyloxylation of Ketones with [Hydroxy(tosyloxy)iodo]benzene. J. Org. Chem. 1982, 47, 2487-2489.

20. (a) Diao, T.; Stahl, S. S. Synthesis of Cyclic Enones via Direct Palladium-Catalyzed Aerobic Dehydrogenation of Ketones. $J$. Am. Chem. Soc. 2011, 133, 14566-14569. (b) Trost, B. M.; Dong, G.; Vance, J. A. Cyclic 1,2-Diketones as Core Building Blocks: A Strategy for the Total Synthesis of (-)-Terpestacin. Chem. Eur. J. 2010, 16, $6265-6277$. 
21. (a) Nicolaou, K. C.; Montagnon, T.; Baran, P. S.; Zhong, Y. L. Iodine(V) Reagents in Organic Synthesis. Part 4. o-Iodoxybenzoic Acid as a Chemospecific Tool for Single Electron Transfer-Based Oxidation Processes. J. Am. Chem. Soc. 2002, 124, 2245-2258. (b) Nakajima, R.; Ogino, T.; Yokoshima, S.; Fukuyama, T. Total Synthesis of (-)-Mersicarpine. J. Am. Chem. Soc. 2010, 132, 1236-1237.

22. Determined by ${ }^{1} \mathrm{H}$ NMR studies of the crude reaction product.

23. For examples of Saegusa-Ito oxidations within cycloheptanones, see: (a) Pandey, G.; Adate, P. A.; Puranik, V. G. Organocatalytic Dynamic Kinetic Tesolution via Conjugate Addition: Synthesis of Chiral Trans-2,5-dialkylcyclohexanones. Org. Biomol. Chem. 2012, 10, 8260-8267. (b) Ohmori, N. Application of [5+2] Cycloaddition Toward the Functionalized Bicyclo[4.3.1]decane Ring System: Synthetic Study of Phomoidride B (CP-263,114). J. Chem. Soc., Perkin Trans. 1 2002, 755-767. (c) Degrado, S. J.; Mizutani, H.; Hoveyda, A. H. Modular Peptide-Based Phosphine Ligands in Asymmetric Catalysis: Efficient and Enantioselective $\mathrm{Cu}$-Catalyzed Conjugate Additions to Five-, Six-, and Seven-Membered Cyclic Enones. J. Am. Chem. Soc. 2001, 123, 755-756.

24. The relative stereochemistry at carbinol C(3) of tetracycle $\mathbf{1 7}$ was assigned by analogy to the relative stereochemistry of allylic alcohol $\mathbf{2 4}$ and by the observed oxidation of alcohol I to diepoxide II as an inseparable 1:1 mixture of diastereomers as determined by ${ }^{1} \mathrm{H}$ NMR. The directed epoxidation of the dihomoallylic isopropenyl group could only be accomplished with $(S)$-configuration at C(3).

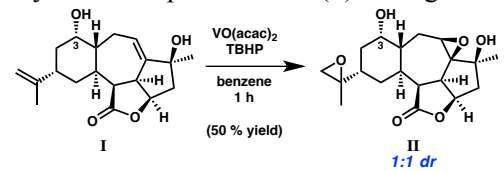

25. The $\mathrm{C}(3)$ configuration of allylic alcohol $\mathbf{2 4}$ was determined by two-dimensional ${ }^{1} \mathrm{H}$ NOE studies and the positive NOE correlation between the methine protons at $\mathrm{C}(1)$ and $\mathrm{C}(3)$.

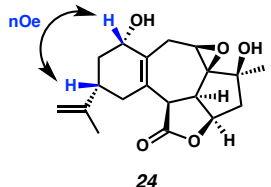

26. Reexposure of isolated silyl ethers $\mathbf{3 0}$ and $\mathbf{3 1}$ to the reaction conditions did not result in any detectable interconversion between the two products.

27. Under titanium(III)-mediated reductive epoxide opening conditions described in Scheme 16, diol 24 failed to furnish any expected product. Rather, dehydration of the secondary alcohol at C(3) was routinely observed under the acidic reaction conditions, as determined by crude ${ }^{1} \mathrm{H}$ NMR.

28. The relative stereochemistry the reduction product was assigned by analogy to ketones $\mathbf{8}$ and $\mathbf{1 6}$, whose configurations were established unambiguously by single crystal X-ray diffraction.

29. Attempts to oxidize enol ether $\mathbf{4 1}$ focused on reaction conditions employing stoichiometric palladium(II) (e.g., $\left.\mathrm{Pd}(\mathrm{OAc})_{2} / \mathrm{DMSO}\right)$ and halogenation reagents (e.g., $\mathrm{NBS} / \mathrm{CH}_{2} \mathrm{Cl}_{2}$ ).

30. In solution, the s-trans conformation of extended polyunsaturated diketone 56 is preferred and was determined by twodimensional ${ }^{1} \mathrm{H}$ NOE studies and the positive NOE correlation between the $\mathrm{C}(16)$ methyl group and the vinyl proton at $\mathrm{C}(2)$.

31. (a) Szostak, M.; Spain, M.; Procter, D. J. Determination of the Effective Redox Potentials of $\mathrm{SmI}_{2}, \mathrm{SmBr}_{2}, \mathrm{SmCl}_{2}$, and their Complexes with Water by Reduction of Aromatic Hydrocarbons. Reduction of Anthracene and Stilbene by Samarium(II) Iodide-Water Complex. J. Org. Chem. 2014, 79, 2522-2537. (b) Egger, J.;
Bretscher, P.; Freigang, S.; Kopf, M.; Carreira, E. M. Synthesis of Epoxyisoprostanes: Effects in Teducing Secretion of Proinflammatory Cytokines IL-6 and IL-12. Angew. Chem., Int. Ed. 2013, 52, 5382-5385. (c) Shoji, M.; Uno, T.; Kakeya, H.; Onose, R.; Shiina, I.; Osada, H.; Hayashi, Y. Enantio- and Diastereoselective Total Synthesis of EI-1941-1, -2, and -3, Inhibitors of Interleukin-1 $\beta$ Converting Enzyme, and Biological Properties of Their Derivatives. J. Org. Chem. 2005, 70, 9905-9915. (d) Yamaguchi, J.; Kakeya, H.; Uno, T.; Shoji, M.; Osada, H.; Hayashi, Y. Determination by Asymmetric Total Synthesis of the Absolute Configuration of Lucilactaene, a Cell-Cycle Inhibitor in p53-Transfected Cancer Cells. Angew. Chem., Int. Ed. 2005, 44, 3110-3115. (e) Ready, J. M.; Reisman, S. E.; Hirata, M.; Weiss, M. M.; Tamaki, K.; Ovaska, T. V.; Wood, J. L. A Mild and Efficient Synthesis of Oxindoles: Progress Towards the Synthesis of Welwitindolinone A Isonitrile. Angew. Chem. Int. Ed. 2004, 43, 1270-1272. (f) Fuchs, J. R.; Mitchell, M. L.; Shabangi, M.; Flowers, R. A. The Effect of Lithium Bromide and Lithium Chloride on the Reactivity of $\mathrm{SmI}_{2}$ in THF. Tetrahedron Lett. 1997, 38, 81578158. (g) Molander, G. A.; Hahn, G. Lanthanides in Organic Synthesis. 2. Reduction of Alpha-heterosubstituted Ketones. J. Org. Chem. 1986, 51, 1135-1138. (h) Molander, G. A.; Hahn, G. Lanthanides in Organic Synthesis. 4. Reduction of $\alpha, \beta$-epoxy Ketones with Samarium Diiodide. A Route to Chiral, Nonracemic Aldols. J. Org. Chem. 1986, 51, 2596-2599.

32. The relative stereochemistry of $\alpha$-bromolactone $\mathbf{6 3}$ was assigned by analogy to the unambiguous assignment of the relative stereochemistry of ent-isoineleganolide A (13) by single crystal X-ray diffraction, see references 8 and 9 .

33. (a) Craig, R. A., II; Smith, R. C.; Pritchett, B. P.; Estipona, B I.; Stoltz, B. M. Preparation of 1,5-Dioxaspiro[5.5] undecan-3-one. Org. Synth. 2016, 93, 210-227. (b) Craig, R. A., II; Roizen, J. L.; Smith, R. C.; Jones, A. C.; Stoltz, B. M. Enantioselective Synthesis of a Hydroxymethyl-cis-1,3-cyclopentenediol Building Block. Org. Lett. 2012, 14, 5716-5719.

34. Biological activity data generated through the Open Innovation Drug Discovery Program (OIDD) and screening data were supplied courtesy of Eli Lilly and Company-used with Lilly's permission. To learn more about the Lilly Open Innovation Drug Discovery program, please visit the program website at https://openinnovation.lilly.com (last accessed on 10-01-2018).

35. A selection of the ineleganoloids were screened against DU145 and A2038 cell viability assays in triplicate, revealing no significant activity. Special, personal thanks to Prof. David Horne and Prof. Sangkil Nam (City of Hope, Duarte, CA) for their assistance in performing these cell viability assays.

36. Pangborn, A. B.; Giardello, M. A.; Grubbs, R. H.; Rosen, R. K.; Timmers, F. J. Safe and Convenient Procedure for Solvent Purification. Organometallics 1996, 15, 1518-1520.

37. DCE was neither distilled, dried, nor degassed prior to use.

38. No HRMS peak for the parent mass of lactol $\mathbf{4 5}$ could be observed, despite screening all instruments and ionization sources available to us. The acid required for most ionization methods is likely causing decomposition of the free lactol. The major mass peaks observed for this compound by ES+ were: 253.1585, 299.1633, 317.1746, 318.1780.

39. No HRMS peak for the parent mass of lactol $\mathbf{4 6}$ could be observed, despite screening all instruments and ionization sources available to us. The acid required for most ionization methods is likely causing decomposition of the free lactol. The major mass peaks observed for this compound by ES+ were: 281.1531, 282.1579, $322.1805,334.2023,335.2060$. 


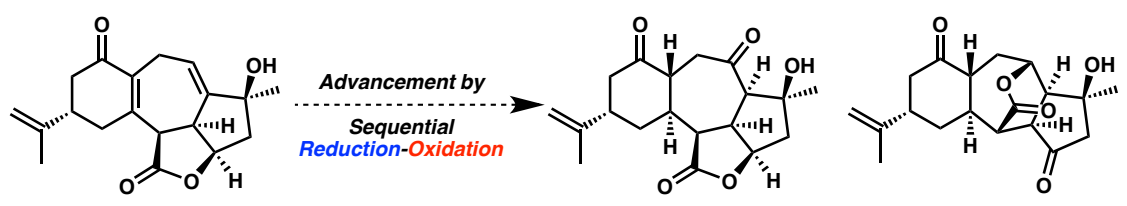

Synthetic Intermediates

Ineleganoloids: Synthetic Ineleganolide Analogs
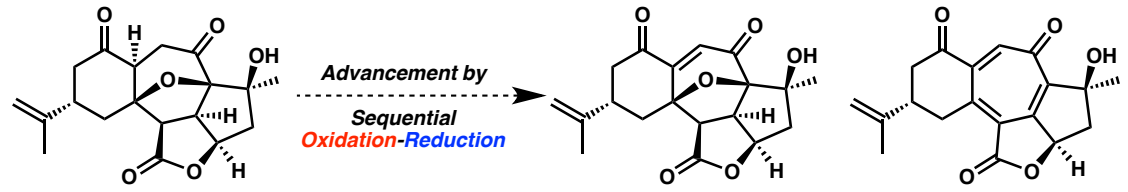